\title{
ATRIBUIÇÕES DA EQUIPE DE ENFERMAGEM DE UNIDADE BÁSICA DE SAÚDE, NA IMPLEMENTAÇÃO DO SISTEMA ÚNICO DE SAÚDE NOS MUNICÍPIOS DE FERRAZ DE VASCONCELOS E TABOÃO DA SERRA
}

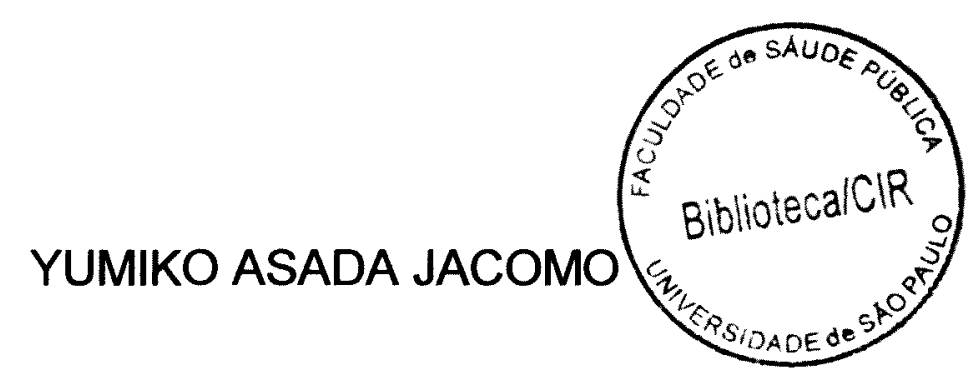

Tese de Doutoramento apresentada ao Departamento de Prática de Saúde Pública da Faculdade de Saúde Pública da Universidade de São Paulo para obtenção do Grau de Doutor.

Área de concentração:

Serviços de Saúde Pública

ORIENTADOR: PROFa. DR ${ }^{a}$. LOURDES DE FREITAS CARVALHO

São Paulo

1999 
Autorizo, exclusivamente para fins acadêmicos e científicos, a reprodução total ou parcial desta tese, por processos fotocopiadores. Assinatura:

Data:

$39194 / 2000$ (oloc) 


\section{AGRADECIMENTOS}

A realização deste trabalho foi possivel graças à ajuda e colaboração de algumas pessoas e Instituições, a quem quero deixar registrado os meus sinceros agradecimentos:

A minha orientadora, Prof. Dra. LOURDES DE FREITAS CARVALHO, pelo privilégio que tive pela sua orientação, marcada pela competência intelectual e estímulo no acompanhamento do meu crescimento acadêmico, compartilhando o seu saber e seu carinho.

A Profa. Dra. ARACY WITT DE PINHO SPINOLA pelo apoio, incentivo e colaboração na discussão metodológica.

Ao Prof. Dr. NELSON IBAÑEZ, ao Prof. Dr. LUCIVALDO N. TAPAJÓS FIGUEIRA e a Prof. Dra. MARIA RITA BERTOLOZZI, pelas valiosas sugestões e críticas para o aprimoramento deste trabalho.

A Profa. Dra. HELENA AKEMI WADA WATANABE pela dedicação e carinho com que acompanhou o trabalho.

As Prefeituras Municipais de Ferraz de Vasconcelos e Taboão da Serra, seus dirigentes e funcionários, pela disponibilidade com que ajudaram no fornecimento de dados, em especial à equipe de enfermagem pela atenção e receptividade.

A todas as pessoas que direta ou indiretamente participaram na realização do presente estudo. 


\section{RESUMO}

Jacomo, YA. Atribuições da equipe de enfermagem de unidade básica de saúde, na implementação do Sistema Único de Saúde nos municípios de Ferraz de Vasconcelos e Taboão da Serra. São Paulo; 1999 [Tese de doutoramento - Faculdade de Saúde Pública da USP].

Foi estudada a composição do pessoal de enfermagem e suas atribuições nas Unidades Básicas de Saúde - UBS, frente às mudanças do sistema de saúde municipal, que apresentam características próprias. $O$ trabalho foi realizado nos municipios de Ferraz de Vasconcelos e Taboão da Serra, que pertencem à região da Grande São Paulo. Os dados foram obtidos através de questionários, individuais e específicos para cada categoria da equipe de enfermagem, composta de enfermeiros e auxiliares de enfermagem. Os municípios em que a pesquisa foi realizada, estão no processo de desenvolvimento do Sistema Único de Saúde, sendo que o pessoal de enfermagem, ainda está por iniciar a sua participação nas transformações do processo político, não estando ainda envolvido no avanço político da localidade; para a compreensão dessas mudanças verificando-se que a sua participação é limitada, muitas vezes pelo quantitativo numérico de enfermeiros e pelas suas atribuições cotidianas. Os resultados permitem concluir que a composição da equipe de enfermagem e as respectivas atribuições, frente às mudanças que vêm ocorrendo nos municípios, e a sua participação no processo é fundamental na prestação de uma assistência integral de qualidade para a sua população e para um desempenho adequado das ações de enfermagem de saúde pública.

Descritores: Equipe de enfermagem. Atribuiçōes da equipe de enfermagem. Enfermagem de saúde pública. Sistema Único de Saúde. 


\section{SUMMARY}

Jacomo YA. Atribuições da equipe de enfermagem de unidade básica de saúde, na implementação do Sistema Único de Saúde nos municípios de Ferraz de Vasconcelos e Taboão da Serra [The nursing personnel activities in a basic health unit, in the development process of the Unit Health System in Ferraz de Vasconcelos and Taboão da Serra]. São Paulo $(\mathrm{Br}) ; 1999$ [Tese de doutorado - Faculdade de Saúde Pública da Universidade de São Paulo].

This study deals with the composition of the nursing personnel from the Basic Health Units according to the development of the municipal health system. The study was developed in two municipalities - Ferraz de Vasconcelos and Taboão da Serra - that belong to the region of São Paulo city. The data were obtained through questionnaires applied to - nurses and auxiliary nursing personnel. The municipalities where the research was done, are in the process of development of the Unit Health System. Nursing is not aware of the political advancement of the locality, because of lack of personnel and the numerous daily activities. The results lead to the conclusion that the composition of the nursing team and the respective roles, according to the changes in the municipalities, as well as their share in the process, are very important for the delivery of a complete health service of quality and for the proper performing of the nursing activities of public health.

Descriptors: Nursing personnel. Nursing personnel activities. Public health nursing. Unit Health System. 


\section{ÍNDICE}

1. INTRODUÇÃO

1.1 Referencial Teórico.................................................... 2

1.1.1 O processo de Implantação da Municipalização ............... 2

1.1.2 Recursos Humanos na Municipalização .......................... 7

1.1.3 Composição da Força de Trabalho da Enfermagem ........ 10

1.1.4 O Trabalho do Enfermeiro .......................................... 15

1.1.5 Os Recursos Humanos em Enfermagem Frente ao SUS. 22

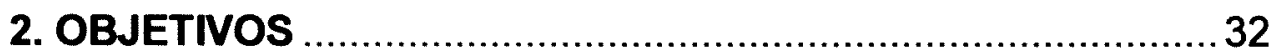

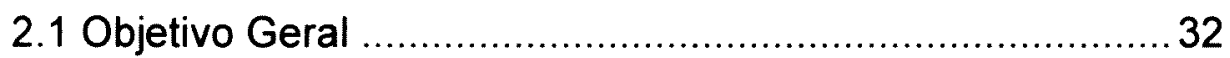

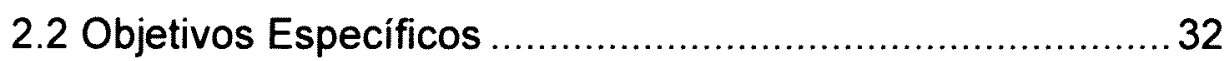

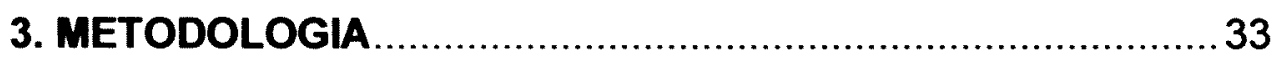

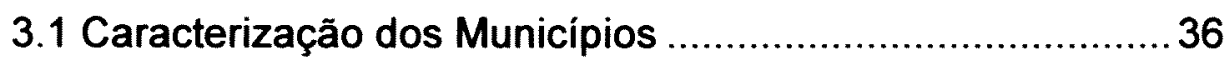

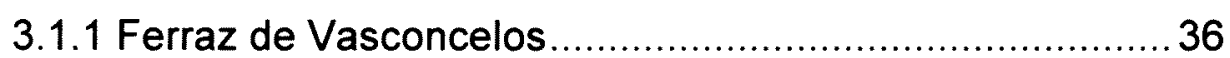

3.1.2 Taboão da Serra ..................................................4 42

3.2 Procedimentos........................................................ 49

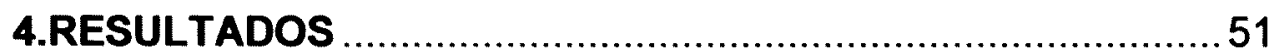

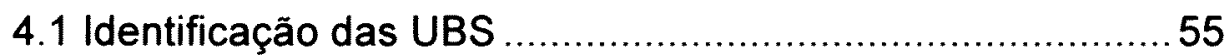

4.2 Identificação dos Enfermeiros de Ferraz de Vasconcelos .. 61

4.2.1 Sobre o Sistema Único de Saúde .................................62

4.2.2 Pessoal de Enfermagem e o Processo de Trabalho ........64

4.2.3 A UBS no Desenvolvimento do Trabalho ........................65

4.3 Identificação dos Enfermeiros de Taboão da Serra ............68

4.3.1 Sobre o Sistema Único de Saúde ................................. 71

4.3.2 Pessoal de Enfermagem e o Processo de Trabalho ........74

4.3.3 A UBS no Desenvolvimento do Trabalho .......................76

4.4 Identificação dos Aux. de Enf. de Ferraz de Vasconcelos .. 79

4.4.1 Trabalho na UBS ..................................................... 80

4.4.2 Sobre os Recursos Humanos ...................................... 82

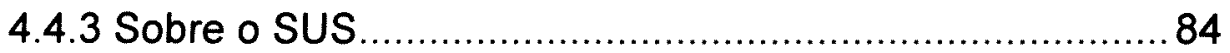

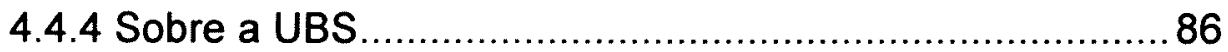

4.5 Identificação dos Aux. de Enf. de Taboão da Serra ............88 


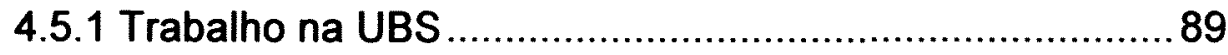

4.5.2 Sobre os Recursos Humanos .................................. 92

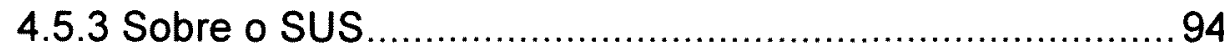

4.5.4 Sobre a UBS ............................................... 97

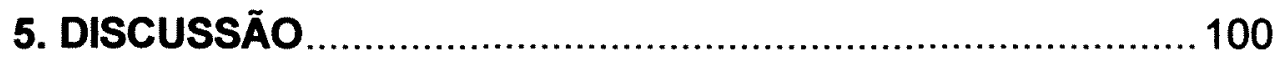

6. CONSIDERAÇÕES FINAIS ....................................... 113

7. REFERÊNCIA BIBLIOGRÁFICA ............................... 117

8. BIBLIOGRAFIA CONSULTADA ............................... 125

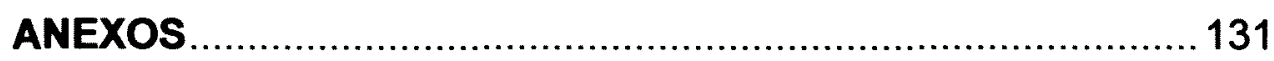

Anexo 1 Identificação das UBS

Anexo 2 Questionário dos Enfermeiros

Anexo 3 Questionário dos Auxiliares de Enfermagem

Anexo 4 Portaria $n^{\circ} 2.553$, de 4 de maio de 1998

Anexo 5 Portaria $n^{\circ} 4$, de 5 de janeiro de 1999

Anexo 6 Portaria n 1.886, de 18 de dezembro de 1997 


\section{INTRODUÇÃO}

A compreensão das transformações sócio-econômicas e políticas ocorridas no âmbito global é indispensável para se poder analisar o impacto das mudanças que ocorrem na política de saúde do país, que, por conseguinte, influenciam nas políticas sociais próprias, principalmente na área da saúde, especificamente junto aos recursos humanos de enfermagem.

A enfermagem, frente a estas transformações, integra-se às práticas do conjunto de trabalhadores da saúde, como parte de um processo coletivo que produz ações nos serviços de saúde.

O presente trabalho pretende estudar a composição da equipe de enfermagem das Unidades Básicas de Saúde dos municípios de Ferraz de Vasconcelos e Taboão da Serra, com ênfase nas atribuições e aspecto quantitativo da equipe de enfermagem, para identificar a participaçăo do pessoal de enfermagem, que deve se processar de diferentes modos, conforme o desenvolvimento político dos municípios, devido aos requisitos exigidos pelo Sistema Único de Saúde, o que deve diferenciar a atuação de seus recursos humanos. 


\subsection{Referencial Teórico}

Apresenta-se neste capítulo o processo de implantação do Sistema Único de Saúde, as suas diretrizes e o seu desenvolvimento, a inserção dos agentes de saúde neste novo sistema e a contextualização da realização do trabalho da enfermagem.

\subsubsection{O Processo de Implantação da Municipalização}

A proposta de municipalização da saúde foi aventada no Brasil já nos anos 60 , no contexto da discussão em torno das chamadas "reformas de base", sendo, inclusive, objeto de debate na $3^{\text {a }}$ Conferência Nacional de Saúde de 1963 (BRASIL 1963).

Esta proposição é um processo político de saúde que procura operacionalizar os princípios do Sistema Único de Saúde (SUS), expressos na Constituição Federal em 1988 e presentes também nos objetivos das Ações Integradas de Saúde (AIS) de 1983, que visava reorientar as políticas de saúde para a reorganização dos serviços, através da integração, acesso universal, hierarquização e regionalização com comando único em cada esfera governamental (BRASIL, 1986; 1988).

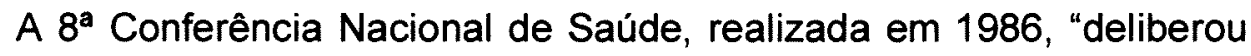
que a reestruturação do Sistema Nacional de Saúde devia resultar na 
A $8^{a}$ Conferência Nacional de Saúde, realizada em 1986, "deliberou que a reestruturação do Sistema Nacional de Saúde devia resultar na criação de um Sistema Único de Saúde, que efetivamente representasse a construção de um arcabouço institucional separando totalmente a saúde da previdência, através de uma ampla Reforma Sanitária”. (HEIMANN, 1992)

Neste sentido, o Estado deve garantir condições dignas de vida e de acesso universal e igualitário às ações e serviços de promoção, proteção e recuperação da saúde, em todos os niveis. E ainda, assumir uma política de saúde integrada às demais políticas econômicas e sociais, assegurando os mecanismos que possam efetivá-las.

A partir da nova Constituição da República de 1988, foram criadas várias tentativas de viabilização de uma assistência plena à população ao direito à saúde. Destacam-se, neste sentido, no âmbito jurídico-institucional, as chamadas Leis Orgânicas da Saúde - Lei nº 8.080/90 e 8.142/90 e as Normas Operacionais Básicas- NOB, editadas em 1991, 1993 e 1996 (BRASIL, 1988; 1991; 1993; 1996).

Com a Lei $8.080 / 90$ foi regulamentado o Sistema Único de Saúde SUS, que agrega todos os serviços governamentais - da esfera federal, estadual e municipal - e os serviços privados (desde que contratados ou conveniados), estes somente de maneira suplementar, responsáveis pela concretização dos princípios constitucionais. 
A NOB-SUS 01/96 tem a finalidade de consolidar o pleno exercício, por parte do poder público municipal, do Distrito Federal e dos Estados, da função da atenção à saúde da população - Artigo 30, inciso V e VII, e Artigo 32, Parágrafo $1^{\circ}$. (BRASIL, 1988).

A municipalização do setor público de saúde tornou-se então, um processo regulamentado por Lei no início da década de 90 no país, notadamente no Estado de São Paulo em que parte dos municípios se responsabilizou pela prestação de serviços básicos de saúde à população, com exceção da Cidade de São Paulo.

As condições de gestão, estabelecidas na NOB-SUS 01/96, explicitam as responsabilidades do gestor municipal, os requisitos relativos às modalidades de gestão e as prerrogativas que favorecem o seu desempenho.

A habilitação dos municípios às diferentes condições de gestão significa a declaração dos compromissos assumidos por parte do gestor perante os outros gestores e perante a população sob sua responsabilidade.

A partir da NOB, os municípios podem habilitar-se em duas condições: 


\section{a) GESTÃO PLENA DA ATENÇÃO BÁSICA \\ b) GESTÃO PLENA DO SISTEMA MUNICIPAL}

Os municípios que não aderirem ao processo de habilitação permanecem, para efeito da NOB, na condição de prestadores de serviços ao Sistema, cabendo à Unidade Federada a gestão do SUS naquele território municipal, enquanto for mantida a situação de não-habilitado, o que hoje quase não se encontra.

A totalidade das ações e de serviços de saúde, no âmbito do SUS, deve ser desenvolvida em um conjunto de estabelecimentos, organizados em rede regionalizada e hierarquizada, e disciplinados segundo subsistemas, um para cada município - o SUS-Municipal - voltado ao atendimento integral de sua própria população, em suas abrangências estadual e nacional (BRASIL, 1996).

O novo papel do municipio, ficou evidente pelo aumento da construção dos estabelecimentos de saúde do setor público, principalmente as Unidades Básicas de Saúde (UBS), tanto no que se refere às instalações, quanto à absorção de recursos humanos, o que refletiu no aumento de produção e da oferta de serviços de saúde. Portanto, o maior desafio em relação ao setor saúde sob a responsabilidade do município é o de apresentar uma estrutura compativel com a sua nova função, para a qual nem sempre está preparado. 
DALLARI (1985) discute a municipalização da saúde, destacando a existência de uma certa unidade cultural, solidariedade social e as possibilidades políticas maiores, e ainda contribui para a realização do direito à saúde por permitir maior participação do município no planejamento e na execução das atividades sanitárias.

Um fator de grande relevância na implantação do SUS, processo irreversivel no país, é o aspecto relacionado à formação de recursos humanos. Com efeito, o Art. $6^{\circ}$. da Lei Orgânica da Saúde $n^{\circ} 8.080$ dispõe, sobre a execução de ações de vigilância sanitária, epidemiológica, saúde do trabalhador e de assistência integral, inclusive farmacêutica. O município ainda participa na formulação da politica e na execução de ações de saneamento básico, na ordenação da formação de recursos humanos na área de saúde, no controle e na fiscalização de serviços, produtos e substâncias de interesse para a saúde, no incremento, em sua área de atuação, do desenvolvimento científico e tecnológico, entre outros.

Destaca-se, na referida Lei, a importância da formação de recursos humanos na área da saúde, deixando a cargo do município este processo, necessitando de pessoal preparado para exercer tal função, além de ser uma ação contínua e relevante para suprir as necessidades de assistência à saúde da população. 


\subsubsection{Recursos Humanos na Municipalização}

O conceito de recursos humanos, segundo MACEDO (1986), "se refere às pessoas que, na sociedade, adquiriram uma capacitação especifica e que assumem responsabilidades na realização de atividades do setor saúde, estejam ou não vinculadas às instituições do setor, isto é, os recursos humanos são considerados como fator produtivo e como atores sociais".

Nos anos 60 , percebia-se os recursos humanos sob uma visão administrativa, como insumo, relacionando quadros quantitativos de pessoal a dados demográficos e indicadores de saúde (QUADRA e AMÂNCIO, 1978).

Sob este ponto de vista, os recursos humanos estão situados apenas como uma ação utilitária e resolutiva, dentro do sistema administrativo, não privilegiando as oportunidades de qualificação profissional e de atualização no processo de trabalho cotidiano.

Porém, há outro enfoque dado à questão dos recursos, baseado na economia política e que vem sendo aplicado na área da saúde, que é a utilização dos recursos humanos como força de trabalho. Neste aspecto, considera-se a produção, o emprego, a renda, a divisão do trabalho, 
incorporando ainda as restrições e possibilidades da base econômica de uma sociedade (MEDICI, 1989; NOGUEIRA, 1983; GIRARDI, 1986; PAIM, 1994).

Verderesi, citada por OLIVEIRA (1996) considera "recursos humanos, mais do que mão de obra e insumo do sistema de produção, são sujeitos do processo produtivo e, portanto, agentes potenciais de mudança"; pode-se considerar que a autora anteriormente mencionada, sugere que há necessidade de se ampliar a concepção, qualificada como utilitária, destes recursos.

BOGUS (1994) refere em seus estudos que a situação dos recursos humanos no processo de municipalização dá conta, além da ausência de diretrizes na área de treinamento e desenvolvimento que prejudicam o que se atribui à mudança de postura profissional, também da ausência de legislação e regulamentação que dêem sustentação à implantação do SUS.

De um modo geral, os recursos humanos têm sido vistos e tratados como um recurso instrumental a mais de um sistema produtor da assistência à saúde. É necessário que fique claro que a composição e a dinâmica dos trabalhadores dos vários niveis de escolaridade e formação, certamente 
deverão sofrer reorientação em função dos novos objetivos e atribuições do SUS, que dispõe em seu art. $5^{\circ}(1990)$, a saber:

a) "identificar os fatores condicionantes e determinantes da saúde e, em conseqüência, formular a política de saúde destinada a promover, nos campos econômico e social, a redução dos riscos de doenças e outros agravos ao bem-estar, mental e social do indivíduo e da coletividade";

b) "prestar assistência às pessoas por meio de ações de proteção e recuperação da saúde, integrando as medidas assistenciais com as preventivas" (BRASIL, 1990).

Essas transformações, como decorrência da intenção entre as várias categorias de profissionais e o próprio objeto de trabalho, apontarão para diferentes técnicas, as quais, estarão sendo sempre influenciadas pelos novos conhecimentos e processos educacionais.

Porém, segundo BOGUS (1994), no caso dos recursos humanos, existem grandes dificuldades para a implementação, nos serviços de saúde, das ações formuladas para a formação e capacitação de pessoal. 0 caminho de difusão das políticas do nivel central e da academia para o nivel de execução é tortuoso e, por isso, as idéias básicas se perdem ou se modificam, impedindo a concretização das mudanças. 


\subsubsection{A Composição da Força de Trabalho da Enfermagem}

No Brasil, a institucionalização da enfermagem ocorreu na década de 20, e a sua profissionalização ocorre com o início da divisão do trabalho (VAZ, 1989). A profissão está classificada em grupos de diferentes qualificações, do nivel elementar ao universitário.

As três categorias que hoje integram a equipe de enfermagem, constituem-se de nível superior, o enfermeiro, que abrange profissional com graduação em curso universitário.

A segunda categoria, compõe-se de elementos de nível médio técnico e auxiliar de enfermagem, e incorpora trabalhadores, correspondentes do primeiro e segundo graus (ginásio e colegial). $\mathrm{O}$ agente de instrução equivalente à conclusão do ciclo colegial denomina-se técnico de enfermagem e aquele que corresponde ao primeiro grau é denominado auxiliar de enfermagem.

E o terceiro, é o de nível elementar ou primário, o atendente de enfermagem em fase de extinção e o agente comunitário de saúde, em fase de implantação em várias regiões do país, notadamente no Nordeste. Este grupo é formado por indivíduos com escolaridade primária que recebem algumas informações básicas e treinamento elementar de enfermagem. 
O enfermeiro, em sua formação, obedece a um currículo mínimo de 2500 horas, onde desenvolve habilidades para a prática de prestação da assistência, as funções administrativas, tais como o planejamento da assistência, organização institucional, direção do pessoal de enfermagem, coordenação dos serviços prestados, supervisão, controle e avaliação das ações de enfermagem.

Segundo a Lei $n^{0} 7.498$, de 25 de junho de 1986, que dispõe sobre a regulamentação do exercício da enfermagem, o auxiliar de enfermagem deve desenvolver atividades sob supervisão, com ações de natureza repetitiva, se envolvendo também em processos simples de tratamento, cabendo-Ihe especialmente: observar, reconhecer e descrever sinais e sintomas, prestar cuidados de higiene e conforto ao paciente e participar da equipe de saúde (BRASIL, 1986).

A Lei do Exercício de Enfermagem (BRASIL, 1986) dispõe ainda quem pode exercer enfermagem no território nacional: o enfermeiro, 0 técnico, o auxiliar de enfermagem e a parteira, estipulando o prazo de dez anos, que findou em 1996, para que se regularizasse a situação daqueles ocupacionais que não tivessem a formação exigida pela Lei, desta forma, ocorreria a extinção da categoria atendente de enfermagem. Apesar da Lei, ainda há um grande contingente de atendentes de enfermagem que não se profissionalizou, por diversos fatores como por exemplo a falta de escolarização. 
A atual proposta de utilização dos agentes comunitários de saúde, que foram implantados em algumas comunidades, se deu através de um Programa do Ministério da Saúde em 1993, e vem causando diversas polêmicas, principalmente entre os profissionais enfermeiros. O Programa de Saúde da Família - PSF, prevê que estes agentes estarão incorporados nos serviços de saúde pública municipal sob supervisão do enfermeiro. Em janeiro de 1997, artigo publicado pelo jornal A Folha de São Paulo, informa que "os agentes comunitários de saúde são responsáveis pelos dois maiores feitos do governo ... na área da saúde: a redução da mortalidade infantil no nordeste e a queda do número de crianças subnutridas de até 5 anos. Nos municipios nordestinos atendidos pelos agentes, a mortalidade infantil caiu pelo menos $20 \%$ de 1994 para cá" (FOLHA DE SÃO PAULO, 1997).

Não se pode negar o trabalho efetivo que os agentes comunitários de saúde vêm desenvolvendo na região Nordeste, porém ainda há controvérsias quanto à sua utilização em grandes centros urbanos, apesar desse ocupacional estar contemplado, em Lei federal pelo Ministério da Saúde, através da Portaria n 1.886, de 18 de dezembro de 1997.

O trabalho produzido por CASTELLANOS, SHIMA, BERTOLOZZI, EGRY (1989) marca um momento histórico da profissão, não só porque trouxe à tona, na área da enfermagem, a discussão sobre os determinantes sociais, políticos e ideológicos pelos quais perpassa a situação atual da 
enfermagem, como buscam apontar para os novos caminhos possíveis para o enfrentamento dos desafios para o futuro da categoria.

Através da análise dos elementos que compõem o processo de trabalho da enfermagem, "A situaçäo da enfermagem nos anos 80 ", as autoras anteriormente citadas identificam diferentes objetos e instrumentos de trabalho. Quanto aos objetos, foi possivel encontrar: o cuidado de enfermagem, a organização da assistência e a consciência dos indivíduos sobre saúde.

Ainda continuando o debate acerca dos desafios, o grupo apresentou algumas considerações sobre o processo de trabalho da enfermagem, tendo como referência os modelos de saúde individual e coletiva:

- processo de trabalho em enfermagem "no modelo de saúde individual", caracteriza-se por dois diferentes processos de trabalho: o processo de trabalho "cuidar" e o processo de trabalho "administrar";

-os processos de trabalho de enfermagem no "modelo de saúde individual" institucionalizado se caracterizam como instrumentos ou meios do processo de trabalho médico;

- o modelo de trabalho em saúde coletiva não tem firmado tão concretamente os seus "momentos", o que tem possibilitado o reconhecimento de diferentes profissionais. Neste modelo são admitidos vários tipos de processos, tais como a educação em saúde, vigilância epidemiológica, assistência à familia, dentre outros; 
-a busca da articulação entre os "momentos" individual e coletivo do processo de trabalho do enfermeiro passa pela operacionalização entre o natural e o social, o indivíduo e o coletivo, o sujeito e a estrutura;

- o processo de trabalho em saúde coletiva está em reconstrução e necessita, para sua organização tecnológica, recriar modelos de processo de trabalho que contemplem objetos e finalidades coletivas (CASTELLANOS, SHIMA, BERTOLOZZI, EGRY, 1989; VERDI, 1993).

Deste modo observa-se que, sem uma referência conceitual de enfermagem, que fundamente seu exercício profissional, não é possível determinar sua área de responsabilidade. Cada enfermeiro identificará de diferentes formas e, em conseqüência, desenvolverá as atividades que considere necessárias. Daí a importância em recuperar a historicidade do cuidado, e respeitá-lo como objeto do saber das ações do profissional de enfermagem (Agudelo in MACHADO, 1995).

A falta de uma identificação e apropriação de seu objeto de trabalho e de seu objetivo social, assim como a divisão do trabalho entre diferentes níveis da enfermagem, gera contradições entre resgatar o cuidado direto ou fomentar as ações gerenciais, acarretando conflitos em relação à formação profissional e à definição do seu papel, tanto dentro da equipe de enfermagem quanto na equipe multiprofissional. 


\subsubsection{O Trabalho do Enfermeiro}

VAZ (1989), ao analisar o trabalho do enfermeiro na rede básica de serviços de saúde, mostrou que "as ações de assistência direta à clientela são as preferidas entre os profissionais, idealizadas dentro das atuais determinações do processo de trabalho; e as ações pedagógicas, embora concebidas como indiscutiveis à reciclagem e à manutenção da força de trabalho nas unidades praticamente não são realizadas". Complementa, colocando ainda que prevalente, a atividade administrativa não conta com a aceitação dos profissionais enfermeiros, pois tal prática sobrevêm ao enfermeiro como exigência intrínseca da própria organização do trabalho de enfermagem.

Ao trabalhador de saúde, tanto se requer um grande domínio de seus procedimentos e do impacto deles sobre o processo saúde-doença e o meio ambiente, quanto se requer o conhecimento de sua incorporação a um conjunto maior, sob pena de tornar sua ação ineficaz quanto ao resultado objetivo de sua intervenção, ou ineficiente, no que se refere ao resultado da combinação de sua intervenção em relação aos demais componentes da saúde. 
Um outro estudo desenvolvido por AGUDELO, 1995, concluiu que os profissionais de enfermagem, cuja formação tem um alto custo social, assim como um alto nível de conhecimento, atitudes e aptidões, estão subutilizados pelas instituições de saúde e marginalizados totalmente em seu exercício profissional, com graves conseqüências, tanto na qualidade da atenção em saúde, quanto na satisfação profissional. Os resultados para esta situação se voltam na insuficiência deste pessoal, demonstrada por estudos em diversas instituições e paises (AGUDELO, 1995). Influem também, a flexibilidade institucional para designar e "inventar" funções de acordo com as necessidades de cada momento e o contraste que existe entre a ampla gama de especialidades médicas e as restritas oportunidades de especialização que tem os enfermeiros vinculados aos serviços de saúde.

A ausência de consenso profissional acerca de suas funções e atividades, e a indefinição de um modelo assistencial, dificulta o estabelecimento de uma política assistencial de enfermagem em qualquer instituição de saúde. Além disso, o extenso campo de ação em que devem desenvolver estes profissionais, afeta não só a coerência interna de suas condutas, como também divide os grupos, o que os limita de atuar organizadamente para reconstruir e reorientar seu perfil profissional. 
$\mathrm{Na}$ enfermagem de saúde pública existem condições para desenvolver um modelo profissional autônomo e de maior impacto e mais participativo nos campos da promoção da saúde e prevenção de doenças. Mas este é o espaço que concentra menor presença de profissionais e maior dispersão. É também onde se requer uma maior fundamentação no conhecimento das relações saúde-sociedade, onde as pressões políticas se impõem sobre a racionalidade técnica na hora de tomar decisões.

Tomando como referência as diferentes expectativas que se têm em relação a este profissional, de um lado, na organização da produção de serviços de saúde predomina um modelo assistencial com propostas à gerência das ações de saúde, dos recursos humanos e materiais, enfim, da organização da infra-estrutura necessária à realização da assistência em saúde. Por outro lado, a expectativa de trabalho do próprio enfermeiro está mais voltada aos aspectos técnicos da assistência visando a integrar ações preventivas e curativas. Tal abordagem é predominante durante a formação profissional. (VILLA, 1992)

Quando nos reportamos à história do processo de divisão do trabalho na enfermagem, verificamos uma realidade diferente das aspirações que se idealizam, tanto em suas funções sociais de cuidar, quanto de administrar o cuidado, ou gerenciar - como se denomina atualmente. Nos últimos anos, o processo de trabalho do enfermeiro sofreu transformações, tanto no objetivo 
quanto na finalidade deste processo, assim como na formação, denominação e atividades desempenhadas pelos agentes e, sobretudo, no corpo de conhecimento.

Os enfermeiros, nos atuais serviços de saúde, têm se distanciado das atividades correspondentes à sua preparação técnica e têm assumido atividades diversas, tais como: administração de pessoal, administração de recursos materiais, alimentação do sistema de informação; são as tarefas que muitas vezes outras pessoas não realizam. Esta situação tem sido constatada por diferentes estudos. Um realizado por antropólogos, em Buenos Aires - Argentina -, refere:

"A ampla gama de funções que deve cumprir: distribuição de trabalho ao pessoal: disposição do pessoal nos distintos dias, turnos e serviços: distribuição de roupas, materiais, medicamentos e aparatos: coordenação dos serviços de diagnóstico e tratamento: atenção aos familiares dos pacientes: atenção aos pacientes, etc., dilui o perfil de seu rol e as dispersa em um sem número de tarefas que se desviam do objetivo da enfermagem". (AGUDELO, 1995)

Esta situação ambigua de trabalho em enfermagem se expressa nas dificuldades que o profissional tem encontrado, tanto no que tange ao 
desempenho de uma multiplicidade de funções quanto na compreensão de sua função no processo de trabalho em saúde.

As grandes controvérsias que surgem no trabalho do enfermeiro estão justamente na dificuldade de compreender a natureza de suas atividades, que tem sido abordada de forma polarizada em duas vertentes: a assistencial e a gerencial ou administração em enfermagem, como já foi mencionado anteriormente.

Desde a institucionalização da enfermagem brasileira sempre houve uma preocupação em conhecer, estabelecer e normatizar o que fazem seus agentes nos serviços de saúde, devido à diversificação da categoria profissional e à divisão técnica do trabalho que vêm se intensificando com o avanço tecnológico.

A literatura sobre a enfermagem tem produzido inúmeros estudos sobre estas funções do enfermeiro, que analisam cada atividade separadamente e independente das demais atividades desenvolvidas por outros setores na produção de serviços de saúde (ADAMI, 1976; FRANCO, 1987; TREVIZAN, 1986; VILLA, 1992).

Estas atividades encontram-se agrupadas em Assistência de Enfermagem e Administração em Enfermagem. Na primeira, a concepção de assistência centra-se, prioritariamente, no conceito de cuidar, definido como 
uma relação entre enfermeiro e cliente centrada na satisfação das necessidades humanas básicas (HORTA, 1970), tomadas como universais e abstratas, comuns a todos os homens, deslocadas dos objetivos institucionais e da dinâmica social da organização tecnológica do trabalho.

O outro grupo de atividades, apresentado na literatura, aborda a Administração em Enfermagem. A maior parte dos textos que descrevem esta atividade (OLIVEIRA, 1992; TREVIZAN, 1986) fundamenta-se nas noções da Teoria Geral da Administração (CHIAVENATO, 1983). Esta abordagem transforma o homem em mais um insumo material, entre outros, os recursos humanos. A perspectiva da Teoria da Administração atribui a capacidade de ordenar qualquer etapa do processo de prestação de serviços de enfermagem, constituindo-se numa normatização prescritiva e idealizada das possibilidades de se administrar um serviço, esteja este inserido em uma empresa pública ou privada.

Limita-se pois, a descrever a estrutura hierárquica da organização, as funções e as etapas do processo administrativo (planejar, organizar, dirigir e controlar). Este enfoque não se propõe a captar o real da prática de enfermagem no seu próprio movimento nas instituições onde se organizam as práticas de saúde. 
A utilização das noções da Teoria Geral da Administração, como principal instrumento de reordenação da assistência de enfermagem, não considera o peso decisivo que nesse assunto tem "o modo como são produzidos os serviços de saúde, os determinantes político-institucionais, bem como as forças sociais detentoras de diferentes projetos e defensoras de diversas políticas conforme seus interesses de manutenção ou de transformação dessa estrutura" (CAMPOS, 1990). Nesse enfoque, deixa-se de apreender a dinâmica social das relações da prática de enfermagem com as outras práticas de saúde em momentos históricos e situações concretas.

São poucos e recentes os estudos como os realizados por MENDES e GONÇALVES (1994); ROCHA e ALMEIDA (1991) que tecem considerações a respeito do trabalho do enfermeiro de saúde pública, permitindo a compreensão deste campo de atividades, para além dos seus aspectos organizacionais, burocráticos ou técnico-científicos em geral. Estes autores discutem aspectos do trabalho da enfermagem, a partir do referencial do materialismo-histórico e dialético, abordando as ações e funções deste profissional, articuladas à organização do trabalho na saúde em diferentes períodos históricos. Consideram a enfermagem enquanto parte de um processo coletivo de trabalho, articulada às demais práticas de saúde. 


\subsubsection{Os Recursos Humanos em Enfermagem Frente ao SUS}

A $1^{\text {a }}$ Conferência Estadual de Saúde de São Paulo (1991) destacou, quanto à política de recursos humanos, três aspectos que sistematizam o modo como se pode ponderar e, conseqüentemente, como deveriam ser abordados:

1. como principal riqueza e patrimônio do Sistema Único de Saúde: partindo do princípio de que os resultados do setor saúde, quantitativos ou qualitativos, dependem da relação entre cliente/comunidade e a equipe de saúde. Assim, é preciso pensar os gastos com o setor como investimentos de grande importância;

2. como meio para a produção dos serviços de saúde: o investimento em recursos humanos é fundamental para alcançar bons resultados, como a melhoria dos niveis de saúde da comunidade atendida;

3. como agentes de mudança: ao serem sensibilizados pelos objetivos do Sistema Único de Saúde, os trabalhadores da área da saúde podem se constituir em importantes multiplicadores de idéias e como agentes de mudanças nos serviços de saúde.

Partindo principalmente do terceiro aspecto apontado, poder-se-ia esperar que os próprios trabalhadores se constituíssem, como sujeitos do processo de reorganização do sistema de saúde. Neste sentido, se incluiria a democratização das informações e das decisões nos serviços, a integração das equipes e a integralidade da assistência. 
O Grupo de Trabalho designado pelo Ministro da Saúde em 1989 (BRASIL, 1989), para o estudo da situação dos recursos humanos frente ao SUS destacou as seguintes tendências:

a) "bipolarização da força de trabalho do setor, historicamente representada pela concentração nas categorias de médico e atendente de enfermagem, ou seja, aproximadamente dois terços do contingente de trabalhadores empregados na área".

TANAKA (1991) ao estudar "A municipalização dos serviços de saúde no Estado de São Paulo", assinala que o número de médicos em 1985, era 18,5 mil e em 1987, passou para 23,4 mil, correspondendo a um aumento de $26,50 \%$. No grupo dos atendentes de enfermagem, os mesmos passaram de 6,7 mil em 1980, para 9,8 mil em 1987, apresentando um aumento de $46,3 \%$ em seus valores.

Apesar dos estudos mencionados não abordarem o quantitativo de enfermeiros, chama a atenção o aumento do número destes profissionais; pelo demonstrado por TANAKA (1991), foram os que mais cresceram nos estabelecimentos públicos, passando de 2,8 mil em 1985, para 4,4 mil em 1987, significando um aumento de $57,70 \%$. 
No que se refere ao pessoal de nivel intermediário ou médio - técnico e auxiliar de enfermagem - os mesmos passaram de 2,1 mil em 1980 para 4,3 mil em 1987, apresentando um incremento de $104,70 \%$.

Constata-se portanto que, no Estado de São Paulo, a chamada bipolarização médico-atendente de enfermagem praticamente inexiste. Enquanto na área médica houve um aumento de $26,50 \%$, no que se refere aos enfermeiros, o aumento foi de $57,70 \%$ e, quanto ao auxiliar de enfermagem, a sua quantidade praticamente dobrou - $104,70 \%$, ao contrário dos atendentes, cujo aumento foi apenas de $46,30 \%$.

MEDICI (1989) chama a atenção para a utilização maior de médicos do que de enfermeiros no Brasil, pela própria tradição cultural. Assim, no período de 1977 a 1983, formaram-se no pais 56.852 médicos e foram oferecidos aos mesmos 74.815 empregos; em contrapartida, no que refere aos enfermeiros, formaram-se no mesmo período 23.033 e o número de empregos foi de apenas 7.629.

b) "participação crescente da mão de obra feminina, representando aproximadamente $60 \%$ do total" (BRASIL, 1989).

Deve ser destacado que, pelo fato da enfermagem reunir no conjunto de seus trabalhadores a maior quantidade de mulheres, não faz com que as enfermeiras por si só deixem de procurar o mercado de trabalho, por 
exemplo, algumas por casarem e, em conseqüência, o aparecimento de filhos, se faz necessário permanecer no lar para os afazeres domésticos.

De acordo com a nossa vivência, ressalta-se também, o fator sócioeconômico que é fundamental, hoje, para manter o equilíbrio da familia brasileira, fazendo com que a mulher procure muito mais o emprego fora para auxiliar na manutenção da casa.

O trabalho na enfermagem é notadamente estratificado por níveis de formação, com escassas delimitações das ações desenvolvidas em cada categoria. O predomínio de mulheres em sua composição, em um mundo onde o poder é masculino, tem construído uma cultura de trabalho paralela à da família, onde a autoridade paterna se atribui ao médico e o da mãe submissa e obediente, à enfermeira.

Em artigo de MACHADO (1987) "A participação da mulher na força de trabalho em saúde no Brasil - 1970/1980" constata-se que, desde o primeiro recenseamento brasileiro, realizado no século passado (1872) até o último (1980), mudanças surpreendentes aconteceram na evolução do mercado de trabalho para a mulher.

Assim, em 1872, as mulheres representavam $45,5 \%$ da força de trabalho efetiva no Brasil, basicamente constituida por escravas. Após a 
abolição da escravatura, o quadro se alterou. Em 1940, o contingente feminino somava 19\%; em 1950, 14\%; em 1960, 13\%; em 1970 cresceu para $20 \%$, atingindo em $1980,38,4 \%$ até alcançar $60 \%$ nos dias de hoje.

Portanto, a tendência à feminilização no período 1970/1980 cresceu $50 \%$, ou seja, em 1970 a força de trabalho feminina no setor saúde representava $41 \%$, passando para $63 \%$, concordando com o valor assinalado pelo grupo nomeado pelo Ministério da Saúde, acima citado.

Ainda de maior significado foi o incremento da mão-de-obra de maior qualificação. Em 1970, representava no conjunto da força de trabalho de nivel superior 20\%, passando para $39 \%$ em 1980 e, seguindo a mesma progressão, atingindo valores maiores em 1990. Destacam-se particularmente as categorias médica e odontológica, que acusam crescimento de $302 \%$ e $344 \%$, respectivamente, naquele período.

A força de trabalho em enfermagem é essencialmente feminina, tanto nas categorias de nivel superior quanto na de nível médio e elementar.

Ultimamente, da mesma forma que as profissões preponderantemente masculinas passaram a ser desenvolvidas por mulheres, principalmente na área da saúde, alguns postos de trabalho de enfermagem são ocupados por elementos do sexo masculino. 
A taxa de participação masculina no pessoal de nivel superior, entre as décadas de 70 e 80 , aumentou substancialmente, evoluindo de $4.0 \%$ para $6.0 \%$, alcançando em 1980 a $8.5 \%$ (MACHADO, 1987).

c) "rejuvenescimento significativo da força de trabalho empregada".

Segundo MACHADO (1987), o processo de rejuvenescimento por que passa o conjunto da força de trabalho em saúde, representa uma das tendências desse setor de atividades.

Com efeito, a análise dos dados relativos à faixa etária dos profissionais da saúde, indica um processo acentuado e nítido de rejuvenescimento, destacando-se o contingente médico feminino.

Os profissionais de enfermagem tiveram um alto incremento relativo em sua magnitude ao longo da década de 70 , especialmente os de nível superior, que em 1980 era cerca de duas vezes e meia, superior ao existente em 1970. Este rápido aumento do número de enfermeiros decorre do fato de terem sido eles formados em sua maioria na década de 70 . 0 reflexo desta elevada taxa de formação profissional de enfermeiros foi o rejuvenescimento da estrutura etária destes profissionais. Assim, observase um expressivo aumento da participação dos profissionais de até 29 anos 
(20.9\% para $29.5 \%$ ) entre 1970 e 1980 , e entre os 30 e 59 anos atingiu $77.2 \%$ em 1970, e $68.9 \%$ em 1980 (MACHADO, 1987).

Tal fato não ocorre com os elementos de nivel médio e elementar, pois até 29 anos a porcentagem era de $44.7 \%$ em 1970 , passando para $45.1 \%$ em 1980 , enquanto que no grupo de 30 a 59 anos, a porcentagem em 1970 foi de $53.8 \%$ mantendo-se praticamente inalterada em 1980 (53.5\%) (MACHADO, 1987).

Assim, constata-se que o rejuvenescimento da força de trabalho em enfermagem está intimamente correlacionado com a elevação do perfil de qualificação do profissional, dado que é observado principalmente para os profissionais de nível superior.

d) "aumento do nivel de escolaridade nas diversas categorias, levando a uma qualificação crescente".

Na composição interna das categorias de enfermagem no Brasil, no período 1976/1984, MEDICI (1987) assinala um aumento do número de enfermeiros de 12.251 para 21.766 , representando $78 \%$, enquanto que a categoria de auxiliares de enfermagem cresceu de 44.204 para 100.034 no mesmo período, $126 \%$ de aumento. E o grupo de atendentes de enfermagem passou de 124.079 para $184.723,49 \%$ de aumento, valores 
que assinalam um aumento na formação da categoria de auxiliares de enfermagem e, em contrapartida, um número menor, de pessoal de nivel elementar, até aquela data. Isto demonstra que vem ocorrendo um aumento na qualificação da composição interna da categoria de enfermagem.

O grupo nomeado pelo Ministro da Saúde ainda entende que, como conseqüência dessa tendência, pode-se inferir que está em processo uma discreta diminuição da bipolaridade, abrindo espaço para o crescimento e a absorção de outras categorias de nível superior, bem como ampliando a participação das categorias de nível médio (técnico e auxiliar), principalmente na área da enfermagem.

Ainda na área de recursos humanos, o grupo de trabalho detectou os principais problemas que, certamente, irão se constituir em sérios entraves à transição para o SUS, devido a uma série de fatores tais como o fato de haver uma habilitação formalizada, mas desqualificada para o serviço; políticas e práticas de capacitação em programas, que fortalece a polarização e a fragmentação do trabalho em saúde; utilização de metodologias pedagógicas que não têm como eixo substantivo o processo de trabalho; inexistência de programas de capacitação permanente para o pessoal da rede de serviços; multiplicidade de treinamentos e de cursos sem uma coordenação que garanta a implementação de um projeto global de desenvolvimento de recursos humanos. 
Além destes, existem ainda uma concentração sócio-institucional dos recursos humanos em regiões mais desenvolvidas do país e nas capitais dos estados, excesso de profissionais de saúde nos níveis mais centralizados de governo, maior emprego no segmento hospitalar da rede de serviços.

Outros entraves para o SUS ainda são a inadequação de composição das equipes de saúde frente às demandas sociais e epidemiológicas, inexistência de metodologia que permita a definição de parâmetros qualitativos e quantitativos para lotação de pessoal nas unidades de saúde, tendo em vista a transição para o Sistema Único de Saúde e a inexistência de um sistema de informação de recursos humanos que subsidie a definição de diretrizes e a implementação de política.

Outros problemas detectados pelo grupo de estudos foi a multiplicidade de órgãos e estruturas nas Instituições de Saúde Federais, Estaduais e Municipais que lidam com questões afetas a recursos humanos, sem qualquer articulação, a falta de autonomia e de condições dos órgãos de recursos humanos das instituições de saúde para desenvolvimento de suas competências, tendo em vista a complexidade da área, a gerência da área de recursos humanos operada por quadros não capacitados e despreparados para as atuais funções, a inobservância, em alguns planos de carreiras propostos ou existentes, das denominações aprovadas pelo setor educacional para as categorias profissionais, da mesma forma a 
inexistência de mecanismos legais que possibilitem a ascensão funcional dos servidores habilitados para o exercício de novas funções (exemplo dessa situação é o atendente que freqüentou o curso de auxiliar de enfermagem), e de estudos que contemplem as questões de inserção dos profissionais de saúde nas instituições, inclusive dos recursos realmente destinados para pagamento de pessoal.

Além dos problemas já mencionados, há um outro aspecto relacionado com o modelo assistencial, que é a percepção dos trabalhadores de saúde a respeito da forma como a população usuária percebe a finalidade do serviço. Deste modo, há a necessidade de conhecer o contingente de pessoal de enfermagem, as suas atividades devem estar claras, verificando como eles se enquadram neste processo de mudanças que vem ocorrendo no Sistema de Saúde do País. 


\section{OBJETIVOS}

\subsection{Objetivo Geral}

Analisar a composição da equipe de enfermagem, das Unidades Básicas de Saúde - UBS de dois municipios da Grande São Paulo, com ênfase nas atribuições e aspecto quantitativo.

\subsection{Objetivos Específicos}

2.2.1 - identificar a situação da municipalização da saúde nos municípios selecionados;

2.2.2 - estudar a composição das equipes de enfermagem que desempenham atividades nas UBS dos referidos municipios;

2.2.3 - quantificar a equipe de enfermagem nos referidos municípios;

2.2.4 - identificar as atribuições da equipe de enfermagem;

2.2.5 - conhecer o trabalho realizado pela equipe face as suas atribuições; 


\section{METODOLOGIA}

O presente estudo teve como objetivo geral a análise da composição da equipe de enfermagem das Unidades Básicas de Saúde, com ênfase nas suas atribuições e sob seu aspecto quantitativo, frente a implantação do Sistema Único de Saúde, realizado nos municípios de Ferraz de Vasconcelos e Taboão da Serra.

No critério de escolha dos municipios considerou-se os aspectos de desenvolvimento destes, no processo de implantação do SUS, o seu porte, médio, ou seja, municipios "dormitórios", com pequena arrecadação per capita, com até 200.000 habitantes. Possuem características epidemiológicas e populacionais semelhantes e pertencem à região metropolitana de São Paulo.

A abordagem escolhida baseou-se em identificar, na prática de enfermagem, enquanto trabalho socialmente estruturado e institucionalizado, o sentido de conjunto de suas caracteristicas, evidenciando as atividades desenvolvidas pelos seus agentes. 
Inicialmente foram identificadas as UBS existentes em cada município, que foram conhecidas através de visitas com um roteiro pré-estabelecido, elaborado para a caracterização destas Unidades. Anexo 1

Uma vez estabelecida a população e o local de desenvolvimento da pesquisa, foram feitas a quantificação e a qualificação da equipe de enfermagem através do seu trabalho. Para a obtenção dos dados, foram distribuidos questionários individuais e específicos para cada categoria, pré-testados em população semelhante, aos membros componentes da equipe composta de enfermeiros e auxiliares de enfermagem, que trabalham nas UBS dos dois municípios selecionados. Anexos 2 e 3

Foram distribuidos 29 questionários para auxiliares de enfermagem e 6 para enfermeiros, destes retornaram respondidos um total de 18 questionários dos auxiliares de enfermagem e 4 dos enfermeiros do município de Ferraz de Vasconcelos. No municipio de Taboão da Serra foram entregues 86 questionários para auxiliares de enfermagem e 17 para enfermeiros, foram devolvidos 40 do auxiliares e 8 de enfermeiros. Houve, no entanto, muita perda no retomo dos instrumentos de coleta de dados. 
Nos instrumentos de coleta de dados foram abordadas questões específicas para cada membro do pessoal de enfermagem, onde considerou-se o trabalho do enfermeiro e do auxiliar de enfermagem nas UBS, identificando as atribuições que desempenham, especificamente foram focalizados os aspectos sobre a identificação, o Sistema Único de Saúde - SUS, os recursos humanos e Unidade Básica de Saúde - UBS. Não existem técnicos de enfermagem nem agentes comunitários de saúde nos municipios estudados.

Uma dificuldade sentida foi o fato, dos dados obtidos, muitas vezes apresentaram, visões consensuais e contraditórias de uma mesma realidade, o que fez com que fosse descrito todas as opiniōes obtidas, para um melhor entendimento.

Realizou-se inicialmente, a identificação da situação dos municipios no Sistema Único de Saúde, através de consultas de documentos oficiais.

Conforme o grau de desenvolvimento do município, espera-se que a participação do pessoal de enfermagem deva se processar de modo diferente, pois os requisitos do SUS são diversificados. Desta forma, a atuação da enfermagem e a sua situação de trabalho devem ser diferenciadas. 


\subsection{Caracterização dos Municípios}

\subsubsection{Ferraz de Vasconcelos}

Ferraz de Vasconcelos surgiu como um vilarejo que acompanha o caminho da via férrea. Era um bairro do municipio de Poá, que em 1954 se emancipou como município. Pertence à Região Metropolitana de São Paulo, cuja sede da regional está localizada em Mogi das Cruzes.

Está situado na região leste da Grande São Paulo, distante aproximadamente $36 \mathrm{Km}$ da Capital. A área total é de $25 \mathrm{Km}^{2}$ e está a uma altitude de $755 \mathrm{~m}$.

Faz limite ao Norte e Oeste com o municipio de São Paulo, ao Sul com os municipios de Mauá e Ribeirão Pires e a Leste com os municípios de Poá e Suzano.

Está dividido pela via férrea, que forma uma barreira na ligação entre as duas partes do município. Existem apenas dois pontos de ligação, um, no centro da cidade, através de um viaduto, sendo esta a principal via de ascesso e outra, na entrada da cidade. 
Está equipado com oito unidades básicas de saúde, uma unidade de fisioterapia e um laboratório de patologia clínica acoplado a uma UBS. É sede de um hospital regional, que serve à DIR III, e com características de hospital geral, com capacidade para 135 leitos disponiveis.

A economia da região é centrada na indústria, na prestação de serviços e no trabalho informal. Altamente urbanizado (porcentagem da população urbana em 1996 de 95\%), tem uma densidade demográfica elevada (em 1996 de 4.879,68 hab./ $\mathrm{Km}^{2}$ ) e um indice de alfabetização de adultos de 70\%(taxa de alfabetização do grupo maior de 15 anos em 1996 de 70\%). Fonte: Prefeitura Municipal de Ferraz de Vasconcelos

A água é captada e tratada no municipio de Suzano, e a distribuição é feita pela SABESP. Cerca de $95 \%$ da população é atendida com água tratada. (Prefeitura Municipal de Ferraz de Vasconcelos, 1998)

O sistema de esgotamento sanitário do município atende cerca de $70 \%$ dos esgotos domésticos, sendo que $15 \%$ é tratado e o afluente restante coletado é lançado sem nenhum tratamento nos rios e córregos da região 
Tabela 1 - INDICADORES DEMOGRÁFICOS - 1998

\begin{tabular}{|l|l|}
\hline População Feminina & 66.981 \\
\hline População Masculina & 65.725 \\
\hline Porcentagem da População Urbana & 98,8 \\
\hline Nascidos Vivos & 3.553 \\
\hline Taxa de Natalidade (em \%) & 26,8 \\
\hline
\end{tabular}

Fonte: Fundação SEADE

\section{Tabela 2 - DADOS POPULACIONAIS}

\begin{tabular}{|l|l|}
\hline População Total - 1999 & 137.581 \\
\hline Densidade Demográfica hab/Km² - 1997 & $4.879,7$ \\
\hline
\end{tabular}

Tabela 3 - INDICADORES SÓCIO-ECONÔMICOS - 1996

\begin{tabular}{|l|l|}
\hline Taxa de Analfabetismo população > 15 anos (\%) & 30 \\
\hline Domicilios com Abastecimento Adequado de Água (\%) & 95 \\
\hline Domicílios com Esgotamento Sanitário Adequado (\%) & 70 \\
\hline
\end{tabular}

Fonte: Fundação SEADE

Tabela 4 - INDICADORES DE MORTALIDADE - 1998

\begin{tabular}{|l|l|}
\hline Taxa de Mortalidade Geral (\%) & 5,4 \\
\hline Total de Obitos & 713 \\
\hline
\end{tabular}

Fonte: Fundação SEADE 
Tabela 5 - COEFICIENTES DE MORTALIDADE - 1995

\begin{tabular}{|l|l|}
\hline $\begin{array}{l}\text { Coeficiente de Mortalidade por Doenças do } \\
\text { Aparelho Circulatório (por 100.000 hab.) }\end{array}$ & 227,1 \\
\hline $\begin{array}{l}\text { Coeficiente de Mortalidade por Doenças do } \\
\text { Aparelho Respiratório (por } 100.000 \text { hab.) }\end{array}$ & 121,3 \\
\hline $\begin{array}{l}\text { Coeficiente de Mortalidade por Causas Externas } \\
\text { (por } 100.000 \text { hab.) }\end{array}$ & 106,6 \\
\hline $\begin{array}{l}\text { Coeficiente de Mortalidade por Neoplasias (por } \\
100.000 \text { hab.) }\end{array}$ & 91,8 \\
\hline $\begin{array}{l}\text { Coeficiente de Mortalidade por Doenças do } \\
\text { Aparelho Digestivo (por 100.000 hab.) }\end{array}$ & 41,8 \\
\hline $\begin{array}{l}\text { Coeficiente de Mortalidade por Doenças } \\
\text { Infecciosas e Parasitárias (por } 100.000 \text { hab.) }\end{array}$ & 29,5 \\
\hline
\end{tabular}

Tabela 6 - INDICADORES DE MORBIDADE - 1996/1997

\begin{tabular}{l|c|c}
\hline Casos Notificados de Dengue & 0 & 1 \\
\hline Tuberculose - incidência por 100.000 hab. & 59 & 63,1 \\
\hline Hanseniase - prevalência por 10.000 hab. & 0,2 & 0,3 \\
\hline Casos Notificados de Sarampo & 0 & 142 \\
\hline Casos Notificados de AIDS & 76 & 68 \\
\hline
\end{tabular}

Fonte: Fundação SEADE 
Tabela 7 - INDICADORES DE RECURSOS, ACESSO E COBERTURA $1996 / 1997$

\begin{tabular}{|l|c|}
\hline Médicos por 10 mil habitantes & 2,1 \\
\hline Enfermeiros por 10 mil habitantes & 0,5 \\
\hline Leitos por mil habitantes & 1,1 \\
\hline Cobertura Vacinal DPT < 1 ano & 105,6 \\
\hline Cobertura Vacinal Antipoliomielite < 1 ano & 123,7 \\
\hline Cobertura Vacinal BCG < 1 ano & 142,1 \\
\hline Média Mensal de Procedimentos Ambulatoriais SUS & 32.000 \\
\hline
\end{tabular}

Fonte: Secretaria Municipal de Ferraz de Vasconcelos

Tabela 8 - DOENÇAS DE NOTIFICAÇÃO COMPULSÓRIA - 1996/1997

\begin{tabular}{|l|l|l|}
\hline Sarampo & 0 & 142 \\
\hline Tuberculose Pulmonar & 70 & 77 \\
\hline AIDS & 76 & 68 \\
\hline Meningites & 38 & 31 \\
\hline Doença Meningocócica & 28 & 10 \\
\hline Rubéola & 0 & 06 \\
\hline Esquistossomose & 07 & 05 \\
\hline Hanseniase & 02 & 03 \\
\hline Leptospirose & 06 & 01 \\
\hline Dengue & 0 & 01 \\
\hline Sindrome da Rubéola Congênita & 0 & 01 \\
\hline Tuberculose Extra Pulmonar & 02 & 0 \\
\hline
\end{tabular}

Fonte: Secretaria Municipal de Saúde de Ferraz de Vasconcelos 
Segundo os indicadores, o perfil de saúde do município não está distante da média nacional. Paradoxalmente, suas peculiaridades representam aquelas generalidades: doenças com duração prolongada, que não integram os programas de vacinação e nutrição. O município apresenta uma cobertura vacinal adequada. Chama atenção a diminuição da Taxa de Mortalidade Geral, como ilustra o Gráfico 1, a Taxa de Mortalidade infantil (19,4 - 1998) vem decrescendo, mas ainda apresenta uma média considerada alta (32,8 nos últimos quatro anos).

\section{Grático 1 - TAXAS DE MORTAUDADE GERAL}

FERRAZDE VASCONCEIOS- S.P. - 1992-1998

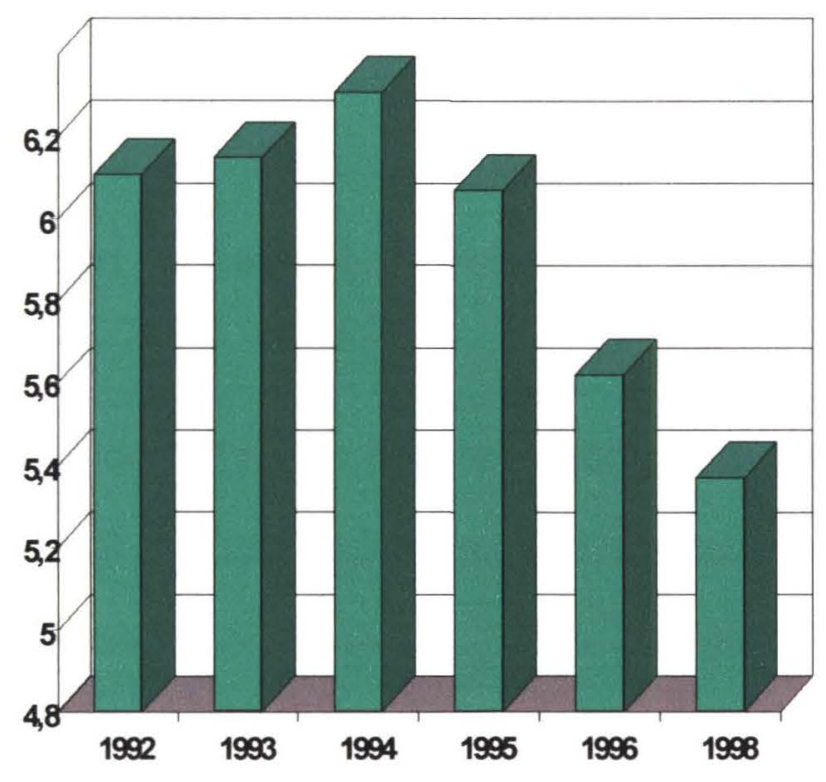


As causas de óbito por doenças cardiacas, ocupam, em 1995, o primeiro lugar, seguidas pelas afecções respiratórias e neoplasmas malignos. Dos casos de notificação compulsória, merece destaque o número de casos de sarampo em 1997, a AIDS com incidência de 5,57/10.000 hab. até outubro/97 e a Tuberculose com 72 casos em 1996 e 77 até outubro de 1997 (Incidência de 6,31/10.000 hab.).

Também deve-se mencionar as mortes causadas por fatores externos (homicídios, acidentes com veículos automotores, etc.) que estão caracterizando fatores ligados à violência urbana uma vez que a taxa de urbanização do município é elevada.

\subsubsection{Município de Taboão da Serra}

A história de Taboão da Serra acompanha o período de 1915 a 1940 em que a circulação rodoviária, em geral, provocou o surgimento e reativação de diversos pequenos povoados ao longo dos caminhos e estradas existentes. Esses pontos são os chamados "povoados entroncamentos", uma vez que viviam em função do tráfego que por elas passava, e estão localizados nos principais entroncamentos das estradas,. 
Pesquisas efetuadas abrangendo os últimos 100 anos de Taboão da Serra, confirmam que a cidade era um bairro do Distrito da Capital. Em 1953 Taboão da Serra continuava sendo um bairro, mas naquele momento pertencente ao Distrito de Embú. Nesse mesmo ano, em dezembro, desmembrou-se de Embú e foi elevado a Distrito do Município de Itapecerica da Serra. Em 1958 a comarca foi novamente desmembrada, sendo criados os municípios de Embú e Taboão da Serra. (Prefeitura de Taboão da Serra, 1998)

O municipio de Taboão da Serra pertence à Região Metropolitana de São Paulo, e a sede da regional está em Itapecerica da Serra. Localiza-se na região sudeste da Grande São Paulo, a altitude chega a aproximadamente $740 \mathrm{~m}$, distanciando-se $15 \mathrm{Km}$ da capital (no seu menor percurso).

Apresenta área de $\mathbf{2 0}$ quilômetros quadrados, totalmente fora de área de proteção a mananciais, em terreno bastante acidentado e cortado por inúmeros córregos e riachos que deságuam na Bacia do Pirajuçara (Rio Pirajuçara, Poá e das Olarias).

É delimitado a sudeste pelo município de Embú (aproximadamente 30\%) e no seu perímetro restante pela capital (distrito de Raposo Tavares, Vila Sônia, Vila Andrade e Campo Limpo) que, praticamente, o envolve. 
O município é cortado pela Rodovia Régis Bittencourt (BR-116), sua principal via de acesso e escoadouro da produção industrial local. Esta importante rodovia, divide o município em duas partes. Existem dois pontos de ligação entre os bairros e o centro da cidade.

Em terreno acidentado (serra), Taboão da Serra tem seu espaço útil disputado pelo setor imobiliário, apresentando um dos maiores indices de construção do país.

Através de dados do Censo Demográfico Brasileiro de 1991 (IBGE), o municipio apresentava uma Taxa Média de Crescimento Anual (TMCA) de $4,59 \%$, muito aquém do crescimento esperado a partir do Censo Demográfico de 1980. As Tabelas 1 e 2 apresentam o histórico da população residente de 1960/1994 e a variação da Taxa Geral de Crescimento Anual (TGCA) no período.

Tabela 9 - Distribuição da população residente nos anos de 1960, 1970, 1980, 1991 e 1994, Taboão da Serra, 1994.

\begin{tabular}{c|c}
\hline ANO & $\begin{array}{l}\text { POPULAÇÁO EM N } \\
\text { ABSOLUTO }\end{array}$ \\
\hline 1960 & 7.173 \\
\hline 1970 & 40.945 \\
\hline 1980 & 97.642 \\
\hline 1991 & 158.738 \\
\hline 1994 & 182.945 \\
\hline
\end{tabular}

Fonte: Fundação SEADE 
TABELA 10 - Variação da Taxa Geral de Crescimento Anual - TGCA no período de 1960 a 1991, segundo ano de Censo, Taboão da Serra, 1993.

\begin{tabular}{c|c}
\hline PERIOOO & TGCA(\%) \\
\hline 1960 a 1970 & 19,03 \\
\hline 1970 a 1980 & 9,08 \\
\hline 1980 a 1991 & 4,59 \\
\hline
\end{tabular}

Fonte:IBGE

Segundo dados da Fundação SEADE, a população total de Taboão da Serra no ano de 1998 era de 192.242 habitantes, sendo 98.860 mulheres $(51,43 \%)$, e 93.382 homens $(48,57 \%)$. Em 1999 a população total é de 195.926 habitantes. Em virtude da pequena extensão territorial do municipio, a densidade demográfica atinge $8.743,8$ habitantes por $\mathrm{Km}^{2}$.

A economia da região é predominantemente centrada na prestação de serviços e indústrias. Excluindo-se o serviço pủblico, ambos os setores, em 1990, respondiam por $94,62 \%$ das vagas de empregos ofertados, ficando o comércio com apenas $5,38 \%$ das mesmas.

Apesar de ser considerado, historicamente, como municipio "dormitório" da Grande São Paulo, Taboão da Serra apresenta uma população potencialmente 
ativa de $64,6 \%$ do total de habitantes, e tem ampliado consideravelmente sua oferta de emprego. (SEADE, 1997)

O município é abastecido com água pela SABESP e segundo seus parâmetros de controle sanitário, $83 \%$ da população da localidade recebe água de boa qualidade. (Prefeitura de Taboão da Serra, 1998)

Apenas $31 \%$ da população do município é atendida com redes de coleta de esgotos domésticos que não são tratados e lançados em córregos da região.(Prefeitura de Taboão da Serra, 1998)

Segundo a Fundação SEADE, no ano de 1991, a taxa de analfabetismo da população adulta foi de $11,41 \%$ e a taxa de analfabetismo entre as mulheres em idade fértil foi de $7,23 \%$.

Os serviços de saúde são compostos por 08 unidades básicas de saúde, 01 unidade mista, 02 pronto socorros e 01 centro odontológico. O município possui também o Hospital Geral do Pirajussara com capacidade para 220 leitos.

Segundo o Censo Demográfico Brasileiro de 1991, Taboão da Serra apresentava, na época, 41.857 domicílios, sendo que $7,66 \%$ da população morava em favelas, localizadas em logradouros, dos quais cerca de $40 \%$ não são pavimentados. (SEADE, 1991) 
Tabela 11 - INDICADORES DEMOGRÁFICOS - 1998

\begin{tabular}{|l|r|}
\hline População Total & 195.926 \\
\hline Densidade Demográfica & $8.743,8$ \\
\hline Taxa Média de Crescimento Anual (TMCA) (\%) & 4,6 \\
\hline População Urbana & 192.242 \\
\hline Nascidos Vivos & 5.557 \\
\hline
\end{tabular}

Fonte: Fundação SEADE

Tabela 12 - INDICADORES SÓCIO-ECONÔMICOS - 1991

\begin{tabular}{|l|l|}
\hline Taxa de Analfabetismo População > 15 anos (\%) & 11,4 \\
\hline Domicílios com Abastecimento Adequado de Água (\%) & 83 \\
\hline Domicílios com Esgotamento Sanitário Adequado (\%) & 31 \\
\hline
\end{tabular}

Fonte: Secretaria Municipal de Saúde de Taboão da Serra

Tabela 13 - INDICADORES DE MORTALIDADE - 1998

\begin{tabular}{|l|c|}
\hline Taxa de Mortalidade Infantil & 16,6 \\
\hline Taxa de Mortalidade Geral (\%) & 5,7 \\
\hline Total de Óbitos & 1.090 \\
\hline
\end{tabular}

Fonte: Fundação SEADE 
Tabela - 14 DOENÇAS DE NOTIFICAÇÃO COMPULSÓRIA - 1994

\begin{tabular}{|l|c|}
\hline Esquistossomose & 172 \\
\hline Tuberculose & 146 \\
\hline Hepatites & 94 \\
\hline Rubéola & 45 \\
\hline Doença Meningocócica & 21 \\
\hline Hanseníase & 08 \\
\hline Leptospirose & 08 \\
\hline Sarampo Hospitalar & 01 \\
\hline
\end{tabular}

Fonte: Secretaria Municipal de Saúde de Taboão da Serra

Os indicadores de saúde de Taboão da Serra demonstram que a média não está muito distante das encontradas nos demais municipios do país.

Apesar da Taxa de mortalidade infantil apresentar um valor de $16,58 \%$ e a Taxa de mortalidade geral de $5,67 \%$, este município ainda tem muito que investir na área sanitária. As doenças crônico-degenerativas e a violência urbana são os principais problemas de saúde da região Metropolitana, principalmente quando se verifica uma população urbana de 192.242 habitantes em 1998.

Com referência à morbidade, existem ainda hoje muitas doenças preveniveis, seja por vacinação ou pela ampliação da responsabilidade pela vigilância sanitária e epidemiológica, viabilizando um sistema de ações de saúde voltadas para a coletividade. 


\subsection{Procedimentos}

Na coleta de dados utilizou-se o método da observação e o questionário, com questões abertas e fechadas. Fez-se o uso desta metodologia pelas vantagens que apresentam, pelo fato de ser um instrumento que fornece as respostas desejadas mais rapidamente e simultaneamente a várias pessoas. Outra vantagem considerada na escolha deste método devido o próprio entrevistado responder por escrito, não havendo riscos de distorções nas respostas e possibilitando maior tempo para registrar suas opiniões.

Porém, um inconveniente encontrado nesta metodologia foi o reduzido número de questionários que retornaram.

A tabulação dos dados obtidos foi feita através da formulação de categorias específicas para cada tipo de questão, classificando os dados encontrados nas variáveis aplicadas nos questionários.

A escolha dos municípios foi considerando os aspectos semelhantes entre si, o seu porte, médio, ou seja, municipios "dormitórios", com pequena arrecadação per capita, com até 200.000 habitantes. Possuem características epidemiológicas e populacionais semelhantes e pertencem à região metropolitana de São Paulo. A diferença encontrada foi o de desenvolvimento, no processo de 
implantação do SUS, ou seja, o municipio de Ferraz de Vasconcelos encontra-se habilitado em Gestão Plena de Atenção Básica, a partir de 5 de janeiro de 1999 e Taboão da Serra no tipo de Gestão Plena do Sistema Municipal, a partir de 4 de maio de 1998. 


\section{RESULTADOS}

As novas diretrizes de saúde propostas a partir da Constituição de 1988, destacando-se as chamadas Leis Orgânicas $n^{\circ} 8.080 / 90$ e 8.142/90 e atualmente, a NOB-SUS 01/96, mencionam os requisitos necessários para o município estar habilitado na condição de "Gestão Plena da Atenção Básica" ou "Gestão Plena do Sistema Municipal". Estes requisitos são importantes instrumentos que os gestores dos municípios possuem na condução de seu compromisso com a população.

Para que o município seja habilitado na gestão Plena da Atenção Básica é necessário respeitar os seguintes requisitos:

a) Comprovar o funcionamento do Conselho Municipal de Saúde (CMS).

b) Comprovar a operação do Fundo Municipal de Saúde (FMS).

c) Apresentar o Plano Municipal de Saúde e comprometer-se a participar da elaboração e da implementação da Programação Pactuada e Integrada (PPI) da unidade federada, bem como da alocação de recursos expressa na programação.

d) Comprovar capacidade técnica e administrativa e condições materiais para o exercicio de suas responsabilidades e prerrogativas quanto à contratação, ao pagamento, ao controle e à auditoria dos serviços sob sua gestão. 
e) Comprovar a dotação orçamentária do ano e o dispêndio realizado no ano anterior, correspondente à contrapartida de recursos financeiros próprios do Tesouro Municipal, de acordo com a legislação em vigor.

f) Formalizar junto ao gestor estadual, com vistas à Comissão Intergestores Bipartite (CIB), após aprovação pelo CMS, o pleito de habilitação, atestando o cumprimento dos requisitos relativos à condição de gestão pleiteada.

g) Dispor de médico formalmente designado como responsável pela autorização prévia, controle e auditoria dos procedimentos e serviços realizados.

h) Comprovar a capacidade para o desenvolvimento de ações de vigilância sanitária.

i) Comprovar a capacidade para o desenvolvimento de ações de vigilância epidemiológica.

j) Comprovar a disponibilidade de estrutura de recursos humanos para supervisão e auditoria da rede de unidades, dos profissionais e dos serviços realizados.

Os municípios habilitados na Gestão Plena do Sistema Municipal, devem cumprir além dos requisitos da Gestão Plena da Atenção Básica os seguintes: 
a) Participar da elaboração e da implementação da PPI da Unidade Federada, bem assim da alocação de recursos expressa na programação.

b) Comprovar capacidade técnica e administrativa e condições materiais para o exercício de suas responsabilidades e prerrogativas quanto à contratação, ao pagamento, ao controle e à auditoria dos serviços sob sua gestão, bem como avaliar o impacto das ações do Sistema sobre a saúde dos seus munícipes.

c) Formalizar, junto ao gestor estadual com vistas à CIB, após aprovação pelo CMS, o pleito de habilitação, atestando o cumprimento dos requisitos específicos relativos à condição de gestão pleiteada.

d) Dispor de médico formalmente designado pelo gestor como responsável pela autorização prévia, controle e auditoria dos procedimentos e serviços realizados.

e) Apresentar o Plano Municipal de Saúde, aprovado pelo CMS, que deve conter as metas estabelecidas, a integração e articulação do municipio na rede estadual e respectivas responsabilidades na programação integrada do estado, incluindo detalhamento da programação de ações e serviços que compõem o sistema municipal, bem como os indicadores mediante dos quais será efetuado o acompanhamento.

f) Comprovar o funcionamento de serviço estruturado de vigilância sanitária e capacidade para o desenvolvimento de ações de vigilância sanitária. 
g) Comprovar a estruturação de serviços e atividades de vigilância epidemiológica e de controle de zoonoses.

h) Apresentar o Relatório de Gestão do ano anterior à solicitação do pleito, devidamente aprovado pelo CMS.

i) Assegurar a oferta, em seu território, de todo o elenco de procedimentos cobertos pelo Piso de Atenção Básica (PAB) e, adicionalmente, de serviços de apoio diagnóstico em patologia clínica e radiologia básicas.

j) Comprovar a estruturação do componente municipal do Sistema Nacional de Auditoria (SNA).

k) Comprovar a disponibilidade de estrutura de recursos humanos para supervisão e auditoria da rede de unidades, dos profissionais e dos serviços realizados.

O município de Ferraz de Vasconcelos está habilitado na Gestão Plena da Atenção Básica e o município de Taboão da Serra na Gestão Plena do Sistema Municipal.

Para o reconhecimento da Unidades Básicas de Saúde foi elaborado um roteiro de identificação das Unidades, onde todas foram visitadas, nos dois municípios em estudo. (Anexo 1).

Como já foi citado no capítulo Metodologia, para o desenvolvimento desta pesquisa foram aplicados questionários, para coletar dados que 
permitissem levantar a situação da equipe de enfermagem, para a análise do trabalho desenvolvido. Anexos 2 e 3

\subsection{Identificação das UBS}

Tabela 15 - Unidades Básicas de Saúde do Município de Ferraz de Vasconcelos, segundo horário de funcionamento, 1999.

\begin{tabular}{l|l}
\hline UNIDADE BASICA DE SAÚDE & HORARIO DE FUNCIONAMENTO \\
\hline CDHU & $7: 00 \mathrm{~h}$ às $17: 00 \mathrm{~h}$ \\
\hline CSII & $7: 00 \mathrm{~h}$ às $17: 00 \mathrm{~h}$ \\
\hline Jardim Castelo & $7: 00 \mathrm{~h}$ às $17: 00 \mathrm{~h}$ \\
\hline Jardim Margarida & $7: 00 \mathrm{~h}$ às $17: 00 \mathrm{~h}$ \\
\hline Jardim Rosana & $7: 00 \mathrm{~h}$ às $17: 00 \mathrm{~h}$ \\
\hline Rolando Kaese Módel & $7: 00 \mathrm{~h}$ às $16: 45 \mathrm{~h}$ \\
\hline Vila Santo Antonio & $7: 00 \mathrm{~h}$ às $17: 00 \mathrm{~h}$ \\
\hline Vila Såo Paulo & $7: 00 \mathrm{~h}$ às $17: 00 \mathrm{~h}$ \\
\hline
\end{tabular}


Tabela 16 - Unidades Básicas de Saúde do Município de Taboão da Serra, segundo horário de funcionamento, 1999.

\begin{tabular}{l|c}
\hline UNIDADE BÁSICA DE SAÚDE & HORÁRIO DE FUNCIONAMENTO \\
\hline Dr Akira Tada & $7: 00$ às $17: 00 \mathrm{~h}$ \\
\hline Jardim Helena & $7: 00 \mathrm{~h}$ às $21: 00 \mathrm{~h}$ \\
\hline Jardim Margarida & $7: 00 \mathrm{~h}$ às $17: 00 \mathrm{~h}$ \\
\hline Jardim Suiná & $7: 00 \mathrm{~h}$ às $21: 00 \mathrm{~h}$ \\
\hline Parque Pinheiros & $7: 00 \mathrm{~h}$ às $21: 00 \mathrm{~h}$ \\
\hline Santa Cecilia & $7: 00 \mathrm{~h}$ às $21: 00 \mathrm{~h}$ \\
\hline Santo Onofre & $8: 00 \mathrm{~h}$ às $20: 00 \mathrm{~h}$ \\
\hline Silvio Sampaio & $7: 00 \mathrm{~h}$ às $17: 00 \mathrm{~h}$ \\
\hline
\end{tabular}

Os municípios estão equipados com oito UBS em cada um deles, distribuidos por conglomerados de tamanho significativo, bairros populosos, e em alguns deles atendem, além da população local, usuários de outros municipios e de outras UBS.

Observou-se inicialmente uma distinção nos atendimentos na área da saúde dos municípios, no que se refere ao horário. Em Ferraz de Vasconcelos o atendimento se realiza em dois turnos, enquanto que em Taboão da Serra observa-se que grande parte funciona em três turnos. Encontrou-se em Taboão da Serra um contingente maior de pessoal de enfermagem. 
Tabela 17 - Atividades Básicas de Enfermagem Desenvolvidas por Unidade de Saúde de Ferraz de Vasconcelos no ano de 1999

\begin{tabular}{|c|c|c|c|c|c|c|c|c|}
\hline Atividade & CDHU & CSII & $\begin{array}{l}\text { Jd. } \\
\text { Castelo }\end{array}$ & $\begin{array}{l}\text { Jd. } \\
\text { Margarida }\end{array}$ & $\begin{array}{l}\text { Jd. } \\
\text { Rosana }\end{array}$ & $\begin{array}{l}\text { Rolando } \\
\text { Kaese } \\
\text { Módel }\end{array}$ & $\begin{array}{l}\text { Vila } \\
\text { Santo } \\
\text { Antonio }\end{array}$ & $\begin{array}{l}\text { Vila } \\
\text { São } \\
\text { Paulo }\end{array}$ \\
\hline Imunização & Não & Sim & Sim & Sim & Sim & Sim & Sim & Sim \\
\hline Curativo & Não & Sim & Sim & Sim & Sim & Não & Sim & Sim \\
\hline $\begin{array}{l}\text { Medicação/ } \\
\text { Inalação }\end{array}$ & Sim & Sim & Sim & Sim & Sim & Sim & Sim & Sim \\
\hline $\begin{array}{l}\text { Coleta de } \\
\text { Material }\end{array}$ & Sim & $\mathrm{Sim}$ & $\mathrm{Sim}$ & $\mathrm{Sim}$ & Sim & Sim & $\mathrm{Sim}$ & $\mathrm{Sim}$ \\
\hline $\begin{array}{l}\text { Esterilizaçã } \\
\text { o de } \\
\text { Material }\end{array}$ & Não & Sim & Sim & Sim & Sim & Não & Sim & Sim \\
\hline $\begin{array}{l}\text { Pré e Pós } \\
\text { Consulta }\end{array}$ & Sim & Sim & Sim & Sim & Sim & $\mathrm{Sim}$ & Sim & $\mathrm{Sim}$ \\
\hline Grupos & Não & Sim & Sim & Sim & Sim & Sim & Sim & Sim \\
\hline $\begin{array}{l}\text { Visita } \\
\text { Domiciliar }\end{array}$ & Năo & Sim & Sim & Sim & Não & Năo & Sim & Sim \\
\hline
\end{tabular}


Tabela 18 - Atividades Básicas de Enfermagem por Unidade de Saúde de Taboão da Serra no ano de 1999.

\begin{tabular}{|c|c|c|c|c|c|c|c|c|}
\hline Atividade & $\begin{array}{l}\text { Dr. Akira } \\
\text { Tada }\end{array}$ & $\begin{array}{l}\text { Jardim } \\
\text { Helena }\end{array}$ & $\begin{array}{l}\text { Jardim } \\
\text { Margarida }\end{array}$ & $\begin{array}{l}\text { Jardim } \\
\text { Suiná }\end{array}$ & $\begin{array}{l}\text { Parque } \\
\text { Pinheiros }\end{array}$ & $\begin{array}{l}\text { Santa } \\
\text { Cecilia }\end{array}$ & $\begin{array}{l}\text { Santo } \\
\text { Onofre }\end{array}$ & $\begin{array}{l}\text { Silvio } \\
\text { Sampaio }\end{array}$ \\
\hline Imunização & Sim & Sim & Sim & Sim & Sim & Sim & Sim & Sim \\
\hline Curativo & Não & Sim & Sim & Sim & Sim & Sim & Sim & Sim \\
\hline $\begin{array}{l}\text { Medicação } \\
\text { Inalação }\end{array}$ & Não & Sim & Sim & Sim & Sim & Sim & Não & Sim \\
\hline $\begin{array}{l}\text { Coleta de } \\
\text { Material }\end{array}$ & Sim & Sim & Sim & Sim & Sim & Sim & Sim & Sim \\
\hline $\begin{array}{l}\text { Esterilização } \\
\text { de Material }\end{array}$ & Sim & Sim & Sim & $\mathrm{Sim}$ & Sim & Sim & Sim & Sim \\
\hline $\begin{array}{l}\text { Pré e Pós } \\
\text { Consulta }\end{array}$ & Não & $\mathrm{Sim}^{*}$ & $\mathrm{Sim}^{\star}$ & Não & Não & Sim* & Não & $\operatorname{Sim}^{\star}$ \\
\hline Grupos & Sim & Sim & Sim & Sim & Não & Sim & Sim & Sim \\
\hline $\begin{array}{l}\text { Visita } \\
\text { Domiciliária }\end{array}$ & Sim & Sim & Sim & Sim & Sim & Sim & Sim & Sim \\
\hline
\end{tabular}

$\mathrm{Na}$ identificação das UBS foram levantadas também as principais atividades de enfermagem oferecidas. Constatamos que algumas ações prestadas em um município, não são desenvolvidas no outro. 
Tabela 19 - Categorias de enfermagem e número de trabalhadores nos Municipios de Ferraz de Vasconcelos e Taboão da Serra, quantidade por categoria, 1999.

\begin{tabular}{l|c|c}
\hline CATEGORIA & FERRAZ DE VASCONCELOS & TABOÅO DA SERRA \\
\hline Enfermeiro & 6 & 17 \\
\hline Auxiliar de Enfermagem & 29 & 86 \\
\hline Atendente de Enfermagem & 22 & 4 \\
\hline Total & 57 & 111 \\
\hline
\end{tabular}

Tabela 20 - Profissionais médicos, segundo número e especialidade, por Municipio, 1999.

\begin{tabular}{l|c|c}
\hline ESPECLALIDADE & FERRAZ DE VASCONCELOS & TABOÃO DA SERRA \\
\hline Clínica Médica & 7 & 16 \\
\hline Ginecologia e Obstetricia & 10 & 9 \\
\hline Pediatria & 13 & 19 \\
\hline cardiologia & 1 & $\mathrm{~N}$ \\
\hline psiquiatria & 1 & 1 \\
\hline Total & 32 & 45 \\
\hline
\end{tabular}

Observa-se que o quantitativo de profissional médico se equivale no total nos dois municipios, notando apenas que os números de clínico geral e de pediatria são maiores em Taboão da Serra.

Quanto aos demais profissionais de nivel universitário, os municípios contam com dentistas, psicólogos, fonoaudiólogos, terapeutas ocupacionais, assistentes sociais e fisioterapeutas, nas diversas UBS. 
Participaram deste processo, os enfermeiros e auxiliares de enfermagem, os dois componentes da enfermagem que atuam nas Unidades Básicas de Saúde, nestes municípios.

Para uma melhor compreensão das etapas que compõem este capítulo, subdividiram-se as questões do questionário aplicado para enfermeiros nos seguintes tópicos:

1.Identificação do enfermeiro, abordando neste item sua especialidade, suas funções e atividades de rotina na UBS; (Anexo 2)

Opiniões sobre:

- O Sistema Único de Saúde;

-Os Recursos Humanos;

-A Unidade Básica de Saúde.

Do mesmo modo, executamos para os auxiliares de enfermagem (Anexo 3), aos quais além de uma breve identificação, abordou-se sobre os temas:

- O seu trabalho na Unidade;

- Os recursos humanos da Unidade;

- O Sistema Único de Saúde - SUS;

-A Unidade Básica de Saúde. (Anexo 3) 
Os resultados a seguir apresentados correspondem ao expresso pelos entrevistados, individualmente, esses dados são passiveis de outras análises de discurso coletivo que não são objeto deste trabalho.

\subsection{Identificação dos Enfermeiros de Ferraz de Vasconcelos}

Este municipio conta com um contingente de seis enfermeiros, sendo cinco do sexo feminino e um do sexo masculino, com idade variando entre 27 anos a 45 anos.

Alguns profissionais possuem em sua formação habilitações ou especializações em Administração Hospitalar na Fundação Getulio Vargas FGV, Habilitação em Saúde Pública, Licenciatura Plena e Pedagogia na Universidade Mogi das Cruzes e Especialização em Saúde Pública na Faculdade Cruzeiro do Sul.

O tempo em que trabalham na Instituição:

Até 1 ano: 2

De 1 ano a 5 anos: 1

Mais de 5 anos: 1

Solicitou-se que descrevessem as suas atividades rotineiras nas UBS, os mais referidos foram: imunizações, coleta de material para 
laboratório, assistência na saúde mental, clínica médica, pediatria, ginecologia, odontologia, medicações, entrega de medicamentos, inaloterapia, grupos de orientações em hipertensão, diabetes, educação em saúde, orientação de pacientes e funcionários, atendimento de enfermagem na puericultura e coleta de Papanicolaou e administração da área de enfermagem.

Vinculada a esta questão, solicitou-se que mencionassem o maior tempo gasto em suas funções, todos foram unânimes em afirmar que, são as ações assistenciais são aquelas que consomem maior tempo. Referem que: "as informações/orientações ou procedimentos requerem mais tempo, pois você está em contato direto com a população"; "as atividades assistenciais, requerem mais dedicação e cuidados"; "grupos e puericultura".

\subsection{Sobre o Sistema Único de Saúde}

Nenhum dos enfermeiros relatou envolvimento com as decisões politicas tomadas pela secretaria municipal de saúde.

Sobre o processo político de saúde do país, solicitou-se que expressassem o que entendem por Sistema Único de Saúde. As respostas obtidas foram: "é um Sistema que abrange todas as necessidades da 
população de uma forma unificada, sem separações"; "centralização da saúde a nivel de verbas e rotinas".

Solicitou-se também que opinassem sobre as mudanças sentidas após a implantação do Sistema Único de Saúde. Apenas um deles respondeu "os custos chegam mais rápido, viabilizando nosso trabalho", os demais não responderam a esta questão.

Sobre os pontos positivos após a implantação do Sistema Único de Saúde, "ainda está muito recente, não tenho condições de apontar pontos positivos".

Sobre os pontos negativos após a implantação do Sistema Único de Saúde, "o ponto negativo é que apesar de estar no papel, a prática ainda não chega até nós".

Sobre o papel do Conselho Municipal de Saúde, "é a participação administrativa, cobrando dos administradores a aplicação correta das verbas de acordo com as necessidades da região", "para trabalhar em soluções de melhorias para a saúde".

Perguntou-se ainda sobre os representantes das comunidades onde trabalham, e nenhum deles respondeu esta questão. 
Da mesma forma, sobre os representantes das UBS no Conselho Municipal de Saúde, eles não responderam; apenas um disse que "não tem nenhum representante, porque esta Unidade é nova, estamos montando os trabalhos prioritários e aguardamos o convite".

\subsubsection{Pessoal de Enfermagem e o Processo de Trabalho}

$\mathrm{Na}$ quantificação dos funcionários, o município de Ferraz de Vasconcelos conta com seis enfermeiros, 29 auxiliares de enfermagem e 22 atendentes de enfermagem.

Quando solicitamos aos enfermeiros a opinião a respeito do contingente numérico de recursos humanos, citam que ele não é suficiente, "porque a demanda da população é muito maior"; "porque a área de abrangência é grande, não respondem às necessidades mais prementes"; "Porque muitas vezes não é possível dar a atenção necessária aos clientes".

Os principais problemas em relação aos recursos humanos das Unidades apontados são:

- "pessoal capacitado, qualificado, porém poucos funcionários"

- "estamos precisando abrir serviços tipo: curativos, atendimento médico no período da tarde, planejamento familiar" 
- "não existe transposição de cargos para atendentes de enfermagem que fizeram o curso. Desvio de função"

- "seria necessário que ficasse um funcionário para cada atividade oferecida na Unidade"

Quanto às mudanças sentidas em relação aos recursos humanos da Unidade, tanto qualitativas quanto quantitativas, um refere que: "estamos precisando abrir serviços tipo: curativos, atendimento médico no período da tarde e planejamento familiar".

A atenção aos recursos humanos em termos de seu desenvolvimento através de reciclagens e treinamentos não é dada, um deles alega que "não, pois não temos espaço físico", outro diz que "são raros os treinamentos e cursos".

\subsubsection{A Unidade Básica de Saúde no Desenvolvimento do Trabalho}

Quanto ao espaço físico para o desenvolvimento do trabalho da enfermagem, alguns consideram que "a Unidade tem um bom e amplo espaço físico, inclusive partes que não são utilizadas"; "a Unidade não tem estrutura para saúde, apesar do prédio ser novo, acredito que não foi consultado um profissional da saúde na construção" e outro refere que "deveria ter uma sala maior para grupos". 
Sobre os equipamentos das UBS, "os equipamentos são antigos e obsoletos" (esta UBS é nova, inaugurada no final de 1998, e colocaram equipamentos e mobiliários de outras unidades que não estavam sendo utilizados e muitos deles continuam armazenados nesta Unidade); "os equipamentos são bons e funcionantes"; "deixa a desejar, pois falta manutenção dos equipamentos"; "faltam armários, cadeiras e mesas".

O sistema de informação do município para as UBS é feito através de reuniōes, telefonemas, ofícios, cartas e impressos, mas sem periodicidade.

Os principais obstáculos citados para o bom funcionamento da UBS foram "a falta de materiais de consumo"; "falta de medicamentos"; "falta de profissionais, principalmente enfermeiros".

Sobre a área de abrangência das UBS "ainda não recebi o mapa de área de abrangência, sinto que o atendimento cobre até pessoas de São Paulo pois estamos na divisa de município"; "deveria ter uma área de abrangência para cada UBS atender a sua clientela"; "me parece que somente são atendidas pessoas que moram neste bairro, onde está localizada a UBS"; "confuso, pois esta área é grande demais para um único posto". 
Os critérios para o acesso dos usuários na UBS são: "morar na área de abrangência e ter a vaga para o usuário ser atendido mesmo sendo de outra região"; "apresentação e comprovação de documentos"; "normalmente não temos critérios, usamos de bom senso, já que esta Unidade ainda não tem registro".

Relatam que as atividades educativas desenvolvidas nas UBS são: "Grupos: Planejamento Familiar, Aleitamento Materno, Diabetes e Hipertensão"; "Educação em saúde, falando sobre doenças de notificação compulsória, higiene, doenças crônicas, métodos contraceptivos e política de saúde"; "Serviço de orientações à população". 


\subsection{Identificação dos Enfermeiros de Taboão da Serra}

O município de Taboão da Serra conta com uma equipe composta de 17 enfermeiras, todas do sexo feminino.

A idade das enfermeiras:

Até 30 anos: 1

De 30 a 40 anos: 6

Mais de 40 anos: 1

Algumas destas profissionais apresentam habilitações, especializações, aprimoramentos e outros cursos tais como: Aprimoramento em Saúde - Coletiva pelo Instituto de Saúde voltada para o aleitamento materno, Habilitação em Saúde Pública, Licenciatura Plena na Universidade de Mogi das Cruzes, Especialização em Enfermagem do Trabalho na Faculdade São Camilo, Especialização em Saúde Pública pela Universidade de Ribeirão Preto e Obstetriz pela Faculdade São Camilo (Antiga Faculdade São José).

O tempo de vínculo com as instituições onde atuam:

De 1 a 2 anos: 3

De 2 a 3 anos: 2

Mais de 3 anos: 1 
Tabela 21 - Funções e Atividades desenvolvidas pelas enfermeiras de Taboão da Serra, 1998

\begin{tabular}{|c|c|}
\hline ATNIDADES & \\
\hline Atendimento ao Público & $\begin{array}{l}\text { Recepção; Triagem de pacientes; Orientação para exames; } \\
\text { Encaminhamentos }\end{array}$ \\
\hline Vigilância Epidemiológica & $\begin{array}{l}\text { Bloqueios; Visita Domiciliária; Boletins Semanais e Mensais; Busca Ativa } \\
\text { de Casos; Programa de Tuberculose Supervisionado }\end{array}$ \\
\hline Vacinação & $\begin{array}{l}\text { Manutenção da Rede de Frio; Supervisão da Aplicação; Orientação aos } \\
\text { Pais; Boletim Mensal de Vacinas; Convocação de Faltosos; Campanha } \\
\text { de Vacinaçăo; Coordenação da Sala de Vacinas }\end{array}$ \\
\hline $\begin{array}{l}\text { Supervisåo dos Auxiliares de } \\
\text { Enfermagem }\end{array}$ & $\begin{array}{l}\text { Sala de Vacinas; Curativos; Drenagem de Abcesso; Administraçăo de } \\
\text { Medicamentos; Coleta de Material para Laboratório; Coleta de } \\
\text { Papanicolaou; Retirada de Pontos; Inalaçőes; Limpeza, Desinfecção e } \\
\text { Esterilizaçăo de Material; Coleta para o Exame PKU (Teste do pezinho) }\end{array}$ \\
\hline Atendimento Ambulatorial & $\begin{array}{l}\text { Pediatria; Ginecologia e Obstetrícia; Clínica Geral; Psiquiatria; } \\
\text { Imunizaçōes; Psicologia; Terapia Ocupacional }\end{array}$ \\
\hline Grupos de Orientação & Gestantes; Planejamento Familiar; Amamentaçåo \\
\hline Orientaçס̄es Individuais & Diabéticos; Hipertensos; Ginecologia; Psiquiatria \\
\hline Farmácia e Almoxarifado & Supervisão de Estoque; Solicitação de Materiais \\
\hline Manutenção da Unidade & $\begin{array}{l}\text { Supervisão do Pessoal de Limpeza; Solicitação de Consertos na Área } \\
\text { Física e Equipamentos }\end{array}$ \\
\hline Consulta de Enfermagem & Aleitamento Materno \\
\hline $\begin{array}{l}\text { Coleta de Material para } \\
\text { Laboratório }\end{array}$ & $\begin{array}{l}\text { Supervisão do Agendamento; Organização da Coleta de Material; } \\
\text { Punção para Coleta }\end{array}$ \\
\hline
\end{tabular}

Solicitou-se que, vinculada à questão sobre as funções e atividades que os enfermeiros exercem, opinassem a respeito do uso de seu tempo na Unidade entre as atividades administrativas e assistenciais: "administrativas e assistenciais, na verdade o que ocorre é uma sobrecarga do enfermeiro, que tem que se dividir entre as duas funções: ao mesmo tempo que estou avaliando um ferimento (ferida) de um paciente diabético, tenho que 
resolver problemas relacionados a materiais, pessoal, agenda médica e vigilância.

"O enfermeiro é visto pela administração local (Secretaria da Saúde), pelos colegas profissionais de saúde (médicos, psicólogos), pelos outros funcionários e também pela população como o 'resolve tudo'. Desta forma, nosso trabalho fica prejudicado, a qualidade cai, ficamos frustradas, pois acabamos não tendo tempo para projetos e atividades mais próximas à comunidade". "Eu procuro balancear as atividades, mas acabo atuando mais administrativamente, por necessidade da unidade"; "administrativa porque trabalhamos com prevenção e coleta de dados"; "administrativa, devido ao cargo"; "administrativa, falta de funcionário administrativo"; "administrativas, embora as assistenciais exijam mais tempo, a atividade administrativa sempre é cobrada mês a mês e dela depende o funcionamento da Unidade"; "administrativa, devido à grande quantidade de atividades a serem realizadas"; "as duas, talvez mais a administrativa, devido ao preenchimento de fichas e embora esteja sempre acompanhado de uma atividade assistencial".

Quanto à participação nas decisões políticas da Unidade, todas não se envolvem, uma refere que "estas, aliás, são sempre tomadas sem uma participação da comunidade", e duas participam, pois estão em cargos de direção das UBS. 


\subsubsection{Sobre o Sistema Único de Saúde}

Nas questões referentes ao significado do Sistema de Único de Saúde, relatam opiniões tais como: "é o Sistema Único de Saúde que surge enquanto idéia e política de saúde na $9^{a}$ Conferência de Saúde"; "é o atendimento integrado pelas instituições públicas para prestar assistência primária, secundária e terciária"; "saúde para todos nas três áreas de assistência, é um sistema de referência e contra-referência"; "atendimento integrado das instituições públicas, prestando assistência nos três níveis, dependendo da necessidade do usuário"; "é um sistema onde todo cidadão tem direito de ser atendido, principalmente nas especialidades, facilitando os encaminhamentos".

Foi ainda solicitado que expressassem suas opiniões a respeito das mudanças ocorridas após a implantação do Sistema Único de Saúde: "tivemos mais locais de referência, embora sinta que haja necessidade de reestruturação deste Sistema para melhorar e aumentar estes locais"; "aumento das instituições básicas, facilitando o acesso do usuário e assistência preventiva (pré-natal, controle de doenças crônicas degenerativas, imunização, puericultura e saúde bucal); "atende ao paciente sem exigência de comprovante se tem ou não direito ao INSS"; "fácil acesso dos usuários à assistência preventiva (especialidades), não somente 
tratamento curativo. O que uma instituição tem, ajuda a outra que não tem (troca de serviços).

Do mesmo modo, foi solicitado que destacassem os pontos positivos após a implantação do SUS: "o acesso fácil aos serviços de saúde: direcionou melhor 0 encaminhamento para as mais diversas especialidades"; "acho que houve mais expansão das unidades de saúde, trazendo os serviços de saúde pelo menos nas áreas de atendimento primário para mais próximo da população"; "integração com a população através, de sociedades amigos de bairros para direcionar o atendimento, pois o acesso às UBS tornou-se mais fácil".

Sobre os pontos negativos relatam que: "a melhora não foi acentuada e existem algumas dificuldades de encaminhamentos e a espera está para longe e nem para todos os exames conseguimos vagas, gerando muita ansiedade para nós e os pacientes"; "a regionalização dos serviços e a referência e contra-referência limitadas"; "falta de: medicamentos básicos para Programas, melhores aplicações em investimentos nos programas de saúde pública por parte dos poderes públicos e contratação de profissionais da área de saúde"; "algumas especialidades são limitadas e com a regionalização ficou difícil procurar serviços fora de área que foi regionalizada". 
Quanto ao tema referente ao papel do Conselho Municipal de Saúde: "O CMS deve possuir um papel orientador, quando aponta, sugere quais as necessidades locais na saúde. Papel fiscalizador, quando exige que as reivindicações sejam atendidas, papel regulamentador, quando atua na câmara de vereadores ou em outras instâncias administrativas, no sentido de fazer efetivar as necessidades apontadas pelo CMS"; "levantar junto à comunidade os principais problemas, dificuldades e traçar junto com a Secretaria de Saúde metas de atendimento à população"; "União da administração pública juntamente com representantes da sociedade organizada, que procurassem soluções para os problemas de cada Unidade de Saúde"; "seria participar ativamente das decisões e planejamentos referentes à saúde (de uma forma mais ampla) de sua comunidade"; "supervisionar as reivindicações de saúde necessárias à comunidade local, apontar necessidades não atendidas, problemas na assistência e atendimento. Conferir a utilização das verbas referentes à saúde"; "melhoria no atendimento à saúde"; "não temos esse conselho no nosso município".

Questionadas sobre a participação dos servidores da área da saúde no CMS, relatam que não há no momento nenhum representante das unidades onde trabalham, e algumas confirmam a participação de funcionários e observam que: "por indicação do Sr. Prefeito de Taboão da Serra"; "foram nomeados pelo Secretário da Saúde"; "é o mesmo que representa a comunidade. Foi escolhido pela Secretaria da Saúde do Município" 


\subsubsection{Pessoal de Enfermagem e o Processo de Trabalho}

O município de Taboão da Serra, conta com 17 enfermeiros, 86 auxiliares de enfermagem e 4 atendentes de enfermagem.

A maioria das enfermeiras não acha suficiente o número de funcionários existentes no municipio, no atendimento das UBS. Alegam que: "em primeiro lugar, devido ao horário de funcionamento em três períodos, dessa forma, o horário noturno e vespertino ficam muito desfalcados, em segundo lugar, devido a alta demanda de atendimentos", "porque a nossa unidade tem carga horária de 6 horas (por turno) e tem períodos em que temos mais funcionários disponiveis do que em outros"; "com esta quantidade não se consegue desenvolver atividades como grupos educativos à comunidade (os que existem não são suficientes)"; "seria necessário mais funcionários para cobertura de férias, folgas e licenças". Já outras delas consideram que o número é suficiente: "nossa UBS divide espaço com um PS, o qual realiza todos os procedimentos, a UBS atende (apenas) sala de imunizações, coleta de sangue, coleta de citologia oncótica e investigações epidemiológicas"; "sim, porque as funções de enfermagem são bem divididas, ficando cada um responsável por um setor de atendimento, e é possível cobrir faltas".

Principais problemas em relação aos recursos humanos na UBS: 
- "número de funcionários abaixo da necessidade, falta de reciclagem/treinamento, de plano de carreira e de mecanismos de avaliação";

- "a unidade teria diversas atividades no período da tarde se tivesse um número maior de pessoal";

- "no momento, estamos desfalcados de pessoal administrativo";

- "no quantitativo estou satisfeita, os funcionários existentes são treinados para atuarem nas diversas áreas, mas faltam salas adequadas e em quantidade";

- "mais enfermeiros para que possa dar mais atenção às atividades educativas tais como: gestantes, puericultura, adolescentes e idosos. Contratar também mais recepcionistas, serviço social, agente administrativo e auxiliar de limpeza".

Quanto às mudanças ocorridas em relação aos recursos humanos após a implantação do SUS: "houve algumas mudanças, a principal delas foi a quantitativa"; "funcionários públicos estadual e municipal começaram a trabalhar na mesma Unidade"(aumento ou diminuição dos recursos humanos em algumas unidades) e "houve remanejamento de funcionários, nas diversas áreas, diminuindo o quadro de funcionários em algumas UBS".

No processo de desenvolvimento de recursos humanos, questionamos a respeito da oferta de treinamentos, reciclagens, etc, e acusam que: "oferecem, para enfermeiros, auxiliares de enfermagem, Curso 
de Larga Escala para os demais, principalmente os da área da saúde" e, "treinamentos esporádicos oferecidos pela vigilância epidemiológica para enfermeiros e mais raramente para auxiliares de enfermagem".

\subsubsection{A Unidade Básica de Saúde no Desenvolvimento do Trabalho}

Quanto ao espaço físico da UBS, observam alguns pontos positivos "adequado para o atendimento atual. Possuímos salas individuais para Terapia Ocupacional, Fonoaudiologia e Psicologia, dividimos a sala de grupos com atendimento clínico em horários diferentes. As salas de imunização e coleta são exclusivas para tais atividades"; "adequado, os consultórios são amplos e arejados, há salas de reuniões e sanitários"; "ótimo, espaçoso, arejado e claro". Outras apontam pontos negativos tais como: "pequeno e muito barulhento"; "falta de salas para as atividades como vigilância epidemiológica, que acaba atendendo numa sala improvisada".

Os equipamentos das UBS são: "adequados para as necessidades da assistência prestada", "os equipamentos que temos na unidade são básicos e suficientes para o serviço que prestamos, no momento"; "os equipamentos são simples, há problemas, muitas vezes na reposição desses muito utilizados como estetoscópio e esfigmomanômetro"; "alguns equipamentos necessitam ser substituídos e outros necessitam de manutenção". 
Quando questionamos a respeito dos recursos técnicos das UBS alegam: "são profissionais experientes no atendimento da saúde pública, comprometidos e envolvidos no atendimento, facilitando assim a administração da Unidade"; "de acordo com o serviço que prestamos".

O sistema de informação da UBS com as outras unidades e a Secretaria da Saúde é feito através de reuniões mensais da Secretaria da Saúde com as UBS, comunicações internas, através de malotes que funcionam em dias alternados através de um motorista da Secretaria da Saúde, que passa por todas as unidades. É feito também através de telefonemas em casos mais urgentes, impressos, ofícios e relatórios.

Alguns obstáculos para o bom funcionamento das UBS foram apontados tais como: "falta de interesse de alguns, o não conhecimento de métodos de abordagem. O desconhecimento dos objetivos de uma UBS"; "na atual crise do pais, recursos financeiros para aquisição e/ou reposição de recursos materiais e humanos"; "a própria área física (muito barulho), a falta de investimento na área de recursos humanos e o desvio de função nós ficamos mais no tocar os serviços"; "falta de recursos humanos e equipamentos". Somente uma unidade considerou estar funcionando sem obstáculos: "Esta Unidade atua razoavelmente; diante do contexto todo, na medida do possivel, se consegue fazer um bom trabalho. A nossa equipe de vigilância epidemiológica é tida como a melhor do município". 
Os programas com a comunidade são feitos pelas enfermeiras intramuros através de: "grupos de gestantes, adolescentes, planejamento familiar, papanicolaou, hipertensos e hanseníase" e extra-muros, "específicos, por exemplo: orientação sobre enchentes, (domicílios e escolas) orientação sobre meningite".

Sobre a área de abrangência nas UBS, declaram que existe uma delimitação, dizem que: "facilita o fluxo do atendimento dentro da UBS logo que há o dimencionamento da população, não sobrecarregando os serviços prestados", "até certo ponto é bom, para delimitar a área e facilitar visitas domiciliárias. Por outro lado, acho que o usuário não entende essa coisa de passaporte (conta de luz para comprovar residência) para ser atendido" e "Tem que ser morador de Taboão da Serra, pertencer à área de abrangência estipulada pela Secretaria da Saúde"; "comprovar a residência".

Quanto às atividades educativas realizadas nas UBS: existe o "grupo de: Planejamento Familiar, onde é abordado o conhecimento da anatomia do sexo masculino e feminino; hipertensão, aborda como conhecer a parte fisiológica; asma e orientações na sala de vacinas e na coleta de papanicolaou" e "De forma indireta, nas visitas domiciliárias ou de forma quase individual, na pré-consulta nas consultas de tuberculosos e de outras doenças infecto-contagiosas". 
4.4 Identificação dos Auxiliares de Enfermagem de Ferraz de Vasconcelos

Este município conta com um total de 29 auxiliares de enfermagem, sendo que 18 deles responderam o questionário, destes 17 são do sexo feminino e um do sexo masculino.

$A$ idade variando entre:

De 30 a 40 anos: 5

De 40 a 50 anos: 7

Mais de 50 anos - 2

Os demais não preencheram o campo idade.

O tempo de contratação nos serviços de saúde do município:

até 1 ano: 5

De 2 a 5 anos: 9

Mais de 10 anos: 1 


\subsubsection{Trabalho na UBS}

Tabela 22 - Atividades Básicas Desenvolvidas pelos Auxiliares de Enfermagem de Ferraz de Vasconcelos, 1998

\begin{tabular}{|l|}
\hline ATNIDADES \\
\hline Administraçăo de Medicamentos \\
\hline Administração de Inalação \\
\hline Curativos \\
\hline Retirada de Pontos \\
\hline Triagem de Pacientes \\
\hline Vacinação \\
\hline Coleta de Material para Laboratório \\
\hline Orientaçōes para o Público \\
\hline Auxiliar nos Consultórios \\
\hline Esterilização de Material \\
\hline Limpeza dos Consultórios \\
\hline Preenchimento de Fichas no Balcão \\
\hline Controle de Pressão Arterial \\
\hline PKU (Teste do Pézinho) \\
\hline Agendamento de Consultas \\
\hline Palestras para a População \\
\hline Pré e Pós Consulta \\
\hline
\end{tabular}

Foi solicitado aos auxiliares de enfermagem que informassem se gostam de trabalhar na Unidade, "gosto, e fui muito bem recebida pelas colegas de trabalho, sendo uma Unidade pequena, dá para desempenhar bem a função" (esta funcionária está trabalhando nesta Unidade há 3 dias); outras responderam que: gostam da população com que lidam; seis responderam que gostam porque "fica perto da residência e trabalha na profissão que escolheu por isso se sentem muito bem"; duas responderam 
que é "porque já trabalho há muitos anos"; duas "pelos colegas, pelo ambiente agradável e o trabalho em si que é bom"; duas disseram que é "pelas amizades adquiridas pelo tempo de serviço (12 anos)".

Quando abordamos sobre os fatores que facilitam o trabalho do auxiliar de enfermagem nas unidades em que desempenham as suas atividades, oito responderam que é pelo "bom relacionamento com colegas de serviço e chefias"; três não responderam; "o contato direto com o público, podendo amenizar parte do sofrimento e necessidade da sua saúde após avaliação médica"; "não tenho dificuldade"; "horário e condução"; duas disseram que é quando "não falta material adequado para a enfermagem, durante o horário do trabalho e não faltar medicamentos".

A questão seguinte abordou sobre os fatores que dificultam 0 trabalho: "falta de adaptação pelo pouco tempo de trabalho e conhecimento do ambiente"; "dizer não ao usuário quando vem à procura da Unidade porque falta medicação, médico, material de consumo em geral"; "nenhuma dificuldade"; "a falta de funcionários específicos para cada serviço, como auxiliares de enfermagem"; "o número de funcionários diminuindo e salário não aumenta"; "nenhuma dificuldade, pois quando preciso tem pessoas capacitadas para me esclarecer".

Solicitamos então que fizessem sugestões para melhorar o serviço na Unidade e as que obtivemos foram as seguintes: quatro "regularizar a falta 
de material na Unidade"; "que não precisássemos cuidar também da parte burocrática (balcão), acaba ficando estressante"; "se tivesse pessoal para atendimento, medicamentos, recursos para os grupos"; "se tivesse maior espaço físico"; "só a secretaria sabe como sanar estes problemas"; "aumentar o quadro de funcionários e médicos (tais como: médico ginecologista, clínico geral, assistente social e psicólogo)"; "o problema abrange a rede de saúde por falta de verba e uma boa administração, não só deste município, mas como um todo da Grande São Paulo, o grande erro vem de uma, e sobra para os municípios pequenos".

Em seguida solicitou-se que dessem sugestões para melhorar os serviços de saúde do município. Poucos funcionários responderam a esta questão: "que todos falem a mesma linguagem"; "mais incentivo dos órgãos competentes"; "só precisa de mais funcionários"; "se houvesse interesse da prefeitura"; "é difícil, não resolveria".

\subsubsection{Sobre os Recursos Humanos}

A outra questão foi sobre a opinião dos auxiliares de enfermagem sobre o número de funcionários da Unidade: "quadro pequeno de funcionários, grande procura do público, principalmente auxiliares de enfermagem, para o bom andamento do serviço e um desempenho melhor no atendimento"; "suficiente"; "pouquíssimo escriturário, todos acabam se 
estressando"; "falta funcionários em todas as áreas, tanto na parte administrativa como na enfermagem, sendo que sempre estamos ajudando em outros setores, tais como escriturários, pessoal de limpeza"; "o número de funcionários está diminuindo"; "aqui acredito que está faltando mais escriturários, auxiliares de enfermagem, pediatra, ginecologista, clínico para a parte da tarde"; "defasado por falta de profissionais da saúde".

Quanto à questão sobre reciclagem ou educação continuada oferecida aos auxiliares de enfermagem: sete dizem que gostariam de fazer; enquanto que seis referem que não são oferecidos; "sempre precisamos renovar nossos conhecimentos, por enquanto espero que nos convide para aumentar nossos conhecimentos e faz parte de nossa profissão e crescimento cultural"; "desde que estou nesta Unidade não houve nenhum. E estamos precisando"; "tem vários cursos"; "já há algum tempo que não acontece uma reciclagem, e tem funcionários que estão precisando ser treinados"; "na minha opinião, se pudéssemos participar de cursos e atualizações profissionais, seria bom".

Foi solicitado também que relatassem os principais problemas de recursos humanos que enfrentam: "contratação de mais funcionários na área técnica e na área administrativa"; "falta de funcionários"; "algumas especialidades médicas e auxiliares de enfermagem"; "mais recepcionistas e computadores"; "uma assistente social para encaminhar os casos que 
houver necessidade, fazer palestras com usuários dar informações sobre doenças transmissiveis, infecto contagiosas e necessidades do usuário".

\subsubsection{Sobre o SUS}

Questionou-se o que os funcionários entendiam por Sistema Único de Saúde. Eles responderam: "órgão que administra o sistema"; "é a descentralização da saúde"; "um sistema que atende a todos sem discriminação"; "é um sistema único de saúde dirigido pelo governo do Estado"; "o que comanda os municípios"; "deveria ser um entrosamento melhor entre Estado, prefeitura e governo federal, para melhor atendimento aos pacientes"; "integração entre municipio e estado na prestação de atendimento à população".

Poucos auxiliares de enfermagem responderam à questão sobre as mudanças sentidas no serviço após a implantação do Sistema Único de Saúde: três responderam que não observaram mudanças; outros dizem que: "sim, para pior"; "ponto de referência"; "Houve, radicalmente, pois não tivemos material para uso de hospitais e postos de saúde com abundância como era antigamente quando o governo federal tomava conta desta parte"; "não eu acho que se o posto atende toda população, só pode ser pelo SUS, porque a classe pobre não tivesse o SUS iria ficar pior"; "maior facilidade principalmente nos exames mais complexos". 
Sobre os pontos positivos após a implantação do Sistema Único de Saúde: três disseram que não houve nenhum; "aumentou o número de especialidades médicas e laboratórios"; "atende a todos os exames solicitados, internações e medicação"; "não temos pontos positivos, pois a partir do momento que a verba diminui tudo é limitado, então quem acarreta os problemas são os pequenos usuários que dependem de todo o funcionamento do SUS desde cirurgias, locomoção de ambulâncias, medicações para doenças específicas muitas vezes acontece até chegar ao óbito por negligência"; "acabou com o acúmulo de usuários nas unidades centrais"; "Se alguém de um município, cidade, precisar usar o SUS, ele é atendido"; "abrangência maior no atendimento hospitalar e ambulatorial"; "todos são atendidos na medida do possivel".

Quanto aos pontos negativos após a implantação do Sistema Único de Saúde: duas referem que não houve nenhum; "estamos sempre nos esbarrando na burocracia"; "falta de medicação e condições de trabalho e muita burocracia"; "por exemplo, repasse de verba, que o Estado passa para a Prefeitura, para compra de medicação"; "falta de recursos humanos, má remuneração dos funcionários, falta de recursos materiais no atendimento"; "muitas ocasiões pelo funcionário não ter material adequado, por ganhar salários baixos sem o devido respeito como profissional, precisa trabalhar até em 3 empregos". 


\subsubsection{Sobre a UBS}

Sobre a existência da divulgação dos serviços prestados pelas Unidades e a forma como é feita: 10 responderam que sim; "pelos próprios pacientes"; "nas campanhas de vacina e na coleta de papanicolaou"; "com folhetos, cartazes e faixas"; "nos jornais da região e a própria população que passa de uma pessoa para outra"; "nos programas de saúde"; "aos poucos os próprios usuários saem divulgando os bons serviços recebidos da Unidade"; "você procura valorizar os seu trabalho servindo bem a população".

Solicitou-se que opinassem sobre o espaço físico da unidade em que trabalham; "estou satisfeita com o espaço"; "no momento está pequeno, pois a procura no atendimento é grande"; "poderia ser maior para servir melhor"; "muito bom só falta manutenção"; "pequeno"; "bom no tamanho certo"; "eu acho horrivel".

Sobre os equipamentos da UBS: "bom, mas poderia melhorar um pouco"; "péssima qualidade, não há manutenção adequada"; "temos o colposcópio, estufa, oxigênio em cilindros. Se tivermos mais em número e mais modernos, melhor"; "muito antigos e velhos"; "tudo precisando de reparos, ou seja, de equipamentos novos"; "como esta unidade foi inaugurada há pouco tempo, faltam ainda alguns pormenores". 
Quanto à opinião dos funcionários sobre os recursos técnicos: "são todos maravilhosos, mesmo sendo poucos"; "pouco, poderia ser melhor. O mais importante é aumentar o quadro de funcionários e oferecer reciclagem urgente aos mesmos"; "bom, mas se pudermos ter mais poderíamos aumentar o número de atendimento para a população"; "até que não tenho reclamações"; "espero que com o passar do tempo melhore o espaço, aumente os funcionários para poder ajudar mais a população, não depende só do secretário da saúde e o prefeito da cidade, mas sim de um todo incluindo toda a população". 
4.5 Identificação dos Auxiliares de Enfermagem de Taboão da Serra

Este município conta com um total de 86 auxiliares de enfermagem, sendo que, apenas 33 retornaram os questionários, e destes, 31 são do sexo feminino e 2 do sexo masculino.

A idade variou entre:
26 anos a 36 anos - 8
37 anos a 47 anos - 10
48 anos e mais - 8
Os demais não preencheram o campo idade.

O tempo de contratação nos serviços de saúde do município, variou entre:

Até 1 ano: 4

De 2 a 5 anos: 15

De 6 a 10 anos: 9

Mais de 11 anos: 3 


\subsubsection{Trabalho na UBS}

\section{Tabela 23 - Atividades Básicas Desenvolvidas pelos Auxiliares de}

\section{Enfermagem de Taboão da Serra, 1998}

\begin{tabular}{|l|}
\hline Esterilização \\
\hline Farmácia \\
\hline Preenchimento de Planilha de Agendamento \\
\hline Preenchimento de Planilha de Morbidade \\
\hline Controle de Agendamento de Consulta Médica \\
\hline Vacinação \\
\hline Coleta de Material para Exames Laboratoriais \\
\hline Orientações para Pacientes \\
\hline Auxiliar de Consultório \\
\hline Arrumação dos Consultórios \\
\hline Coleta de Papanicolaou \\
\hline Mapa de Consolidação de Dados SIASUS \\
\hline Recepção \\
\hline Controle do Agendamento de Coleta de Exames Laboratoriais \\
\hline Medicações \\
\hline Curativos \\
\hline Sinais Vitais \\
\hline Inalações \\
\hline Grupos: Papanicolaou, Planejamento Familiar, Gestantes \\
\hline Coleta de PKU (exame do pézinho) \\
\hline Pré e Pós Consulta \\
\hline Eletrocardiograma - ECG \\
\hline Vigilância Epidemiológica \\
\hline Recebimento e Distribuição de Exames \\
\hline Retirada de Pontos \\
\hline Aplicação de Vacina BCG \\
\hline Sala de Fisioterapia \\
\hline
\end{tabular}


Solicitou-se aos funcionários que opinassem sobre o seu ambiente de trabalho, e uma das questões foi se eles gostam de trabalhar nesta Unidade; "não só nesta unidade, mas em qualquer outra, quando diz respeito à saúde do ser humano, porque gosto de fazer"; "ambiente tranqüilo, quase sempre muito bom, amizades e chefia são boas e o entrosamento com colegas e pacientes"; "porque sou útil"; "gosto das colegas que trabalham comigo"; "me adaptei com a Unidade e por ser perto de minha residência"; "porque trabalhamos em conjunto"; "porque somos uma equipe que trabalha em prol do usuário e temos uma chefia ótima"; "há 13 anos com as mesmas colegas e me dou muito bem com a população"; "mais ou menos, acho a organização deficiente, isto é, pouco funcional"; "sim, embora tenha que enfrentar muitas dificuldades com relação ao ambiente, falta de material, falta de condições, gosto do que eu faço"; "o trabalho não é rotineiro".

Sobre os fatores que facilitam o trabalho na Unidade: "segurança, confiança e apoio da direção, ter uma boa chefia"; "companheirismo, auto confiança e compreensão por parte da chefia"; "a aceitação da direção do posto quando sugiro mudanças"; "coleguismo entre os funcionários, união, colaboração"; "quando não falta vacina e material"; "não faltar material, médicos e medicamentos. Um bom ambiente de trabalho e a compreensão dos colegas da equipe"; "colaboração dos colegas do horário, como são dois períodos, um procurar ajudar o outro e não 'puxar o tapete' do colega"; por outro lado, outras dizem que "nada facilita"; "comunicação fácil com 
profissionais e chefia interessada e presente"; "quando o paciente traz o seu cartão de atendimento, cumpre horários e datas marcadas e quando as prescrições dos médicos são legiveis"; "meu trabalho sempre depende de outros antes, desde que ele tenha sido correto facilita o meu"; "o fato de trabalhar próximo à residência e o conhecimento de grande parte dos usuários"; "experiência profissional e trabalho em equipe".

Sobre os fatores que dificultam o trabalho: 22 referem "a falta de material"; "falta de limpeza"; "falta de padronização entre todos da Unidade"; "nenhum"; "falta de colaboração da equipe"; alguns se queixam da "falta de coleguismo, compreensão e de organização"; "falta de espaço físico"; "falta de medicamentos"; "a indisponibilidade das colegas em mudar vícios"; "falta de informatização"; "falta de funcionários" (sobrecarga de serviço devido ao número de funcionários); "falta de integração na equipe de enfermagem"; "os pacientes cumprir horário em dia de coleta de material para laboratório"; "falta de experiência profissional"; "falta de controle do arquivo".

Em seguida solicitou-se sugestões para melhorar o serviço: "mais mão de obra e mais serviços especializados"; "rodizio de atividades e treinamentos. Priorizar a ética profissional com os funcionários desta Unidade. Respeito. Postura dos colegas diante dos pacientes"; "treinamento adequado para todos os funcionários"; "as autoridades, chefias diretas e indiretas, valorizar mais o profissional de saúde, investindo mais nele em todos os sentidos, equipar melhor as unidades, pois estamos trabalhando 
praticamente com os equipamentos todos em péssimas condições"; sugerem que tenha "mais espaço físico para melhor atender à população"; "acho que teríamos condições de melhorar muito os serviços na nossa unidade se não tivesse tanta gente que não é do nosso município"; "não faltar material, medicamentos e fazer reciclagem"; "melhor entendimento sobre as rotinas e material para que se possa melhorar o trabalho"; "melhoria de salário para não ter dois empregos e servir melhor no local de trabalho"; "mais funcionários"; "mais medicamentos e médicos especializados"; "reuniões periódicas"; "melhor divulgação dos serviços prestados pela Unidade, e como fazer uso das mesmas"; "organizar melhor o arquivo e que as pessoas que manuseiam os prontuários tenham mais cuidado com eles. Trocar os prontuários já velhos por novos, pois a cada manuseio um pedaço vai embora"; "um pouco mais de calor humano, paciência e boa vontade".

\subsubsection{Sobre os Recursos Humanos}

Solicitou-se aos auxiliares de enfermagem, que opinasse sobre a quantidade de funcionários da UBS onde trabalham, alguns dizem que está "bom, conseguimos trabalhar em equipe para o bom andamento da Unidade"; "tem funcionários suficientes para desenvolver bem o trabalho, falta somente médicos"; "o número de funcionários está compativel com o 
atendimento, se todos trabalharem visando o mesmo objetivo"; "bom, se cada um fizer seu serviço, tudo correrá bem".

No entanto a maioria considera que está "defasado - salários baixos"; "o número diminuiu, são poucos funcionários para prestar serviço"; "regular, porém, tarefas mal distribuídas, por falta de funcionários"; "muito pouco, há anos estamos trabalhando com o minimo de pessoal, é impossivel desempenhar trabalho bem feito com este número de pessoal"; "não há escriturários na Unidade, as auxiliares de enfermagem assumem esse papel, não havendo portanto, como desenvolver atividades inerentes ao cargo"; "são poucos, por isto os usuários nos agridem com palavras, por não ser atendidos e ter que esperar; há acúmulo de serviço/desvio de função"; "alguns dias o número é pouco, como em dias de coleta de material"; "poucos, porque quando sai de férias ou de licença sobrecarrega os que ficam e tumultua a Unidade; e devido às especialidades, sobrecarrega os funcionários e dificulta o atendimento"; "o quadro de funcionários está incompleto"; "insuficiente. Precisamos de mais profissionais desde médicos, auxiliares de enfermagem, pessoal de limpeza; a população usuária é grande".

Foi perguntado sobre o oferecimento de reciclagem ou educação continuada: 14 responderam que não é oferecido; "já houve reuniões mas nada oficial"; "isso faz muita falta a todos os auxiliares"; "para alguns, não são para todos. Às vezes alguns são convocados para alguns cursinhos". 
Outros responderam que sim, mas não mencionaram o tipo; "são poucas, deveria ter mais".

Sobre os principais problemas de recursos humanos: "treinamento de vez em quando, ética, respeito, postura e responsabilidade"; "faltam treinamentos e cursos de aperfeiçoamento"; "divisão de tarefas, maior número de profissionais para cada setor, não tendo assim que desviar os auxiliares para outras funções"; "não há escriturários e os funcionários estão mal distribuidos (pelo menos no meu horário)"; "falta de médicos principalmente ginecologista no terceiro período"; "falta assistente social"; "atenção igual para todos"; "problemas pessoais de alguns funcionários que deixam a Unidade desfalcada"; "condução (vale transporte) e comunicação (com a secretária de saúde)"; "falta de reciclagem"; "falta de um profissional específico na área"; "falta de informações sobre atendimento"; "falta de pessoal".

\subsubsection{Sobre o SUS}

Solicitou-se que respondessem o que entendem por Sistema Único de Saúde e, as respostas obtidas foram as seguintes: "que é um só", a maioria deles não respondeu a esta questão; "sei que significa Sistema Único de Saúde, e que através dele são conveniados alguns hospitais e exames, que são referências da nossa Unidade"; "é um sistema criado para 
atender melhor a população"; "todo cidadão tem direito à saúde"; "dar atendimento a todo cidadão independente de qualquer contribuição"; "Sistema Único de Saúde, que na prática teria que funcionar como o título, mas não funciona, deixa muito a desejar"; "um Sistema que facilita a população por ser unificado"; "um Sistema muito falho de atendimento à população"; "Sistema que abrange a saúde do Brasil"

Foi questionado quanto a mudanças sentidas após a implantação do Sistema Único de Saúde. As opiniões obtidas foram: "houve, para piorar a vida do pobre"; "no geral não notei grandes diferenças, pois sempre temos dificuldades, na obtenção de vagas e exames"; "sim, vários lugares não recebem muitos pacientes por falta de pagamento do SUS"; "houve, onde a pessoa for é atendida, principalmente se tiver encaminhamento"; alguns disseram que sim "aumentou a burocracia"; "para nós não sei, acho que poucas, pois os municipios têm o seu próprio sistema de saúde"; "houve, porém, não muito significativo"; "houve, os funcionários do SUS aproveitam muito dos funcionários da prefeitura"; parte dos funcionários não respondeu; "não conhecia o Sistema anterior"; "sim, em relação ao atendimento"; "sim, não havia remédios para doenças graves, como programa de alto custo".

A questão seguinte foi sobre os pontos positivos que eles notaram após a implantação do Sistema Único de Saúde: 11 não responderam a pergunta e 13 não souberam referir nada. Outros deram opiniões tais como: "campanha de vacinação lançada pelo Governo, campanha de alerta a 
doenças infecto-contagiosas"; "melhor atendimento ao público"; "seria muito bom se a administração fosse mais elaborada, mas infelizmente, a saúde deixa muito a desejar, principalmente o SUS"; "aumento do número de leitos em hospitais e reforma em geral. Exame de tomografia gratuito"; "melhor atendimento ao paciente, mas pode melhorar mais"; "implantação do programa de alto custo, programa de controle de natalidade, com maior orientação sobre métodos, saúde da mulher, assistência odontológica à criança e gestantes, implantação de especialidades no município, inclusive neurologia".

A outra questão abordada foram os pontos negativos após a implantação do Sistema Único de Saúde: 23 auxiliares de enfermagem não responderam esta pergunta, os demais opinaram: "falta de vagas para internação em hospitais para atendimento de fraturas e traumatismos"; "mal administrado"; "demora nos resultados dos exames"; "falta de vagas tanto em hospitais como para alguns exames laboratoriais"; "muita lotação de pacientes em Unidades precárias"; "redução na distribuição de medicamentos, burocracia continua: demora no atendimento devido a grande demanda"; "acho que no meu município as verbas destinadas à saúde deveriam ser mais bem empregadas, assim como em outros municipios"; "dificuldade nos atendimentos, falta de medicamento, falta de vagas nos hospitais e especialidades"; "falta de verba". 


\subsubsection{Sobre a UBS}

Sobre a divulgação dos serviços prestados pelas unidades e o meio utilizado para esta ação: cinco deixaram de responder esta questão e alguns responderam que não; "como já foi citado anteriormente, esta grande falta de informações denigre a imagem do serviço prestado pelo município". A maioria considera que sim, "nas campanhas de vacinação, na sala de vacinas, na coleta de papanicolaou, nos grupos de planejamento familiar, hipertensos e em reuniões com gestantes"; "a diretoria junto com funcionários, estão sempre em busca de pacientes com doenças"; "existe a divulgação boca a boca dos próprios pacientes atendidos e os meios de comunicações"; "através de cartazes"; "orientações da enfermagem para a comunidade, através de visitas domiciliárias"; " de UBS para UBS, pela secretaria da saúde, e os próprios pacientes, na maioria das vezes pelos próprios funcionários".

Questionamos se há encaminhamento de pacientes para outros serviços, todos deram resposta afirmativa.

Os serviços para os quais os pacientes são encaminhados são: Pronto Socorro, Unidades Básicas de Saúde que possuem especialidades; "quando há a necessidade de tratamentos inexistentes em nossa unidade, tais como: cirurgias em geral, mamografia, $R X$, oftalmologia, neurologia, vascular, otorrinolaringologia, gastroenterologia, dermatologia, urologia, 
ultrassonografia, cardiologia, ortopedia, exames laboratoriais, partos, internações"; "serviços de urgência e emergência e assistência social"; "Hospital das Clínicas, Oncocentro, Hospital da Mulher, Hospital Regional Pirajussara e UBS Jardim Helena e PA Santo Onofre".

Solicitou-se que opinassem sobre o espaço físico da unidade: "espaço muito bom porém, pouco ventilado"; "amplo"; "a Unidade tem um espaço físico suficiente ao que se propõe"; "bom, mas falta mais salas"; "por ora está adequado, se aumentar o atendimento e vier mais especialidades vai ficar pequeno"; "falta espaço físico"; "de maneira geral, muito pequena"; "salas mal arejadas, consultórios com sol na parede e sem ventilação"; "não tem"; "pequeno, poucos consultórios, salas pequenas e muito quentes"; "deu uma melhorada mas acho que deveria ter mais salas"; "péssimo, estão providenciando uma Unidade nova"; "acho que é suficiente para o que atendemos"; "precário"; "pequeno"; "ruim"; "falta sala para coleta de sangue"; "salas pequenas e poucos banheiros"; "ridiculo, 100 metros quadrados"; "razoável"; "falta sala para desenvolver todas as atividades desta unidade"; "refeitório para os funcionários do posto e vestiário".

Sobre os equipamentos da UBS: "de ótima qualidade"; "bom"; "na medida do possivel tem o que precisa"; "quase todos em bom funcionamento"; "bom, porém com falta de vários"; "suficiente"; "razoável"; "são poucos, porém úteis"; "ruins, principalmente da sala de esterilização"; "só temos o básico"; "regular"; "poderia ter mais equipamentos"; "péssimos, 
estão mal conservados, quebrados e ultrapassados"; "são um pouco antigos, mas acredito que mudará em breve"; "precários"; "falta manutenção dos equipamentos"; "ultrapassados. Não tem um foco adequado na sala de GO. Aparelhos de pressão (precários), faltam aparelhos para laringoscopia"; "funcionam regularmente".

Sobre os recursos técnicos da Unidade: a maioria dos funcionários não respondeu esta questão. Alguns opinaram dizendo que "acredito que há recursos técnicos suficientes às nossas necessidades"; "bom"; "suficiente"; "ótimos", outros consideram que estes recursos são: "inexistentes"; "precários"; "na minha concepção é o mínimo necessário"; "são poucos". 


\section{DISCUSSÃO}

As informações obtidas através dos questionários distribuídos nas diversas UBS dos municípios em estudo levaram às considerações a seguir descritas.

A grande dificuldade encontrada foi que os dados obtidos muitas vezes apresentaram, ora visões consensuais, ora contraditórias na mesma realidade, o que fez com que se descrevesse todas as respostas obtidas, para um melhor entendimento.

$\mathrm{Na}$ tabulação dos dados, as questões foram categorizadas e classificadas conforme as variáveis abordadas nos questionários, inicialmente com a identificação do pessoal, noções do Sistema Único de Saúde, recursos humanos, Unidade Básica de Saúde.

Os municípios estão engajados no processo da política de saúde do país, estando, ambos, habilitados, porém em gestões distintas.

O município de Ferraz de Vasconcelos, obedecendo a NOB/96, está habilitado na Gestão Plena da Atenção Básica, pela Portaria MS no 4, de 5 de janeiro de 1999, publicada no D.O.U. de 6/1/99, e Taboão da Serra 
habilitado na Gestão Plena do Sistema Municipal, pela Portaria MS no 2.553, de 4 de maio de 1998, publicada no D.O.U de 26/5/98.

Apesar dos municípios possuirem populações semelhantes e estarem contemplados com o mesmo número de equipamentos na rede física, a quantidade de pessoal de enfermagem difere muito. No municipio de Ferraz de Vasconcelos encontramos um total de seis enfermeiros e 29 auxiliares de enfermagem e em Taboão da Serra, 17 enfermeiros e 89 auxiliares de enfermagem. A participação neste processo de estudo da força de trabalho em enfermagem, em ambos os municípios, foi parcial, notou-se que há pouca vivência deste pessoal em processos semelhantes.

Ainda quanto à quantificação do pessoal de enfermagem, tanto no município de Ferraz de Vasconcelos, quanto em Taboão da Serra, os enfermeiros consideram o número insuficiente, apesar do segundo municipio possuir um contingente maior. É verdade, porém, que a sua população é superior em quantidade.

Após a implantação do Sistema Único de Saúde houve algumas mudanças em relação aos recursos humanos específicos na área da enfermagem, principalmente porque houve remanejamento de pessoal, e em algumas unidades diminuiu o quadro de funcionários e, com isto, ocorreram desvios de função. Isto se deve, provavelmente, ao aumento do número de 
estabelecimentos de saúde, o que demanda um aumento da produção, e da oferta de serviços, impostos pelo novo Sistema de Saúde.

Notou-se ainda que há remanescentes dos atendentes de enfermagem nos dois municipios. Comparativamente, Ferraz de Vasconcelos apresenta um percentual maior deste pessoal, o que faz deduzir que isto ocorre devido ao processo da política de saúde que interfere junto aos recursos humanos nesta área. Há também o interesse dos municípios em promover o desenvolvimento de recursos humanos, através de cursos de aprimoramento.

Enquanto o município de Taboão da Serra está habilitado na Gestão Plena do Sistema Municipal há mais de um ano, o que demanda uma série de compromissos e responsabilidades para a manutenção de sua Gestão, inclusive na questão de recursos humanos, Ferraz de Vasconcelos está habilitado na Gestão Plena de Atenção Básica há apenas alguns meses, este município ainda estava em fase inicial de desenvolvimento de sua gestão.

Segundo a Lei 8.080 de 1990 , é função do município a formação dos recursos humanos e seu desenvolvimento para exercer as atividades exigidas para suprir as necessidades de assistência à saúde da população. Neste sentido, com a diminuição do número de atendentes de enfermagem, observou-se que a chamada "bipolarização da força de trabalho do setor 
saúde", apontada pelo Grupo de Trabalho do Ministério da Saúde em 1989, hoje já não se configura mais, pois os atendentes de enfermagem estão em plena extinção, como prevê a Lei $n^{\circ} 7.498$, que regulamenta o exercício da enfermagem (1986).

No desenvolver do estudo notamos que esta tendência anteriormente citada, também não ocorre nos municípios da pesquisa. Em relação ao contingente de atendentes de enfermagem vem diminuindo significativamente.

Uma tendência observada é a participação crescente da mão de obra feminina. Nota-se, neste estudo, que no Município de Taboão da Serra, $98 \%$ do pessoal de enfermagem é composto pelo sexo feminino, e em Ferraz de Vasconcelos 94\%, confirmando o que MACHADO(1987) e o Grupo de Ministros(1989) ressaltaram em seus estudos.

Na área da formação de pessoal de enfermagem, a diferença entre os sexos feminino e o masculino certamente deve girar em torno de $95 \%$, de acordo com a nossa vivência prática.

Quanto ao "rejuvenescimento significativo da força de trabalho empregada" citada por MACHADO (1987), notamos que os enfermeiros de Ferraz de Vasconcelos, com até 29 anos representam $17 \%$ do total e entre 30 e 45 anos, $83 \%$. Em Taboão da Serra, encontrou-se apenas enfermeiros 
com idade variando entre 30 e 49 anos, o que demonstra que esta população, em ambos municípios a população de enfermeiros, vem envelhecendo. Estes resultados não.são animadores, visto que os jovens assimilam com maior rapidez as modificações que vêm sendo implantados no SUS.

Do mesmo modo nos auxiliares de enfermagem, verifica-se que a constatação de MACHADO (1987), não se observa no município estudado, um grupo desses funcionários apresenta idade variando de 30 a 40 anos, representando $37 \%$, outro de 41 a 50 anos, representando $50 \%$, e um grupo de $13 \%$ com mais de 50 anos, em Ferraz de Vasconcelos. Em Taboão da Serra encontramos $25 \%$ com idade variando de 20 a 30 anos, $20 \%$ com idade entre 31 e 40 anos, $20 \%$ com mais de 40 anos, $35 \%$ deixaram de responder esta pergunta.

Este fato, associado ao tempo de contratação que concentra maior número entre um e cinco anos de trabalho na área da saúde, demonstra que a população feminina está começando suas atividades mais tardiamente, o que faz supor que também o nível de escolaridade vem se incrementando, pois, assim como os atendentes de enfermagem vem freqüentando os cursos de auxiliares de enfermagem, por sua vez, procuram se aprimorar cursando a graduação em enfermagem. 
Alguns enfermeiros, de ambos os municipios, freqüentaram também para seu aprimoramento, cursos e especializações em algumas faculdades e universidades. Por outro lado, para seu desenvolvimento em nível local, são raros os cursos de reciclagem ou treinamentos oferecidos pelos municípios. QUADRA e AMÂNCIO (1978) ressaltam a importância da qualificação profissional e a atualização no processo de trabalho cotidiano, o que não ocorre desde os anos 60 Neste aspecto, BOGUS (1994), salienta a importância de existirem diretrizes na área de treinamento e desenvolvimento de pessoal para a sustentação à implantação do SUS, o que também não se observou nos municípios estudados.

Dentre as atividades desenvolvidas pelos enfermeiros, os de Ferraz de Vasconcelos estão restringidos aos cuidados assistenciais diretos, deixando as ações administrativas, em alguns aspectos, sem a atenção devida, principalmente quanto à supervisão da equipe de enfermagem e aos cuidados preventivos, com destaque para a área epidemiológica, conforme observa-se pelos dados levantados entre os enfermeiros do município.

Em Taboão da Serra, por sua vez, demonstram que estão mais organizados e cobrem, de um modo geral, tanto as atividades assistenciais quanto as administrativas, o que faz supor que isto se deve ao fato deste município contar com um quantitativo maior de enfermeiros e em vários turnos alem da política de saúde local. 
CASTELLANOS, SHIMA, BERTOLOZZI, EGRY (1989), consideram o processo de trabalho da enfermagem em dois momentos: o de "cuidar" e "administrar". O que se observou nos municípios, é que enquanto Ferraz de Vasconcelos se concentra na atenção individual, Taboão da Serra está atento ao processo individual e coletivo, como se apresentam.nos dados anteriormente citados.

Corroborando com o estudo realizado por VAZ (1989), os enfermeiros de Ferraz de Vasconcelos opinam por uma preferência pelas ações diretas à clientela. Já as enfermeiras de Taboão da Serra, apesar de dispensarem tempo para as atividades administrativas, algumas delas consideram estas funções "muito burocráticas".

Em ambos os municípios, os enfermeiros não referiram participação nas ações de política de saúde tanto da Unidade em que trabalham, como na Secretaria da Saúde. Ao mesmo tempo, observa-se que a direção das Unidades, assim como a Secretaria Municipal da Saúde, também não os envolvem no processo. A $1^{\text {a }}$ Conferência Estadual de Saúde (1991) destacou três aspectos da política de recursos humanos frente ao SUS: "os resultados do setor saúde dependem da relação entre o cliente/comunidade e a equipe de saúde; o investimento nos recursos humanos como melhoria da saúde da comunidade e os trabalhadores da saúde como agentes de mudança", o que não ocorre com o pessoal de enfermagem destes 
municipios, pois não participam como sujeitos do processo de reorganização do sistema de saúde.

Quanto às questões relativas às Unidades Básicas de Saúde, em ambos os municípios, as UBS estão localizadas em pontos estratégicos, próximos aos grandes bairros. As unidades estão, de um modo geral, em prédios próprios para este fim, e algumas foram construídas pela Secretaria de Estado da Saúde, com sedes de dois andares e bem amplas, que passaram para os municípios devido à municipalização da saúde.

Vale comentar que quanto à área de abrangência, as UBSs estão delimitadas pelos bairros onde se localizam, mas atendem um número maior do que se propõem, pois não tem sido possível rejeitar pacientes, e em algumas unidades, existem especialidades médicas que servem de referência para até outros municípios.

Os equipamentos que servem os serviços de saúde estão, de um modo geral, adequados e, segundo alguns enfermeiros, sua manutenção é deficitária ou nula.

O que tem faltado, nos municípios, são material de consumo e medicamentos, e um dos entraves para o bom desenvolvimento do trabalho da enfermagem tem sido, principalmente no município de Ferraz de Vasconcelos, a falta de profissionais enfermeiros. 
Em relação ao sistema de informação, ainda está precário, os municípios não estão informatizados em rede nas unidades de saúde. Em Taboão da Serra existe uma rotina de reuniões mensais com o pessoal das UBSs e um sistema de troca de informações "via malote" feito por um motorista da Secretaria da Saúde em dias alternados, além do ramal telefônico em casos mais urgentes.

As enfermeiras de Taboão da Serra fazem programas educativos com a população nas unidades, promovendo reuniões para grupos com interesses específicos, tais como: gestantes, hipertensos, adolescentes, hansenianos, planejamento familiar e coleta de papanicolaou. Como na região do Córrego Pirajussara em Taboão da Serra ocorrem enchentes em tempos de chuvas intensas, elas fazem orientações sobre os problemas de saúde que podem ser ocasionados nestes periodos.

Em Ferraz de Vasconcelos também há atividades educativas, através de grupos de orientações para planejamento familiar, aleitamento materno, diabetes e hipertensão, comparativamente em proporções menores que Taboão da Serra, pode-se dizer que isto é devido ao quantitativo de enfermeiros e ao planejamento e organizaçăo do serviço de enfermagem de cada município. 
Quanto aos auxiliares de enfermagem, as atividades desenvolvidas são basicamente as mesmas nos dois municípios.

A maior parte referiu gostar do ambiente de trabalho, consideram bons os colegas de trabalho, entretanto, é o fato de residirem próximos à UBS o que mais agrada e, com isto, facilita tanto o acesso quanto o fato de conhecerem os usuários das Unidades.

Sobre o trabalho na UBS, da chefia e da direção das unidades, o que mais traz satisfação para o pessoal de enfermagem, é a compreensão e o reconhecimento do seu trabalho. Dos colegas, a colaboração e o fato de poder ser útil para a população, da qual muitos fazem parte.

Quanto aos fatores que dificultam o trabalho, a principal queixa é a falta de material de consumo e de funcionários, o que os leva a uma sobrecarga de tarefas.

Segundo opiniões sobre a questão da satisfação no trabalho, um dos fatores que evidencia o baixo quantitativo de funcionários, em Ferraz de Vasconcelos, é o baixo salário. Outro problema identificado é a falta de profissionais, além do enfermeiro, os auxiliares de enfermagem sentem falta de mais médicos, em ambos os municípios. Além destes, outros trabalhadores, tais como: pessoal de limpeza e escriturários, porque muitas vezes os auxiliares de enfermagem são obrigados a substitui-los, e com 
isto, deixam de oferecer alguns serviços especificos da enfermagem, com melhor qualidade.

Solicitou-se que dessem sugestões, para a melhoria da qualidade dos serviços oferecidos na Unidade, porem, na maioria das vezes os funcionários, vincularam as respostas das questões aos recursos humanos e materiais.

Quanto à questão sobre reciclagem e educação continuada, em nenhum dos dois municipios existe este processo de rotina. Os auxiliares de enfermagem se sentem defasados pela falta deste processo.

No que se refere ao Sistema de Saúde, os funcionários não estão acompanhando e nem estão participando de sua evolução. Quando questionamos a respeito do Sistema Único de Saúde, os auxiliares de enfermagem do município de Ferraz de Vasconcelos, apesar de menor tempo habilitados, parecem mais esclarecidos quanto ao processo e como ele funciona. Os funcionários de Taboão da Serra, em sua maioria, deixaram de responder a esta questão.

Quando perguntados sobre mudanças sentidas no sistema de saúde do municipio após a implantação do SUS, em sua maioria, em ambos os municípios, os participantes não responderam ou manifestaram-se através de pareceres pessimistas. 
Abordou-se sobre a divulgação dos serviços oferecidos pela UBS; ela é feita pelos funcionários e pela população "boca a boca", quando os usuários, são bem atendidos nas Unidades. Além disso, também há divulgação nas reuniões em grupo e nas campanhas, onde se tem a oportunidade de atingir grande número de pessoas.

Os encaminhamentos de pacientes acontecem quando o serviço não possui especialidades. Nestes casos, são enviados às unidades mais próximas ou para laboratórios clínicos para exames especificos ou ainda, para os hospitais de referência, caso seja necessário.

O espaço físico das UBS, de um modo geral, é bom em Taboão da Serra, apenas um referiu como pequeno, e que os funcionários não gostam de sua localização, devido ao barulho que a escola que se situa ao lado proporciona, além de ser pouco iluminado e ventilado.

Já em Ferraz de Vasconcelos, apesar das unidades serem novas, os funcionários não estão satisfeitos, pois as construções não facilitam o fluxo de pacientes e não oferecem conforto para os funcionários e usuários.

Os equipamentos utilizados nas UBS em ambos os municípios necessitam de manutenção constante por estarem antigos, como salientaram os enfermeiros. 
Quanto aos recursos técnicos das unidades, apesar de poucos responderem a esta questão, a maioria consideram bons, porém insuficientes.

Observou-se então que, nos municípios de Ferraz de Vasconcelos e Taboão da Serra, os principais problemas referentes aos recursos humanos, detectados pelo Grupo de Trabalho nomeado pelo Ministro da Saúde em 1989, ainda persistem na área de recursos humanos em enfermagem. 


\section{CONSIDERAÇÕES FINAIS}

Através do presente estudo, foi possivel verificar que os municipios de Ferraz de Vasconcelos e Taboão da Serra estão em pleno processo de desenvolvimento do Sistema Único de Saúde, habilitados na Gestão Plena da Atenção Básica e Gestão Plena do Sistema Municipal, respectivamente. Os seus agentes de saúde, em especial, o pessoal de enfermagem, ainda estão por iniciar a sua participação neste processo. Estas transformações no processo político e na sociedade devem ser acompanhadas por todos os atores sociais, para que haja a compreensão das mudanças que vêm ocorrendo em âmbito global e não somente na área da saúde.

O que se pode observar é que a equipe de enfermagem está voltada para seu cotidiano, por vezes, não estando consciente do seu valor como agente de mudança na melhoria da qualidade da saúde de um município.

O novo modelo de atenção à saúde, integrado à proposta do Sistema Único de Saúde, normatizada pelo NOB/SUS-96, com a finalidade de consolidar o exercício do poder público municipal em relação à atenção a saúde dos seus munícipes, fornece os requisitos para favorecer o direcionamento de sua ação. 
Desta forma, este novo modelo de atenção à saúde amplia o atual vigente, que está centrado na doença, incorporando o modelo epidemiológico que atende a integralidade da atenção, principalmente no município de Ferraz de Vasconcelos, envolvendo a relação da equipe de saúde com a comunidade.

Observou-se a composição da força de trabalho da enfermagem, com as categorias que os municípios contam, sendo apenas de enfermeiros e auxiliares de enfermagem. Alguns remanescentes de atendentes de enfermagem ainda se fazem presentes, principalmente em Ferraz de Vasconcelos. Considera-se positiva esta composição, principalmente na proposta da política atual da enfermagem, objeto de estudo deste trabalho.

Nos municípios estudados, alguns atendentes de enfermagem estão em processo de formação nos cursos de auxiliar de enfermagem que vem sendo oferecido ininterruptamente.

As normas operacionais do Sistema Único de Saúde, incentivam a implantação do Programa de Saúde da Família, com equipes de saúde da família de médicos, auxiliares de enfermagem e os agentes comunitários de saúde, o elo da comunidade com a rede municipal de saúde. Este Programa, no entanto, ainda não está implantado em ambos municípios. 
No tocante à quantificação de pessoal de enfermagem, fica evidente a diferença numérica dos enfermeiros e auxiliares de enfermagem nos municipios. Taboão da Serra, por possuir uma população maior, o contingente é três vezes maior que Ferraz de Vasconcelos, apesar disso, em ambos municipios os participantes da pesquisa opinam que o número de pessoal é insuficiente.

Frente a esta constatação, o quantitativo e qualitativo das ações desempenhadas, principalmente pelos enfermeiros, são bastante diversificados em Taboão da Serra, enquanto que em Ferraz de Vasconcelos muitas destas ações deixam de ser executadas.

Outros aspectos constatados junto ao pessoal de enfermagem são a grande participação da mão de obra feminina e o incremento na escolaridade e aprimoramento da equipe através de cursos e especializações realizados pelos enfermeiros, em ambos municípios.

Os enfermeiros em geral opinam que, dentre as suas funções, a preferência é pelas atividades assistenciais diretas aos clientes, em detrimento das ações administrativas. Entre os auxiliares de enfermagem, não se distinguiram diferenças marcantes nas ações, e em suas atribuições nos municipios, apesar de estarem em gestões distintas. 
Devido à tendência dos enfermeiros em termos de suas funções, de ambos os municipios, estarem mais voltadas para as ações assistenciais, e pela falta de funcionários de outros setores, tais como: escriturários e pessoal de limpeza, nota-se que os auxiliares de enfermagem sentem dificuldades no desenvolvimento do trabalho, organizado e supervisionado, que lhes é pertinente, e muitas vezes com desvio de função de ambas as partes.

Observou-se no estudo, que a composição e a quantidade da equipe de enfermagem, é fundamental para o desempenho adequado das ações de enfermagem de saúde pública. Apesar da maioria deles, estar satisfeita com o ambiente de trabalho e as respectivas atribuições que desempenha; no entanto, frente às mudanças que vêm ocorrendo nos municípios, a participação desses atores sociais é primordial neste processo político de saúde atual, para a prestação de uma assistência integral e de qualidade para a população. 


\section{REFERÊNCIA BIBLIOGRÁFICA}

Almeida MCP. O trabalho de enfermagem e sua articulação com o processo de trabalho em saúde coletiva: rede básica de saúde em Ribeirão Preto. Ribeirão Preto; 1991. [Tese de Livre-Docência. Escola de enfermagem de Ribeirão Preto - USP].

Almeida MCP, Mishima SM, Silva EM, Mello DF. O trabalho da enfermagem e sua articulação com o processo de trabalho em saúde coletiva - rede básica de Ribeirão Preto. Rev. Bras. Enf.1991; 44(2/3):64-75.

Almeida MCP, Rocha SMM. (org) O trabalho de enfermagem. São Paulo: Cortez; 1997

Almeida MJ. As leis orgânicas municipais e a saúde. Saúde em Debate 1989; (24):26-7.

Andrade OB, Adami NP. Configurações das funções da enfermeira de saúde pública: modelo programático de preparo requerido para o exercício dessas funções. Enf. Novas Dimens. 1976; 2(6): 308-18.

Bógus $\mathrm{CM}$. Percepção dos trabalhadores de saúde quanto às mudanças ocorridas nos serviços a partir da implantação do SUS: a prática na teoria. Saúde e Sociedade 1994; 3(1):29-40. 
Brasil. Ministério da Saúde. Conferência Nacional de Saúde. $3^{a}$. Anais. Brasília: Ministério da Saúde; 1963.

Brasil. Ministério da Saúde. Anais da $7^{a}$ Conferência Nacional de Saúde. Brasilia; 1980.

Brasil. Ministério da Previdência e Assistência Social. Ministério da Saúde, Ministério da Educação e Cultura. Ações Integradas de Saúde. Brasilia (DF): Ministério da Saúde; 1984.

Brasil. Conselho Federal de Enfermagem. Lei $n^{\circ} 7.498$, de 25 de junho de 1986. Estabelece a lei do exercício profissional da enfermagem. Diário Oficial República Federativa do Brasil, Brasilia, 26 jun. 1986. p. 9.273 a 9.275 .

Brasil. Ministério da Saúde. Conferência Nacional de Saúde. $8^{a}$. Anais Brasilia: Ministério da Saúde; 1986.

Brasil. Constituição da República Federativa do Brasil. Brasilia: Senado Federal; 1988.

Brasil. Ministério da Saúde. Sistema Único de Saúde: diretrizes para formulação de política de recursos humanos. Brasilia; 1989.

Brasil. Lei n.8.080, de 19 de setembro de 1990. Dispõe sobre as condições para a promoção, proteção e recuperação da saúde, a organização e funcionamento dos serviços correspondentes e dá outras providências. 
Diário Oficial da República Federativa do Brasil, Brasilia, 20/9/90. Seção I. p. $18055-18059$.

Brasil. Lei n.8.142, de 28 de dezembro de 1990. Dispõe sobre a participação da comunidade na gestão do Sistema Único de Saúde - SUS e sobre as transferências intragovernamentais de recursos financeiros na área da saúde e dá outras providências. Diário Oficial da República Federativa do Brasil, Brasília, 29 /12/90.

Brasil. Ministério da Saúde. Normas e diretrizes. Programa de_Agentes Comunitários de Saúde. Brasília: Ministério da Saúde; 1994.

Brasil. Ministério da Saúde. Norma Operacional Básica SUS 1/96, Diário Oficial da República Federativa do Brasil, Brasília, 6 nov. 1996.

Brasil. Portaria $n^{\circ} 1.886$, de 18 de dezembro de 1997: aprova as Normas e Diretrizes do Programa de Agentes Comunitários de Saúde e do Programa de Saúde da Família. Diário Oficial da República Federativa do Brasil, Brasília, 19 dez. 1997.

Brasil. Portaria $n^{\circ} 157$, de 19 de fevereiro de 1998: estabelece os critérios de distribuição e requisitos para a qualificação dos Municípios aos incentivos ao Programa de Agentes Comunitários de Saúde e ao Programa de Saúde da Família. Diário Oficial da República Federativa do Brasil, Brasília,20 fev. 1998.

Campos GWS. Um balanço do processo de municipalização dos serviços de saúde no Brasil. Saúde em Debate 1990; (28):24-7. 
Carvalho GI, Santos L. Sistema Único de Saúde. Comentários à Lei Orgânica da Saúde (Leis $8.080 / 90$ e 8.142/90). São Paulo: HUCITEC; 1992.

Castellanos BEP, Shima H, Bertolozzi MR, Egry, EY. Os desafios da enfermagem para os anos 90. In: Anais do Congresso Brasileiro de Enfermagem; 1989; Florianópolis, Brasil. Associação Brasileira de Enfermagem.

Chiavenato I. Introdução à teoria geral da administração. $3^{a}$ ed. São Paulo: Mc Graw Hill do Brasil; 1983.

Dallari SG. Municipalização dos serviços de saúde. São Paulo: Brasiliense; 1985.

Franco LRO. Avaliação da exiqüibilidade das atribuições do enfermeiro de saúde pública, a nível local na Secretaria de Saúde de São Paulo. São Paulo; 1987. [Tese de doutoramento - Faculdade de Saúde Pública da USP].

Girardi SN. O perfil do emprego em saúde no Brasil. Cad. Saúde Públ. 1986; 2(4):423-39.

Gonçalves EL. Administração de recursos humanos nas instituições de saúde. São Paulo: Pioneira, 1987. 
Heimann LS et al. O município e a saúde. São Paulo: Hucitec; 1992.

Horta WA. Contribuição para uma teoria de enfermagem. Rev. Bras. Enf. $1970 ; 23(3 / 6): 119-25$.

Leopardi MT. Método de assistência de enfermagem: análise da utilização do instrumento no processo de trabalho. Ribeirão Preto; 1991.[Tese de doutoramento - Escola de Enfermagem de Ribeirão Preto da Universidade de São Paulo].

Macedo CG. Política de recursos humanos en salud. Educ. Med. Salud $1986 ; 20(4): 415-23$.

Machado MH. A participação da mulher na força de trabalho em saúde no Brasil - 1970/1980. In: Textos de apoio: planejamento I recursos humanos em saúde. Rio de Janeiro: Esc. Nac. Saúde Publ./ABRASCO; 1987.

Machado MH. Profissões de saúde: uma abordagem sociológica. Rio de Janeiro: Editora Fio Cruz; 1995.

Medici AC, Paim ER. Estrutura e dinâmica da força de trabalho em enfermagem. In: Textos de apoio: planejamento I recursos humanos em saúde. Rio de Janeiro: Esc. Nac. Saúde PúbI./ABRASCO; 1987.

Medici AC. O emprego de enfermagem no Brasil dos anos 80: luz no fim do túnel? Saúde em Debate 1989; (24):65-8. 
Mendes Gonçalves RB. O processo de trabalho em saúde. São Paulo; Departamento de Medicina Preventiva da Faculdade de Medicina da USP; 1988. [mimeografado]

Mendes, E.V. Distrito sanitário - o processo social de mudança das práticas sanitárias do Sistema Único de Saúde. São Paulo: HUCITEC/ABRASCO; 1994.

Nogueira, RP. A força de trabalho em saúde. Rev. Adm. Públ.1983; 17(3):61-70.

Nogueira RP. Dinâmica do mercado de trabalho em saúde no Brasil: 197083. Brasília; Organização Panamericana de Saúde; 1986.[Monografias do GAP, 1]

Oliveira Júnior, M. Administração de recursos humanos: um obstáculo à municipalização dos serviços de saúde? Saúde em_Debate 1990; (28):41-6.

Oliveira LSS. A profissionalização dos trabalhadores de enfermagem nos serviços de saúde: uma experiência de construção do projeto larga escala na cidade de São Paulo. São Paulo; 1996. [Dissertação de mestrado - Faculdade de Saúde Pública da Universidade de São Paulo].Paim JS. A reforma sanitária e a municipalização. Saúde e Sociedade 1992; 1(2):29-47.

Paim JS. Recursos humanos em saúde no Brasil: problemas crônicos e desafios agudos. São Paulo: Faculdade de Saúde Pública/USP; 1994. (Série ADSaúde,2) 
Quadra AAF, Amâncio AA. A formação de recursos humanos. In: Guimarães $\mathrm{R}$, organizador. Saúde e Medicina no Brasil. Rio de Janeiro (RJ): Graal; 1978.

Redução da mortalidade infantil no nordeste. Folha de São Paulo 1997 jan; cad. $3: 2$.

ROCHA SMM. Puericultura e enfermagem. São Paulo: Cortez; 1987.

São Paulo (Estado) Conferência Estadual de Saúde. 1a. Anais, 1991; São Paulo.

Tanaka OY, et al. A municipalização dos serviços de saúde no Estado de São Paulo. Saúde em Debate 1991; (33):73-9.

Trevizan MA. A função administrativa da enfermeira de instituição hospitalar burocratizada. Ribeirão Preto, 1986. [Tese de doutorado Escola de Enfermagem da USP].

Vaz MRC. O trabalho da enfermeira na rede básica de serviços de saúde - análise de depoimento. Ribeirão Preto; 1989. [Dissertação de mestrado - Escola de Enfermagem de Ribeirão Preto da Universidade de São Paulo]. 
Verdi M. Com a palavra a enfermeira: concepções teóricas que fundamentam sua prática nos serviços da rede básica de saúde. Florianópolis; 1993. [Dissertação de mestrado - Centro de Ciência da Saúde da Universidade Federal de Santa Catarina].

Villa TCS. A enfermeira nos serviços de saúde pública do Estado de São Paulo (1967 - 1983). Ribeirão Preto; 1992. [Tese de doutorado - Escola de Enfermagem de Ribeirão Preto da Universidade de São Paulo].

Witt, A. Metodologia de pesquisa. São Paulo: Resenha Tributária; 1973. 


\section{BIBLIOGRAFIA CONSULTADA}

Aragão RM. Recursos humanos para as atividades de saúde. Cad. RH Saúde 1993; 1(1):25-30.

Associação Brasileira De Pós-Graduação Em Saúde Coletiva (ABRASCO). A experiência SUDS e os desafios atuais da Reforma Sanitária. São Paulo, 1989.

Barros SMPF. Recursos humanos de saúde: um desafio estratégico para a qualidade da assistência de saúde e para a organização do SUS - com ênfase na enfermagem. Rev. Bras. Enf. 1991; 44(1):7-9.

Borba VR. Municipalização da saúde: roteiro básico e plano diretor. São Paulo: CEDAS; 1993.

Brasil. Conselho Federal de Enfermagem. O exercício da enfermagem nas instituições de saúde do Brasil: 1982/1983. Rio de Janeiro: Federal de Enfermagem/Associação Brasileira de Enfermagem; 1985.

Brasil. Ministério da Saúde. Modelos assistenciais no Sistema Único de Saúde: concepções e fundamentos, diretrizes e estratégias de implementação. Brasília; 1990. 
Brasil. Ministério da Saúde. A investigação sobre recursos humanos em saúde: relatório de seminário. Brasilia; 1993.

Brasil. Ministério da Saúde. A questão dos recursos humanos nas Conferências Nacionais de Saúde (1941/1992). Cad. RH Saúde 1993; 1(1).

Brasil. Ministério da Saúde. Formação superior em saúde: tendências da graduação no período 1985/1991. Cad. RH Saúde 1993; 1(2).

Carvalho GI. É possivel ter eficiência na gestão dos hospitais públicos: basta querer. Consultório Médico 1994.

Centro Brasileiro De Estudos De Saúde (CEBES). Municipalização das ações e serviços de saúde: a ousadia de cumprir e fazer cumprir a Lei. In: Descentralização do SUS:prioridade do MS. Saúde em Debate 1993; (38):417.

Cunha RE. Os caminhos da municipalização da saúde no Brasil. Espaço para a Saúde $1994 ; 3(3): 7-9$.

Cunha SPP, et al. I. Relato das experiências - Niterói - Rio de Janeiro. Espaço para a Saúde $1994 ; 3(3): 25-9$. 
Cyrino APP, et al. Perspectivas da descentralização e municipalização no Estado de São Paulo. Saúde em Debate 1990; (29):37-42.

Ferraz SMT. Municipalização dos serviços de saúde: formação de uma estratégia. Rev. Paul. Hosp. 1985; 33(11/12):272-5.

Figueira LNT; Jacomo YA. Perfil municipal de saúde de Ferraz de Vasconcelos. São Paulo, 1997. (Relatório Técnico)

Fleury S. Equidade e reforma sanitária: Brasil. Saúde em Debate 1994; (43):44-52.

Goulart FA. de A. Risco ou oportunidade? O momento presente da municipalização da saúde no Brasil. Espaço para a Saúde 1994; 3(3).

Gutierrez PR. Municipalização: uma proposta metodológica para implantação de vigilância à saúde do trabalhador. Saúde em Debate 1992; (37):51-5.

Hartz ZMA. Avaliação em Saúde: dos modelos conceituais à prática na análise da implantação de programas. Rio de Janeiro: Editora Fiocruz; 1997.

Ibañez N. Municipalização e sistema local de saúde: estudo de experiências municipais na implantação do Sistema Único de Saúde. 
São Paulo, 1994. [Tese para Concurso de Livre Docência - Faculdade de Saúde Pública da Universidade de São Paulo].

Jacomo YA. A assistência primária de saúde na municipalização. Rev. Paul. Hosp. $1995 ; 42(1): 12-5$.

Lima RCD. Recursos humanos em saúde: principais tendências na construção de um "novo" modelo assistencial: o SUS. São Paulo,1994.

Magalhães LB. A prática dos enfermeiros em postos de saúde municipais no Paraná, sua relação com a formação profissional e a organização dos serviços. São Paulo, [Tese de doutorado - Faculdade de Saúde Pública da Universidade de São Paulo].

Meira AR. Sociedade e saúde: uma introdução às noções de ciências sociais aplicada à saúde. Campo Grande: Oesp Gráfica S.A.; 1997.

Miola J, Misoczky MC. Comentários sobre o documento municipalização e serviços de saúde: a ousadia de cumprir e fazer cumprir a lei. Saúde em Debate 1993; (38):41-3.

Mishima SM, et al. Agentes comunitários de saúde: bom para o Ceará ... bom para o Brasil? Saúde em Debate 1992; (37):70-5.

Mishima SM. Recursos humanos na implantação das ações integradas de saúde no municipio de Ribeirão Preto: visão da equipe de enfermagem. Cad. Saúde Públ. 1990; 6(1):40-9. 
Misoczky MC. Distrito sanitário: desafio de descentralização com democracia. Saúde em Debate 1991; (33):54-60.

Organizacion Panamericana De La Salud. Conferencia panamericana sobre planificación de recursos humanos en salud. Ottawa: Canadá, 1973.

Pires D. Hegemonia médica na saúde e a enfermagem. São Paulo: Cortez; 1989.

Queirós AA. Ser enfermeiro (a) em cuidados de saúde primários algumas propostas de reflexão. 1990.

Santana JP. Municipalização da saúde: desafios para a cooperação técnica. Saúde em Debate 1990; (30):59-60.

Santos NR. O Sistema Único de Saúde: realizando a utopia sem perder a utopia. Saúde em Debate 1994; (43):64-70.

São Paulo. Secretaria De Estado Da Saúde. Código de saúde do Estado de São Paulo. 1995.

Schraiber Lb. Programação em Saúde hoje. Saúde em Debate - Série Didática. Editora HUCITEC; 1990. 
Teixeira CF. Formação de recursos humanos para o SUS: desafios na perspectiva da mudança do modelo de gestão e atenção à saúde. Saúde em Debate 1993; (41):20-3.

Teixeira CF. Municipalização da saúde: os caminhos do labirinto. Saúde em Debate 1991; (33):27-32. 


\section{ANEXO 1}

\section{IDENTIFICACÃO DA UNIDADE BÁSICA DE SAÚDE}

MUNICÍPIO:

DATA:

\section{Caracterizacão da Unidade}

- Nome da UBS:

- Bairro:

- Data de início de Funcionamento:

- Horário de Funcionamento:

\section{Atividades Desenvolvidas na UBS:}

- Especialidades médicas: - pediatria ( ) - clínica ( ) - G.O. ( )

- Outros

\section{Atividades de Enfermagem}

- imunização

- curativos:

- aplicação de medicamentos: - medicações ( ) - inalações ( )

- coleta de material:

- suplementação alimentar:

- esterilização de material:

- pré-consulta:

- pós-consulta:

- Atividades educativas em grupo:

- visita domiciliária:

- outras atividades: 


\section{Outras especialidades de profissionais não médicos:}

- odontologia

- psicologia

- fonoaudiologia

- fisioterapia

- assistente social

- outros profissionais:

\section{Recursos Humanos da UBS:}

- médicos: - pediatria - clínico - G.O. - Outros

- dentistas:

- enfermeiros:

- auxiliare de enfermagem:

- atendente de enfermagem ( se ainda houver):

- auxiliar odontológico:

- serventes:

- vigias:

- escriturários:

- outros: 


\section{ANEXO 2}

\section{ENFERMEIRO}

\section{IDENTIFICAÇÃO:}

- Data: / / Nome da Instituição:

- Sexo: ( ) Masculino ( ) Feminino

- Idade:

- Qual é o seu cargo ou função na Instituição?

- Possui alguma habilitação ou especialização em sua formação? Caso sim qual e em qual Instituição obteve o título.

- Há quanto tempo trabalha nesta Instituição?

- Há quanto tempo está neste cargo ou função?

- Quais são as suas funções e atividades rotineiras nesta Unidade?

- Quais as atividades que você dispensa maior tempo? Administrativa ou Assistencial? Porque?

- Você participa das decisões políticas em nivel local?

\section{SOBRE O SISTEMA ÚNICO DE SAÚDE - SUS}

1. O que você entende por SUS?

2. O que mudou na Unidade com a implantação do SUS na área da saúde?

3. Aponte os pontos positivos, se houver, que ocorreram na área da saúde após a implantação do SUS. 
4. Aponte os pontos negativos, se houver, que ocorreram na área da saúde após a implantação do SUS.

5. Para você qual é o papel do Conselho Municipal de Saúde (CMS)?

6. Existem representantes desta comunidade no CMS?

7. Existem representantes dos servidores da área da saúde desta Unidade no CMS, sabe como foram escolhidos?

\section{SOBRE OS RECURSOS HUMANOS}

8. Quantos funcionários da equipe de enfermagem trabalham nesta Unidade?

9. Você considera suficiente? Porque?

10. Quais os principais problemas que você apontaria em termos de Recursos Humanos nesta Unidade?

11. Após a implantação do SUS, houve alguma mudança em relação aos recursos humanos da Unidade em que trabalha?(qualitativa e quantitativa)

12. A sua Instituição oferece condições de desenvolvimento de recursos humanos? (cursos, treinamentos, estágios) Caso sim, para quem?

\section{SOBRE A UNIDADE BÁSICA DE SAÚDE}

13. Comente sobre o espaço físico desta Unidade.

14. Comente sobre os equipamentos desta Unidade.

15. Comente sobre os recursos técnicos desta Unidade.

16. De maneira geral como você recebe as informações, a respeito das decisões da Secretaria Municipal de Saúde com relação a sua Unidade? (Reuniões periódicas, cartas/ofícios/impressos, relatórios, telefonemas) 
17. Você considera que há obstáculos para o bom funcionamento da Unidade? Caso sim, o que considera obstáculo.

18. Desenvolve algum Programa junto à comunidade?

19. O serviço tem área de abrangência definida? Qual a sua opinião sobre a área de abrangência desta Unidade?

20. Qual o critério para o acesso dos usuários nesta Unidade?

21. Este serviço realiza atividades educativas? Quais? Quem realiza? 


\section{ANEXO 3}

\section{AUXILIAR DE ENFERMAGEM}

\section{IDENTIFICAÇÃO:}

- Data: / / Nome da Instituição:

- Idade do funcionário:

- Sexo: $F($ ) $M()$

- Tempo em que trabalha na Instituição como auxiliar de enfermagem:

\section{SOBRE O SEU TRABALHO NA UNIDADE:}

1. Quais são as atividade que você desenvolve na Unidade?

2. Você gosta de trabalhar nesta Unidade de saúde? Porque?

3. Quais fatores no serviço facilitam o seu trabalho?

4. Quais fatores no serviço dificultam o seu trabalho?

5. Você teria sugestões para melhorar os serviços prestados por esta unidade?

6. Você teria sugestões para melhorar os serviços de saúde prestados neste município?

\section{SOBRE OS RECURSOS HUMANOS DA UNIDADE}

7. O que você acha do número de funcionários no serviço onde você trabalha? Justifique.

8. Existe alguma atividade de reciclagem ou educação continuada para os funcionários desta Unidade?

9. Quais os principais problemas que você apontaria em termos de Recursos Humanos nesta Unidade? 


\section{SOBRE O SISTEMA ÚNICO DE SAÚDE - SUS}

10. O que você entende por SUS?

11. Houve alguma mudança, na área da saúde após a implantação do SUS?

12. Aponte os pontos positivos, se houver, que ocorreram na área da saúde após a implantação do SUS.

13. Aponte os pontos negativos, se houver, que ocorreram na área da saúde após a implantação do SUS.

\section{SOBRE A UNIDADE BÁSICA DE SAÚDE}

14. Existe algum tipo de divulgação dos serviços que a Unidade presta?

15. Se existe de que forma ela é feita?

16. Esta Unidade de saúde encaminha pacientes para outros serviços?

17. De uma forma geral, quais são os serviços para os quais os pacientes são encaminhados?

18. Comente sobre o espaço físico desta Unidade.

19. Comente sobre os equipamentos desta Unidade.

20. Comente sobre os recursos técnicos desta Unidade. 


\section{ANEXO 4}

\section{D.O.U. 26/05/98 - PÁGINAS 60 e 61 MINISTÉRIO DA SAÚDE}

PORTARIA Nº 2.553, DE 4 DE MAIO DE 1998

O Ministro de Estado da Saúde, no uso de suas atribuições, considerando o preconizado na Norma Operacional Básica do Sistema Único de Saúde - NOB SUS 01/96 e a decisão da Comissão Intergestores Tripartite - CIT, em reunião ordinária de 19 de março de 1998, resolve:

Art. $1^{\circ}$ - Habilitar os municípios dos Estados de São Paulo, conforme a relação anexa, na condição de Gestão Plena do Sistema Municipal e publicar os respectivos valores anuais dos Tetos Financeiros confirmados pela Comissão Intergestores Bipartite.

Parágrafo Único - Os municípios relacionados nesta Portaria farão jus à parcela mensal correspondente a $1 / 12$ (um doze avos) dos tetos financeiros publicados, com vigência a partir de $1^{\circ}$ de maio de 1998.

Art.2 - Considerar os referidos municípios qualificados para receberem os recursos relativos ao incentivo às Ações Básicas de Vigilância Sanitária no valor de $\mathrm{R} \$ 0,25$ (vinte e cinco centavos) por habitante ao ano.

Parágrafo Único - Os municipios farão jus à parcela mensal correspondente a $1 / 12$ (um doze avos) do valor referido neste artigo.

Art. $3^{\circ}$ - O Fundo Nacional de Saúde adotará as medidas necessárias para a transferência, regular e automática, dos valores mensais para os fundos municipais de saúde correspondentes.

Art.4 - Esta Portaria entrará em vigor na data da sua publicação.

José Serra

\section{ANEXO}

Plena do Sistema Municipal

São Paulo

\begin{tabular}{|c|l|l|}
\hline CODIGO & MUNICÍPIO & PAB FIXO (R\$) \\
\hline 355280 & Taboão da Serra & $4.585 .493,10$ \\
\hline
\end{tabular}




\title{
ANEXO 5
}

\author{
D.O.U. 06/01/99 - PÁGINA 11 \\ MINISTÉRIO DA SAÚDE
}

\section{PORTARIA N 4, DE 5 DE JANEIRO DE 1999}

O Ministro de Estado da Saúde, Interino, no uso de suas atribuições, e considerando o preconizado na Norma Operacional Básica do Sistema Único de Saúde - NOB SUS 01/96 e a decisão da Comissão Intergestores Tripartite - CIT, em reunião ordinária de 15 de dezembro de 1998, resolve:

Art. $1^{\circ}$ - Habilitar os municípios dos Estados de Amapá, Ceará, Goiás, Maranhão, Minas Gerais, Pará, Paraíba, Piaui, Rio de Janeiro, Rio Grande do Sul, Santa Catarina e São Paulo conforme o anexo desta Portaria, na condição de Gestão Plena da Atenção Básica e publicar os respectivos valores financeiros relativos à parte fixa do Piso da Atenção Básica - PAB.

Parágrafo Único - Os municípios relacionados nesta Portaria farão jus à parcela mensal correspondente a 1/12 (um doze avos) dos valores publicados, com vigência a partir de $1^{\circ}$ de janeiro de 1999.

Art.2 $^{\circ}$ - Considerar os referidos municipios qualificados para receberem os recursos relativos ao incentivo às Ações Básicas de Vigilância Sanitária no valor de $\mathrm{R} \$ 0,25$ (vinte e cinco centavos) por habitante ao ano.

Parágrafo Único - Os municípios farão jus à parcela mensal correspondente a 1/12 (um doze avos) do valor referido neste artigo.

Art. $3^{\circ}$ - O Fundo Nacional de Saúde adotará as medidas necessárias para a transferência regular e automática, dos valores mensais para os fundos municipais de saúde correspondentes.

Art.4 - Esta Portaria entrará em vigor na data da sua publicação, com efeitos financeiros vigentes a partir de $1^{\circ}$ de janeiro de 1999.

\section{Jarbas Negri}

\section{ANEXO}

Plena de Atenção Básica

São Paulo

\begin{tabular}{|l|l|l} 
CODIGO & MUNICIPIO & PAB FIXO (R\$) \\
\hline
\end{tabular}

\begin{tabular}{|l|l|l}
\hline 351570 & Ferraz de Vasconcelos & $1.284 .040,00$ \\
\hline
\end{tabular}




\title{
ANEXO 6
}

\section{MINISTÉRIO DA SAÚDE}

\author{
Portaria n 1886 , de 18 de dezembro de 1997
}

Publicada no DOU n ${ }^{\circ} 247$, de 22.12.97,seção

Aprova as Normas e Diretrizes do Programa de Agentes Comunitários de Saúde e do Programa de Saúde da Família

O Ministro de Estado da Saúde, no uso de suas atribuições e, considerando que

O Ministério da Saúde estabeleceu no seu Plano de Ações e Metas priorizar os Programas de Agentes Comunitários de Saúde e de Saúde da Família, estimulando a sua expansão;

O Ministério da Saúde reconhece no Programa de Agentes Comunitários de Saúde e no Programa de Saúde da Família importante estratégia para contribuir no aprimoramento e na consolidação do Sistema Único de Saúde, a partir da reorientação da assistência ambulatorial e domiciliar, RESOLVE:

Art. $1^{\circ}$ - Aprovar as Normas e Diretrizes do Programa de Agentes Comunitários de Saúde e do Programa de Saúde da Família, nos termos dos Anexos I e II desta Portaria, com vistas a regulamentar a implantação e operacionalização dos referidos Programas.

Art. $2^{\circ}$ - Esta portaria entrará em vigor na data de sua publicação.

\section{CARLOS CÉSAR DE ALBUQUERQUE}




\section{ANEXO I \\ NORMAS E DIRETRIZES DO PROGRAMA DE AGENTES COMUNITÁRIOS DE SAÚDE - PACS RESPONSABILIDADES DO MINISTÉRIO DA SAÚDE}

1. Ao Ministério da Saúde, no âmbito do PACS, cabe:

1.1. Contribuir para a reorientação do modelo assistencial através do estímulo à adoção da estratégia de agentes comunitários de saúde pelos serviços municipais de saúde.

1.2. Definir normas e diretrizes para a implantação do programa.

1.3. Garantir fontes de recursos federais para compor o financiamento tripartite do programa.

1.4. Definir mecanismo de alocação de recursos federais para a implantação e a manutenção do programa, de acordo com os princípios do SUS.

1.5. Definir prioridades para a alocação da parcela de recursos federais ao programa;

Regulamentar e regular o cadastramento dos ACS e enfermeiros instrutores/supervisores no SIA/SUS.

1.6. Prestar assessoria técnica aos estados e municípios para o processo de implantação e de gerenciamento do programa.

1.7. Disponibilizar instrumentos técnicos e pedagógicos facilitadores ao processo de capacitação e educação permanente dos ACS e dos enfermeiros instrutoressupervisores;

1.8. Disponibilizar o Sistema de Informação da Atenção Básica - SIAB, ou transitoriamente o Sistema de Informação do PACS - SIPACS como instrumento para monitorar as ações desenvolvidas pelos ACS.

1.9. Assessorar estados e municípios na implantação do Sistema de Informação.

1.10. Consolidar e analisar os dados de interesse nacional gerados pelo sistema de informação e divulgar os resultados obtidos.

1.11. Controlar o cumprimento, pelos estados e municípios, da alimentação do banco de dados do sistema de informação.

1.12. Identificar recursos técnicos e científicos para o processo de controle e, avaliação dos resultados e do impacto das ações do PACS. 


\section{SAÚDE DA FAMÍLIA}

1.13. Articular e promover o intercâmbio de experiências, para aperfeiçoar disseminar tecnologias e conhecimentos voltados à atenção primária à saúde.

1.14.Identificar e viabilizar parcerias com organismos internacionais de apoio, com organizações governamentais, não governamentais e do setor privado.

\section{RESPONSABILIDADES DA SECRETARIA ESTADUAL DE SAÚDE}

2. No âmbito das Unidades da Federação a coordenação do PACS, de acordo com o princípio de gestão descentralizada do Sistema Único de Saúde, está sob a responsabilidade das Secretarias Estaduais de Saúde. Compete à esta instância definir, dentro de sua estrutura administrativa, o setor que responderá pelo processo de coordenação do programa e que exercerá o papel de interlocutor com o nível de gerenciamento nacional.

3. Às Secretarias Estaduais de Saúde, no âmbito do PACS, cabe:

3.1. Contribuir para a reorientação do modelo assistencial através do estímulo à adoção da estratégia de agentes comunitários de saúde pelos serviços municipais de saúde.

3.2. Estabelecer, em conjunto com a instância de gerenciamento nacional do programa, as normas e as diretrizes do programa.

3.3. Definir os critérios de priorização de municípios para implantação do programa.

3.4. Definir estratégias de implantação e/ou implementação do programa.

3.5. Garantir fontes de recursos estaduais para compor o financiamento tripartite do programa.

3. 6. Definir mecanismo de alocação de recursos que compõem o teto financeiro do Estado para a implantação e a manutenção do programa.

3.7. Definir prioridades para a alocação da parcela de recursos estaduais ao programa.

3.8. Pactuar com o Conselho Estadual de Saúde e com a Comissão Intergestores Bipartite os requisitos específicos para a implantação do programa.

3.9. Regular o cadastramento dos ACS e enfermeiros instrutores/supervisores no SIA/SUS

3.10. Prestar assessoria técnica aos municípios em todo o processo de implantação, monitoramento e de gerenciamento do programa.

3.11. Disponibilizar aos municípios instrumentos técnicos e pedagógicos facilitadores ao processo de formação e educação permanente dos ACS.

3.12. Capacitar e garantir processo de educação permanente aos enfermeiros instrutores-supervisores dos ACS; 
3.13. Assessorar os municípios para implantação do Sistema de Informação da Atenção Básica - SIAB, ou transitoriamente o Sistema de Informação do PACS SIPACS como instrumento para monitorar as ações desenvolvidas pelos ACS;

3.14. Consolidar e analisar os dados de interesse estadual gerados pelo sistema de informação e divulgar os resultados obtidos.

3.15. Controlar o cumprimento, pelos municípios, da alimentação do banco de dados do sistema de informação

3.16. Identificar recursos técnicos e científicos para o processo de controle e avaliação dos resultados das ações do PACS no âmbito do estado.

3.17. Promover o intercâmbio de experiência entre os diversos municípios, objetivando disseminar tecnologias e conhecimentos voltados à melhoria do atendimento primário à saúde.

3.18. Identificar e viabilizar parcerias com organismos internacionais de apoio, com organizações governamentais, não governamentais e do setor privado para fortalecimento do programa no âmbito do estado.

\section{RESPONSABILIDADES DO MUNICÍPIO}

4. O município deve cumprir os seguintes REQUISITOS para sua inserção ao Programa de Agentes Comunitários de Saúde:

4.1. Apresentar ata de reunião do Conselho Municipal de Saúde onde está aprovada a implantação do programa.

4.2. Definir Unidade Básica de Saúde para referência c cadastramento dos Agentes Comunitários de Saúde no SIA/SUS.

4.3. Comprovar a existência de Fundo Municipal de Saúde ou conta especial para a saúde.

4.4. Garantir a existência de profissional(ais) enfermeiro(s), com dedicação integral na(s) unidade(s) básica(s) de referência, onde no âmbito de suas atribuições exercerão a função de instrutor supervisor, na proporção de no máximo 30 Agentes Comunitários de Saúde para 01 enfermeiro.

5. A adesão ao PACS deve ser solicitada, pelo município, à Secretaria Estadual de Saúde.

\section{PRERROGATIVAS:}

6.1. O Ministério da Saúde repassará recursos financeiros de incentivo, proporcionais à população assistida pelos Agentes Comunitários de Saúde, de acordo com critérios e prioridades definidos e pactuados na Comissão Intergestores Tripartite. 
6.2. As Secretarias Estaduais definirão a forma de apoio no âmbito de suas competências.

7. No âmbito do Programa de Agentes Comunitários de Saúde, ao município cabe:

7.1. Conduzir a implantação e a operacionalização do programa como ação integrada e subordinada ao serviço municipal de saúde.

7.2. Inserir o PACS nas ações estratégicas do Plano Municipal de Saúde garantir infra-estrutura de funcionamento da(s) unidade(s) básica(s) de referência dos ACS.

7.3. Inserir as atividades do programa na programação fisico financeira ambulatorial do município, com definição de contrapartida de recursos municipais.

7.4. Definir áreas geográficas para implantação do programa, priorizando aquelas onde as familias estão mais expostas aos riscos de adoecer e morrer.

7.5. Recrutar os agentes comunitários de saúde através de processo seletivo, segundo as normas e diretrizes básicas do programa.

7.6. Contratar e remunerar os ACS e o(s) enfermeiro(s) instrutor(es) / supervisor(es); Garantir as condições necessárias para o processo de capacitação e educação permanente dos ACS.

7.7 Garantir as condições necessárias para o processo de capacitação e educação permanente dos enfermeiros instrutores supervisores, com apoio da Secretaria Estadual de Saúde.

7.8. Implantar o Sistema de Informação da Atenção Básica - SIAB, ou transitoriamente o Sistema de Informação de Programa de Agentes Comunitários de Saúde - SIPACS, cumprindo o fluxo estabelecido para alimentação dos bancos de dados regional e estadual.

7.9. Utilizar os dados gerados pelo sistema de informação para definição de atividades prioritárias dos ACS no processo de programação e planejamento das ações das unidades básicas de referência.

7. 10. Apresentar sistematicamente a análise dos dados do sistema de informação aos conselhos locais e municipal de saúde.

7.11.Viabilizar equipamentos necessários para a informatização do sistema de informação.

\section{DIRETRIZES OPERACIONAIS}

8. Na operacionalização do Programa deverão ser observadas as seguintes diretrizes:

8.1. O Agente Comunitário de Saúde-ACS deve trabalhar com adscrição de famílias em base geográfica definida. 


\section{SAÚDE DA FAMÍLIA}

8.2. Um ACS é responsável pelo acompanhamento de, no máximo, 150 famílias ou 750 pessoas

8.3. O recrutamento do Agente Comunitário de Saúde deve se dar através de processo seletivo,no próprio município, com assessoria da Secretaria Estadual de Saúde.

8.4. São considerados requisitos para o ACS: ser morador da área onde exercerá suas atividades há pelo menos dois anos, saber ler e escrever, ser maior de dezoito anos e ter disponibilidade de tempo integral para exercer suas atividades.

8.5. O Agente Comunitário de Saúde deve desenvolver atividades de prevenção das doenças e promoção da saúde, através de visitas domiciliares e de ações educativas individuais e coletivas, nos domicílios e na Comunidade, sob supervisão e acompanhamento do enfermeiro Instrutor-Supervisor lotado na unidade básica de saúde da sua referência.

8.6. É vedado ao ACS desenvolver atividades típicas do serviço interno das unidades básicas de saúde de sua referência.

8.7. A capacitação do Agente Comunitário de Saúde deve ocorrer em serviço, de forma continuada, gradual e permanente, sob a responsabilidade do InstrutorSupervisor, com a participação e colaboração de outros profissionais do serviço local de saúde.

8.8. O ACS deve ser capacitado para prestar assistência a todos os membros das famílias acompanhadas, de acordo com as suas atribuições e competências.

8.9. O conteúdo das capacitações deve considerar as prioridades definidas pelo elenco de problemas identificados em cada território de trabalho.

8.10. A substituição de um ACS por suplente classificado no processo seletivo poderá ocorrer em situações onde o ACS: deixa de residir na área de sua atuação; assume outra atividade que comprometa a carga horária necessária para desempenho de suas atividades; não cumpre os compromissos e atribuições assumidas; gera conflitos ou rejeição junto a sua comunidade; o próprio ACS, por motivos particulares, requeira seu afastamento.

8.11. Em caso de impasse na substituição de um ACS, a situação deve ser submetida ao conselho local ou municipal de saúde.

8.12. O monitoramento e avaliação das ações desenvolvidas pelo Programa deverá ser realizado pelo Sistema de Informação da Atenção Básica - SIAB, ou transitoriamente pelo Sistema de Informação do Programa de Agentes Comunitários de Saúde SIPACS ou ainda por outro sistema de informação implantado pelo município, desde que alimente a base de dados do sistema preconizado ao Programa pela Ministério da Saúde (SIAB ou SIPACS). 


\section{SAÚDE DA FAMÍLIA}

8.13. A não alimentação do Sistema de Informação por um período de 02 (dois) meses consecutivos ou 03 (três) meses alternados durante o ano, implicará na suspensão do cadastramento do programa.

8.14. São consideradas atribuições básicas dos ACS, nas suas áreas territoriais de abrangência:

8.14.1. realização do cadastramento das familias;

8.14.2. participação na realização do diagnóstico demográfico e na definição do 8.14.3. perfil sócio econômico da comunidade, na identificação de traços culturais e religiosos das familias e da comunidade, na descrição do perfil do meio ambiente da área de abrangência, na realização do levantamento das condições de saneamento básico e realização do mapeamento da sua área de abrangência;

8.14.4. realização do acompanhamento das micro-áreas de risco;

8.14.5. realização da programação das visitas domiciliares, elevando a sua frequência nos domicílios que apresentam situações que requeiram atenção especial;

8.14.6. atualização das fichas de cadastramento dos componentes das famílias; execução da vigilância de crianças menores de 01 ano consideradas em situação de risco ;

8.14.7. acompanhamento do crescimento e desenvolvimento das crianças de 0 a 5 anos;

8.14.8. promoção da imunização de rotina às crianças e gestantes, encaminhando-as ao serviço de referência ou criando alternativas de facilitação de acesso;

8.14.9. promoção do aleitamento materno exclusivo;

8.14.10. monitoramento das diarréias e promoção da reidratação oral;

monitoramento das infecções respiratórias agudas, com identificação de sinais de risco e encaminhamento dos casos suspeitos de pneumonia ao serviço de saúde de referência;

8.14.11 monitoramento das dermatoses e parasitoses em crianças;

8.14.12. orientação dos adolescentes e familiares na prevenção de DST/AIDS, gravidez precoce e uso de drogas;

8.14.13 identificação e encaminhamento das gestantes para o serviço de prénatal na unidade de saúde de referência;

8.14.14. realização de visitas domiciliares periódicas para monitoramento das gestantes, priorizando atenção nos aspectos de: desenvolvimento da gestação; 8.14.15 seguimento do pré-natal; sinais e sintomas de risco na gestação; 
nutrição; 8.14. incentivo e preparo para o aleitamento materno; preparo para o parto;

8.14.16 atenção e cuidados ao recém nascido; cuidados no puerpério;

8.14.17 monitoramento dos recém nascidos e das puérperas;

8.14.18. realização de ações educativas para a prevenção do câncer cérvicouterino e de mama, encaminhando as mulheres em idade fertil para realização dos exames periódicos nas unidades de saúde da referência;

8.14.19. realização de ações educativas sobre métodos de planejamento familiar;

8.14.20. realização de ações educativas referentes ao climatério;

8.14.21. realização de atividades de educação nutricional nas familias e na comunidade;

8.14.22. realização de atividades de educação em saúde bucal na familia, com ênfase no grupo infantil.

8.14.23. busca ativa das doenças infecto-contagiosas;

8.14.24. apoio a inquéritos epidemiológicos ou investigação de surtos ou ocorrência de doenças de notificação compulsória;

8.14.25. supervisão dos eventuais componentes da família em tratamento domiciliar e dos pacientes com tuberculose, hanseníase, hipertensão, diabetes e outras doenças crônicas;

8.14.26. realização de atividades de prevenção e promoção da saúde do idoso;

8.14.27. identificação dos portadores de deficiência psicofisica com orientação aos familiares para o apoio necessário no próprio domicílio;

8.14.28. incentivo à comunidade na aceitação e inserção social dos portadores de deficiência psicofísica;

8.14.29. orientação às famílias e à comunidade para a prevenção e o controle das doenças endêmicas;

8.14.30. realização de ações educativas para preservação do meio ambiente;

8.14.31. realização de ações para a sensibilização das famílias e da comunidade para abordagem dos direitos humanos;

8.14.32. estimulação da participação comunitária para ações que visem a melhoria da qualidade de vida da comunidade;

8.14.33. outras ações e atividades a serem definidas de acordo com prioridades locais.

8.15. São consideradas atribuições básicas dos enfermeiros instrutores/supervisores: 


\section{SAÚDE DA FAMÍLIA}

8.15.1. planejar e coordenar a capacitação e educação permanente dos ACS, executando-a com participação dos demais membros da equipe de profissionais do serviço local de saúde;

8.15.2. coordenar, acompanhar, supervisionar e avaliar sistematicamente o trabalho dos ACS;

8.15.3. reorganizar e readequar, se necessário, o mapeamento das áreas de implantação do programa após a seleção dos ACS, de acordo com a dispersão demográfica de cada área e respeitando o parâmetro do número máximo de familias por ACS ;

8.15.4. coordenar a acompanhar a realização do cadastramento das famílias;

8.15.5. realizar, com demais profissionais da unidade básica de saúde, o diagnóstico demográfico e a definição do perfil sócio econômico da comunidade, a identificação de traços culturais e religiosos das famílias e da comunidade, a descrição do perfil do meio ambiente da área de abrangência, a realização do levantamento das condições de saneamento básico e realização do mapeamento da área de abrangência dos ACS sob sua responsabilidade;

8.15.6. coordenar a identificação das micro-áreas de risco para priorização das ações dos ACS ;

8.15.7. coordenar a programação das visitas domiciliares a serem realizadas pelos ACS, realizando acompanhamento e supervisão periódicas;

8.15.8. coordenar a atualização das fichas de cadastramento das famílias;

8.15.9. coordenar e supervisionar a vigilância de crianças menores de 01 ano consideradas em situação de risco;

8.15.10. executar, no nível de suas competências, ações de assistência básica na unidade básica de saúde, no domicílio e na comunidade;

8.15.11. participar do processo de capacitação e educação permanente técnica e gerencial junto às coordenações regional e estadual do programa;

8.15.12 consolidar, analisar e divulgar mensalmente os dados gerados pelo sistema de informação do programa;

8.15.13. participar do processo de programação e planejamento das ações e da organização do processo de trabalho da unidade básica de saúde, considerando a análise das informações geradas pelos ACS;

8.15.14. definir, juntamente com a equipe da unidade básica de saúde, as ações e atribuições prioritárias dos ACS para enfrentamento dos problemas identificados;

alimentar o fluxo do sistema de informação aos níveis regional e estadual, nos prazos estipulados; 


\title{
SAÚDE DA FAMÍLIA
}

\begin{abstract}
8.15.15. tomar as medidas necessárias, junto à secretaria municipal de saúde $\mathrm{e}$ conselho municipal de saúde, quando da necessidade de substituição de um ACS;

8.15.16. outras ações e atividades a serem definidas de acordo com prioridades locais.
\end{abstract}

9. O não cumprimento das normas e diretrizes do programa implicará na suspensão da alocação de recursos federais para o seu financiamento.

\section{ANEXO II \\ NORMAS E DIRETRIZES DO PROGRAMA DE SAÚdE DA FAMÍlIA - PSF RESPONSABILIDADES DO MINISTÉRIO DA SAÚDE}

1. Ao Ministério da Saúde, no âmbito do PSF, cabe:

1.1. Contribuir para a reorientação do modelo assistencial através do estímulo à adoção da estratégia de saúde da família pelos serviços municipais de saúde.

1.2. Estabelecer normas e diretrizes para a implantação do programa.

Garantir fontes de recursos federais para compor o financiamento tripartite do programa.

1.3. Definir mecanismo de alocação de recursos federais para a implantação e a manutenção das unidades de saúde da família, de acordo com os princípios do SUS.

1.4. Definir prioridades para a alocação da parcela de recursos federais ao programa.

1.5. Negociar na Comissão Intergestora Tripartite os requisitos específicos e prerrogativas para implantação e ou implementação da estratégia de saúde da família.

1.6. Regulamentar e regular o cadastramento das unidades de saúde da família no SIA/SUS.

1.7. Prestar assessoria técnica aos estados e municípios para o processo de implantação e de gerenciamento do programa.

1.8. Promover a articulação entre as instituições de ensino superior e as instituições de serviço para capacitação, formação e educação permanente dos recursos humanos necessários ao modelo de saúde da família.

1.9. Assessorar os Pólos de Capacitação, formação e educação permanente para as equipes de saúde da família no que se refere a elaboração, acompanhamento e avaliação de seus objetivos e ações.

1.10. Articular com as instituições de ensino superior para a iniciativa de introduzir inovações curriculares nos cursos de graduação e ou implantação de cursos de especialização ou outras formas de cursos de pós-graduação "sensu latu". 


\section{SAÚDE DA FAMÍLIA}

1.11. Disponibilizar o Sistema de Informação da Atenção Básica - SIAB como instrumento para monitorar as ações desenvolvidas pelas unidades de saúde da família.

1.12. Assessorar estados e municípios na implantação do Sistema de Informação;

1.1.3 Consolidar e analisar os dados de interesse nacional gerados pelo sistema de informação, divulgando resultados obtidos.

1.14. Controlar o cumprimento, pelos estados e municípios, da alimentação do banco de dados do sistema de informação.

1.15. Identificar recursos técnicos e científicos para o processo de controle e avaliação dos resultados e do impacto das ações das unidades de saúde da família.

1.16. Contribuir para a criação de uma rede nacional / regional de intercâmbio de experiências no processo de produção de conhecimento em saúde da familia.

1.17. Promover articulações com outras instâncias da esfera federal a fim de garantir a consolidação da estratégia de saúde da familia;

Identificar e viabilizar parcerias com organismos internacionais de apoio, com organizações governamentais, não governamentais e do setor privado.

\section{RESPONSABILIDADES DA SECRETARIA ESTADUAL DE SAÚDE}

2. No âmbito das Unidades da Federação a coordenação do PSF, de acordo com o princípio de gestão descentralizada do Sistema Único de Saúde, está sob a responsabilidade das Secretarias Estaduais de Saúde. Compete à esta instância definir, dentro de sua estrutura administrativa, o setor que responderá pelo processo de coordenação do programa e que exercerá o papel de interlocutor com o nível de gerenciamento nacional.

3. Às Secretarias Estaduais de Saúde, no âmbito do PSF, cabe:

3.1. Contribuir para a reorientação do modelo assistencial através do estímulo à adoção da estratégia de saúde da família pelos serviços municipais de saúde.

3.2. Estabelecer, em conjunto com a instância de gerenciamento nacional do programa, as normas e as diretrizes do programa.

3.3. Definir estratégias de implantação e/ou implementação do programa.

3.4. Garantir fontes de recursos estaduais para compor o financiamento tripartite do programa.

3.5 Definir mecanismo de alocação de recursos que compoem o teto financeiro do Estado para a implantação e a manutenção do programa.

3.6. Definir prioridades para a alocação da parcela de recursos estaduais ao programa; 
3.7. Pactuar com o Conselho Estadual de Saúde e com a Comissão de Intergestores Bipartite os requisitos específicos e priorizações para a implantação do programa.

3.8. Cadastrar as unidades de saúde da família no SIA/SUS

3.9. Prestar assessoria técnica aos municípios em todo o processo de implantação, monitoramento e gerenciamento do programa.

3.10. Promover articulação com as instituições de ensino superior para capacitação, formação e educação permanente dos recursos humanos de saúde da família;

3.11. Integrar os Pólos de Capacitação, formação e educação permanente para as equipes de saúde da família no que se refere a elaboração, acompanhamento e avaliação de seus objetivos e ações;

3.12. Articular com as instituições de ensino superior para a iniciativa de introduzir inovações curriculares nos cursos de graduação e ou implantação de cursos de especialização ou outras formas de cursos de pós-graduação "sensu latu".

3.13. Assessorar os municípios na implantação do Sistema de Informação da Atenção Básica - SIAB, enquanto instrumento para monitorar as ações desenvolvidas pelas unidades de saúde da familia;

3.14. Consolidar e analisar os dados de interesse estadual gerados pelo sistema de informação e alimentar o banco de dados nacional.

3.15. Controlar o cumprimento, pelos municípios, da alimentação do banco de dados do sistema de informação

3.16. Identificar recursos técnicos e científicos para o processo de controle e avaliação dos resultados e do impacto das ações das unidades de saúde da família no âmbito do estado;

3.17. Participar de rede nacional / regional de intercâmbio de experiências no processo de produção de conhecimento em saúde da familia;

3.18. Promover intercâmbio de experiências entre os municípios de sua abrangência;

promover articulações com outras instâncias da esfera estadual, a fim de garantir a consolidação da estratégia de saúde a família;

3.19. Identificar e viabilizar parcerias com organismos internacionais de apoio, com organizações governamentais, não governamentais e do setor privado.

\section{RESPONSABILIDADES DO MUNICÍPIO}

4.1. Conduzir a implantação e a operacionalização do PSF como estratégia de reorientação das unidades básicas de saúde, no âmbito do sistema local de saúde.

4.2. Inserir o PSF nas ações estratégicas do Plano Municipal de Saúde.

4.3. Inserir as unidades de saúde da familia na programação físico financeira ambulatorial do município, com definição de contrapartida de recursos municipais. 
4.4. Eleger áreas para implantação das unidades de saúde da família, priorizando aquelas onde a população está mais exposta aos riscos sociais.

selecionar, contratar e remunerar os profissionais que integram as equipes de saúde da familia.

4.5. Garantir a capacitação e educação permanente da equipes de saúde da família, com apoio da secretaria estadual de saúde.

4.6. Monitorar e avaliar as ações desenvolvidas pelas unidades de saúde da família, através do Sistema de Informação da Atenção Básica - SIAB, ou por outro instrumento de monitoramento, desde que alimente a base de dados do sistema preconizado ao Programa pelo Ministério da Saúde (SIAB).

4.7. Utilizar os dados gerados pelo sistema de informação para definição de atividades prioritárias no processo de programação e planejamento das ações locais.

4.8. Apresentar sistematicamente a análise dos dados do sistema de informação e de outros mecanismos e/ou instrumentos de avaliação, aos conselhos locais e municipal de saúde.

4.9. Garantir a infra estrutura e os insumos necessários para resolutividade das unidades de saúde da família.

4.10. Garantir a inserção das unidades de saúde da família na rede de serviços de saúde, garantindo referência e contra-referência aos serviços de apoio diagnóstico, especialidades ambulatoriais, urgências/emergências e internação hospitalar.

\section{PROGRAMA}

\section{REQUISITOS PARA A INSERÇÃO DO MUNICÍPIO NO}

5. O município é o espaço de execução da estratégia de saúde da família enquanto projeto estruturante da atenção básica, portanto cabe a este nível definir os meios e condições operacionais para sua implantação.

6. O município deve cumprir os seguintes REQUISITOS para sua inserção ao Programa de Saúde da Família:

6.1. Estar habilitado em alguma forma de gestão segundo a NOB/SUS 01/96

6.2. Apresentar ata de reunião do Conselho Municipal de Saúde onde aprova-se a implantação do programa;

7. A adesão ao PSF deve ser solicitada, pelo município, à Secretaria Estadual de Saúde.

\section{PRERROGATIVAS}

8. São prerrogativas do município: 
8.1. O Ministério da Saúde repassará recursos financeiros de incentivo, proporcionais à população assistida pelas unidades de saúde da família, de acordo com critérios e prioridades definidos e pactuados na Comissão Intergestores Tripartite.

8.2. As Secretarias Estaduais definirão a forma de apoio no âmbito de suas competências.

\section{DIRETRIZES OPERACIONAIS DO PROGRAMA DE SAÚdE DA FAMÍLIA}

9. Aspectos que caracterizam a reorganização das práticas de trabalho nas unidades de saúde da familia:

9.1. Caráter substitutivo das práticas tradicionais das unidades básicas de saúde, complementariedade e hierarquização.

9.2. Adscrição de população/territorialização.

9.3. Programação e planejamento descentralizados.

9.4. Integralidade da assistência.

9.5. Abordagem multiprofissional.

9.6. Estímulo à ação intersetorial.

9.7. Estímulo à participação e controle social.

9.8. Educação permanente dos profissionais das equipes de saúde da família.

9.9. Adoção de instrumentos permanentes de acompanhamento e avaliação.

10. Caracterização das unidades de saúde da família:

10.1. Consiste em unidade ambulatorial pública de saúde destinada a realizar assistência contínua nas especialidades básicas, através de equipe multiprofissional. Desenvolve ações de promoção, prevenção, diagnóstico precoce, tratamento e reabilitação, características do nível primário de atenção, tendo como campos de intervenção o indivíduo, a família, o ambulatório, a comunidade e o meio ambiente.

10.2. Configura-se como o primeiro contato da população com o serviço local de saúde, onde se garanta resolutividade na sua coplexidade tecnológica, assegurando-se referência e contra-referência com os diferentes níveis do sistema quando é requerida maior complexidade para resolução dos problemas identificados.

10.3. Trabalha com definição de território de abrangência, que significa a área que está sob sua responsabilidade.

10.4. Pode atuar com uma ou mais equipes de profissionais, a depender da área de abrangência e do número de habitantes vinculados a esta unidade.

10.5. As equipes devem realizar o cadastramento das familias, com visita aos domicílios, segundo a definição territorial pré-estabelecida; 


\section{SAÚDE DA FAMÍLIA}

11. Caracterização das equipes de saúde da família:

11.1. Uma equipe de profissionais de saúde da família pode ser responsável, no âmbito de abrangência de uma unidade de saúde da família, por uma área onde resida, no máximo, 1000 (mil) famílias ou 4.500 (quatro mil e quinhentas) pessoas.

11.2. Recomenda-se que uma equipe de saúde da família deva ser composta mínimamente pelos seguintes profissionais: médico, enfermeiro, auxiliares de enfermagem e agentes comunitários de saúde (na proporção de um agente para, no máximo, 150 familias ou 750 pessoas).

11.3. Para efeito de incorporação dos incentivos financeiros do Ministério da Saúde, as equipes deverão atender aos seguintes parâmetros mínimos de composição:

11.3.1.Médico, enfermeiro, auxiliares de enfermagem e agentes comunitários de saúde (na proporção de 01 ACS para, no máximo, 150 familias ou 750 pessoas) ou

11.3.2. Médico, enfermeiro e auxiliares de enfermagem. 